\title{
INDONESIA'S PERSPECTIVE ON TOTAL OFFICIAL SUPPORT FOR SUSTAINABLE DEVELOPMENT (TOSSD)
}

Guillaume Delalande, Aussama Bejraoui, Melissa Li and Julia Benn
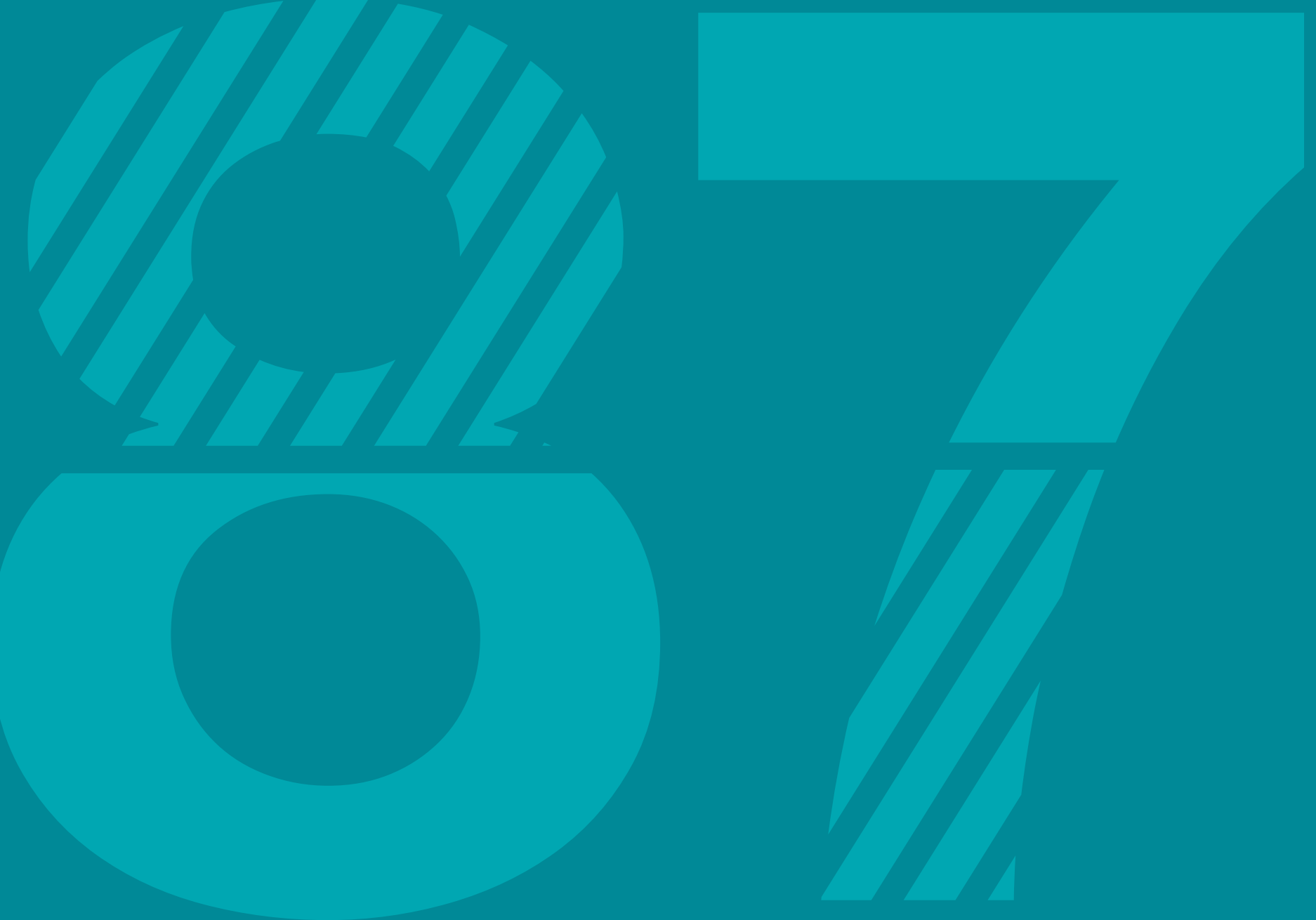

\section{OECD DEVELOPMENT CO-OPERATION WORKING PAPER 87}

Authorised for publication by Jorge Moreira da Silva, Director, Development Co-operation Directorate

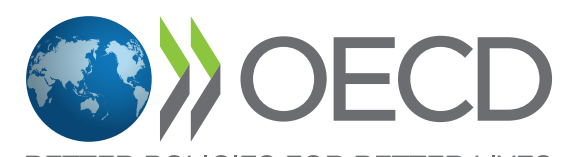





\section{Abstract}

This Working Paper presents the perspective of Indonesia on the concept of total official support for sustainable development (TOSSD), the extent of TOSSD resources provided by Indonesia and the capacity of the government to report on these resources.

Indonesia broadly supported TOSSD as a relevant measure for monitoring SDG implementation and proposed some adjustments to the TOSSD methodology.

Estimates for TOSSD provided by Indonesia in 2017 amount to USD 6376 million, with USD 16 million for Pillar I (cross-border flows to other developing countries) and USD 6360 million for Pillar II (contributions to international public goods). For Indonesia, activities recorded in TOSSD should not only be assessed in financial terms, but also in terms of their sustainable development impact.

This pilot study attests to Indonesia's strong capacity to report on TOSSD Pillar I, but finds that tracking could be improved for a wider range of resources. The country also has the capacity to report on Pillar II.

\section{Disclaimer}

OECD Working Papers do not represent the official views of the OECD or of its member countries. The opinions expressed and arguments employed are those of the authors.

This document was produced with the financial assistance of the European Union. The views expressed herein can in no way be taken to reflect the official opinion of the European Union.

Working Papers describe preliminary results or research in progress by the authors and are published to stimulate discussion on a broad range of issues on which the OECD works. Comments on the present Working Paper are welcomed and may be sent to dac.contact@oecd.org — the Development Co-operation Directorate, OECD, 2 rue André-Pascal, 75775 Paris Cedex 16, France.

Please cite this document as: Delalande G., A. Bejraoui, M. Li and J. Benn (2020),"Indonesia's perspective on Total Official Support for Sustainable Development (TOSSD)", OECD Development Co-operation Working Paper no. 87, OECD Publishing, Paris. 


\section{Acknowledgements}

The authors would like to thank the Government of Indonesia and particularly the Ministry of National Development Planning (Bappenas) for hosting and coordinating this TOSSD country pilot study. The authors would especially like to thank Ms. Amalia Adininggar Widyasanti, Head of the SDGs Secretariat, Ms. Tissa Riani and Ms. Chiquita Abidin for organising the in-country mission and supporting the authors in finalising the present report. The authors would also like to thank the OECD office in Jakarta for their valuable support during the in-country mission (Mr. Massimo Geloso Grosso and Ms. Yulianti Susilo).

The authors are grateful to all staff from the various ministries and all other institutions met during the country mission (cf. Annex A) for their valuable time and inputs.

The Government of Indonesia had the opportunity to comment on the present report before its publication. The report also benefited from helpful comments and inputs from the following colleagues of the OECD Development Co-operation Directorate: Kerri Elgar, Nadine Piefer-Söyler and Ashley Palmer.

Finally, the authors would like to gratefully acknowledge the financial assistance of the European Union for this country pilot study, which supports the work of the International TOSSD Task Force and allows for testing the various parameters and methodologies of TOSSD.

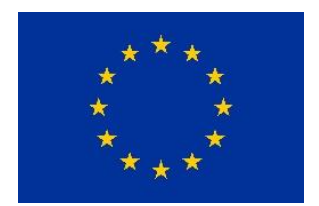

Co-Funded by

The European Union 


\section{Table of contents}

Abstract 3

Disclaimer 3

Acknowledgements $\quad 4$

Executive summary $\quad 8$

$\begin{array}{ll}\text { Part I. Main findings and recommendations } & 11\end{array}$

1. General findings related to TOSSD and the TOSSD methodology 12

1.1. The perspective of Indonesia on the TOSSD concept and methodology 12

1.2. Usefulness of the TOSSD concept for Indonesia 13

1.3. Assessment of the capacity of Indonesia to report on TOSSD 14

1.4. Estimated TOSSD flows for Indonesia as a provider of financing for sustainable

development $\quad 15$

2. Recommendations and next steps 17

2.1. Recommendations to the international TOSSD Task Force for adjusting the TOSSD framework

2.2. Recommendations to the government of Indonesia to enhance its capacity to collect and report data on financing for sustainable development

2.3. Next steps

Part II. Background information on TOSSD pilot studies and the context of Indonesia 20

3. Context and objectives of the country pilot study 21

3.1. The concept of TOSSD 21

3.2. The critical importance of engaging with partner countries and South-South co-operation providers 22

3.3. Pilot study objectives and methodology 22

3.4. Indonesia: an ideal candidate for a pilot study on TOSSD 23

4. Indonesia's economic and financing landscape 24

4.1. Indonesia's economic and development situation $\quad 24$

4.2. Development finance landscape 26 
5. Main concepts and definitions of the TOSSD statistical framework 31

5.1. Definitions: the "TOSSD statistical measure", "sustainable development", "resource flows" (§8-10-11-12 of the reporting instructions)

5.2. Definition of officially supported (\$13-14 of the reporting instructions) 32

5.3. Definition of international public goods, global challenges and development enablers (§1518 of the reporting instructions)

5.4. A two-pillar approach: "cross border flows" and "global and regional expenditures" (§19-21 of the reporting instructions)

5.5. Statistical quality standards in the TOSSD system and users of the TOSSD data (§22-23 of the reporting instructions)

5.6. Activity-level reporting ( $\$ 24-25$ of the reporting instructions)

5.7. Point of measurement ( $\$ 26-27$ of the reporting instructions)

6. TOSSD pillar I: cross-border resource flows in support of sustainable development 37

6.1. Scope of cross-border resource flows pillar (\$39-42 of the reporting instructions) 37

6.2. Eligibility criteria regarding sustainable development ( $\$ 47-49$ of the Reporting Instructions) 40

6.3. TOSSD-eligible countries (§50-51 of the Reporting Instructions) 41

6.4. Measurement of technical co-operation (\$53-57 of the Reporting Instructions) 41

6.5. Measurement of resources mobilised from the private sector ( $\$ 58-59$ of the reporting instructions)

7. Regional and global expenditures in support of sustainable development and review of Annex E of the TOSSD Reporting Instructions

7.1. TOSSD Pillar II: regional and global expenditures in support of sustainable development

7.2. Review of Annex $E$ on additional guidance on the eligibility of specific themes

8. Reporting format and detailed instructions

8.1. Reporting cycle ( $\$ 73-74$ of the Reporting Instructions)

8.2. Reporting instructions item by item ( $\$ 77-89$ of the Reporting Instructions)

Part IV. Financing for sustainable development provided by Indonesia and capacity to report on TOSSD

9. Official support provided by Indonesia to other countries and capacity to report on Pillar I

9.1. Overview of Indonesia's development co-operation and institutional architecture for development finance data

9.2. A strong capacity to collect data on TOSSD Pillar I, but some scope for increased data coverage

10. Indonesia as a provider of finance for international public goods (TOSSD Pillar II) 69

10.1. Public finance for international public goods in Indonesia

10.2. Capacity of Indonesia to measure and report on public finance for international public goods 
11. Conclusion and next steps $\quad 81$

$\begin{array}{ll}\text { Annexes } & 82\end{array}$

Annex A. List of institutions visited during the in-country mission 83

$\begin{array}{ll}\text { References } & 84\end{array}$

Tables

Table 1.1. Estimated TOSSD resources provided by Indonesia

Table 4.1. Official development finance and officially supported export credits to Indonesia, disbursements, USD million

Table 4.2. Private flows to Indonesia, USD million 28

Table 10.1. Research \& Development grants provided by the Ministry of Research and Technology in 201977

\section{Boxes}

Box 1. The potential for collecting data beyond official resources: philanthropic flows, remittances and other types of private investments 


\section{Executive summary}

Total official support for sustainable development (TOSSD) is a new metric that measures official flows, and private flows mobilised by the official sector, to support sustainable development. This TOSSD country pilot study aimed to obtain the perspective of Indonesia on the concept and methodology of TOSSD, estimate TOSSD flows from Indonesia in support of sustainable development and carry out a light assessment of the capacity of the country to report on TOSSD. The pilot study includes specific recommendations to the international TOSSD Task Force and the Government of Indonesia. The study has three key findings: First, Indonesia finds the TOSSD concept relevant for measuring the financing of the SDGs but suggests adjusting some key features of the TOSSD methodology (Part III). Second, the TOSSD concept responds to Indonesia's information and communication needs on financing for sustainable development. Third, Indonesia is able to report on a wide range of TOSSD activities, both on cross-border resources (Pillar I) and regional and global expenditures for sustainable development (Pillar II). TOSSD by Indonesia was estimated at USD 6376 million in 2017, with USD 16 million for Pillar I and USD 6360 million for Pillar II. Indonesia does not currently use instruments to leverage private finance for sustainable development.

Indonesia finds the TOSSD concept relevant for measuring the financing of the SDGs (see Part III). Indonesia supports the two-pillar approach and most definitions used in the TOSSD methodology. Indonesian actors also support many of the options taken in the TOSSD methodology, for example to include Islamic Finance or to make TOSSD data available at the activity-level. On TOSSD Pillar II, Indonesia finds it relevant to include activities carried out both at the international (e.g. international surveillance on communicable diseases) and domestic (e.g. health R\&D) levels that support the provision of international public goods which are relevant for the Sustainable Development Goals (SDGs).

However, Indonesia also suggests adjusting some key features of the TOSSD framework (see 4.2.3.Part III). Indonesia would favour including the "governance" dimension in the TOSSD definition of sustainable development. Many stakeholders stressed that the data reported by providers in Pillar I should also be validated by recipient countries, as providers and recipients can have different views on whether some resources are in fact supporting the recipient country. A representative of the Ministry of National Development Planning/Bappenas did not agree with the general eligibility criteria for Pillar II, which state that activities need to provide "substantial benefits to TOSSD-eligible countries or their populations", and recommended that clarifications be made regarding this criteria. Indonesia advocates for including domestic financing for climate adaptation (currently only climate mitigation expenditures are covered) as support to international public goods and global challenges, and recommends excluding activities of international tribunals, as nationally-driven reconciliation processes should be given priority.

The TOSSD concept can fulfil Indonesia's information needs on financing for sustainable development. Indonesia found the TOSSD framework useful for its development planning. The national budget can only finance $25 \%$ of Indonesia's next development plan. With TOSSD, Indonesia could identify additional resources that can complement its national budget by analysing how financing packages are put together in other countries (financial terms of official external borrowing, mechanisms for mobilising 
private finance, etc.). Finally, according to the National SDGs Secretariat, TOSSD can provide valuable information to monitor financing targets included in the SDG global indicator framework.

TOSSD could support Indonesia's communication needs and make the government funding efforts for sustainable development more visible (see sections 9.1 and 10.1.4) both for the Indonesian and international public. TOSSD can support current efforts by the government to streamline its development co-operation towards other countries (TOSSD Pillar I). In addition, Indonesia allocates a significant part of its national budget towards activities that support SDG-relevant international public goods (TOSSD Pillar II), in particular on climate change, biodiversity and peace and security. Making these activities transparent through TOSSD could help the government demonstrate how its national budget spending is benefiting the international community and is aligned with Indonesia's international commitments.

Indonesia has a well-structured data collection process for South-South and triangular cooperation (SSTC) but there is scope for reporting more comprehensive data in TOSSD Pillar I (see Section 9.2.). Data collection and reporting is constrained by the fact that ministries are not legally obliged to report comprehensive data and Indonesia lacks a clear definition of "development co-operation" and what it encompasses.

Indonesia also has the capacity to report on a number of activities in TOSSD Pillar II (see section 10.2.), for example climate mitigation expenditures. Indonesia collects data on publicly-funded R\&D projects although these data do not cover activities of all government research institutions. Indonesia is currently not able to report on its contributions to peace operations given that the corresponding budgets are confidential.

\section{Key recommendations to the TOSSD Task Force for adjusting the TOSSD framework:}

- Include a fourth dimension on 'governance and justice' in the definition of TOSSD. This would be in line with the SDG framework since these issues are covered in SDGs 16 and 17.

- Introduce a validation mechanism of TOSSD data by recipient countries, for example through a regular bilateral consultation mechanism with recipient countries.

- Create a technical assistance mechanism for countries to request specific support on TOSSD data reporting or analytical aspects.

Key recommendations to the Government of Indonesia to enhance its capacity to collect and report data on financing for sustainable development:

- Provide the new Indonesian Agency for International Development, Indonesian-AID, with the mandate to collect, compile and disseminate data on development co-operation from all sources. This would make Indonesian-AID the "one-stop shop" of Indonesia for all data on development cooperation.

- Adopt a definition of development co-operation, possibly comprising the full spectrum of assistance provided by Indonesia to other developing countries. This would help clarify the role of the new Indonesian-AID and design a comprehensive development co-operation strategy.

- Set-up a dedicated data portal for Indonesian-AID and publish activity-level data. This would enhance the communication on Indonesian's contributions to sustainable development and provide one point of entry for all stakeholders.

- Participate in global efforts to report data on development co-operation based on international standards, for example by reporting on TOSSD starting from 2020. This will help Indonesia promote its sectoral expertise in development co-operation.

- Consider reporting on Indonesia's public finance for international public goods, including on climate mitigation, biodiversity, Research and Development (R\&D) and peace and security. Indonesia 
allocates a significant part of its national budget towards these activities and would benefit from showing how its national policies are aligned with international commitments.

- Strengthen the capacity of the Ministry of Research and Technology (MoRT) to collect, compile and disseminate data on R\&D projects supported by the Government, in particular through the implementation of the new regulations that request all government institutions receiving R\&D envelopes from the State budget to report on their activities to the MoRT. This would allow the Government to enhance the effectiveness of Indonesia's spending on R\&D and better communicate these efforts to the public. 


\section{Part I. Main findings and recommendations}

Part I (Chapters 1. and 2. ) presents the main findings and recommendations of this report. The findings cover the perspective of Indonesia on TOSSD and its methodology, the usefulness of the measure to respond to the country's information needs, estimates of TOSSD provided by Indonesia and the main conclusions of the capacity assessment of the government to collect, compile and disseminate TOSSD data. Part I also includes recommendations to the International TOSSD Task Force to adjust the TOSSD Reporting Instructions, as well as some recommendations for the Government of Indonesia to further improve its process for managing development finance data. 


\section{General findings related to TOSSD and the TOSSD methodology}

Total official support for sustainable development (TOSSD) is a new metric that measures official flows, and private flows mobilised by the official sector, to support sustainable development. It comprises two pillars: The first consists of resources flowing into recipient countries in direct support of their sustainable development. The second consists of global and regional expenditures in support of international public goods and development enablers that will help all countries achieve sustainable development (e.g. stable climate, peace and the fight against communicable diseases).

The TOSSD country pilots aim at assessing the TOSSD methodology from the perspective of a particular country. Two objectives ${ }^{1}$ were assigned to the TOSSD Secretariat team for the Indonesia pilot:

- Explore the perspective of Indonesia on the TOSSD Reporting Instructions (e.g. definitions, concepts and eligibility criteria) and, if relevant, make recommendations to the TOSSD Task Force for adjusting the Reporting Instructions (see Part III).

- Investigate the potential of Indonesia as a provider of TOSSD resources, both on TOSSD Pillar I (cross-border resource flows to TOSSD-eligible countries) and Pillar II (domestic public finance in support of international public goods), including by providing estimates of TOSSD flows, and carry out a light assessment of the capacity of Indonesia to report on these resources (see Part IV).

The main findings can be summarised as follows:

- Indonesia finds the TOSSD concept broadly relevant but suggests adjusting some key features of the TOSSD framework.

- The TOSSD concept could fulfil Indonesia's information needs on financing for sustainable development, both as a recipient and provider of finance.

- As a provider of financing for sustainable development, Indonesia is able to report on a wide range of TOSSD activities, both in Pillar I and Pillar II.

\subsection{The perspective of Indonesia on the TOSSD concept and methodology}

Indonesia finds the TOSSD concept relevant for measuring the financing of the SDGs (see 4.2.3.Part III):

- Indonesia supports the two-pillar approach and finds that most definitions used in the TOSSD methodology are consistent with those used in the country (e.g. resource flows).

- Indonesian actors support many of the options taken by the International TOSSD Task Force, such as the importance of including Islamic Finance, measuring non-monetary resources and making data available at activity-level.

\footnotetext{
${ }^{1}$ See Part II for more detailed information on the context and terms of reference of this TOSSD pilot study.
} 
- Indonesian stakeholders are particularly interested in some of the parameters of the TOSSD methodology, such as the measurement methodology of in-kind technical co-operation using a Purchasing Power Parity factor.

- On TOSSD Pillar II, Indonesia finds it relevant to include activities carried out both at the international (e.g. norm-setting) and domestic (e.g. climate mitigation) level that support the provision of Sustainable Development Goals (SDG)-relevant international public goods.

- Indonesia supports the eligibility criteria for specific items in Annex E of the Reporting Instructions.

However, Indonesia also suggests adjusting some key features of the TOSSD framework (see 4.2.3.Part III):

- Indonesia would favour including a "governance and justice" component in the TOSSD definition of sustainable development. From Indonesia's perspective, "governance and justice" is a key, fourth dimension of sustainable development, in addition to the economic, social and environmental components.

- Several stakeholders advocated for more operational rules on the eligibility of some activities (e.g. would coal-fired power plants that include technology to reduce GHG emissions be eligible?).

- On Pillar I ("officially supported resource flows to promote sustainable development in developing countries"): many stakeholders stressed that the data reported by providers should also be validated by recipient countries, as providers and recipients can have different views on whether some resources are in fact a support to the recipient country. For example, providers claimed some loans to Indonesia as climate support while Indonesia does not consider them as support.

- On Pillar II ("support to international public goods, development enablers and global challenges"):

- A representative of the Ministry of National Development Planning/Bappenas questioned the eligibility criteria for Pillar II and found them not sufficiently operational. The official recommended that clarifications be made regarding the criterion that activities need to provide "substantial benefits to TOSSD-eligible countries or their populations".

- Indonesia confirmed the relevance of including in Pillar II domestic financing for R\&D, to the extent that results of the R\&D benefit populations worldwide, and international co-operation for sustainable development. The need to track these investments in international public goods became more urgent with the Covid-19 pandemic crisis.

- Indonesia advocated for including domestic financing for climate adaptation (currently only climate mitigation is included) as supporting international public goods and addressing global challenges, and recommended excluding activities of international tribunals, as nationallydriven reconciliation processes should be given priority.

\subsection{Usefulness of the TOSSD concept for Indonesia}

The TOSSD concept can fulfil Indonesia's information and communication needs on financing for sustainable development, both as recipient and provider of finance.

As a recipient of external finance, TOSSD can support Indonesia in its national planning and SDG monitoring (see Chapter 6. ):

- TOSSD can support Indonesia in identifying additional resources that can complement national budget resources. Indonesia estimates that its national budget can only finance $25 \%$ of 
its next development plan 2020-24. Indonesian officials highlighted two main areas where TOSSD could particularly help in this regard:

- Cross-country comparisons: Indonesia puts great emphasis on innovative financing (blended finance, Islamic finance for sustainable development, etc.) and is interested to know what kind of schemes other countries use to support their own national development processes. TOSSD could help in providing information on these schemes.

- Tracking private finance: Indonesia is keen to explore private finance for sustainable development and how to use official finance to catalyse private sector participation. Many Indonesian stakeholders emphasised that the key information gap is on private finance for sustainable development. Indonesian stakeholders were not completely familiar with the concept of private finance mobilised. However, they would appreciate getting access to this information (e.g. the National SDGs Secretariat to inform domestic SDG targets) but also on broader private finance (e.g. philanthropy).

- According to the National SDGs Secretariat, TOSSD can provide valuable information to measure how countries progress in financing the SDGs. For example, TOSSD could inform Goal 9: "Indicator 9.a.1 Total official international support (official development assistance plus other official flows) to infrastructure" of the national SDG indicator framework.

Internationally, Indonesia is an important provider of public resources for sustainable development and wishes to communicate these contributions to a wider public (see sections 9.1 and 10.1.4):

- TOSSD provides an opportunity to make Indonesian development co-operation in its entirety more visible, both for the Indonesians and internationally. Although Indonesia provides its development co-operation mainly through South-South and Triangular Co-operation (SSTC), other types of support exist. Examples include grants provided by the Ministry of Finance for different purposes (e.g. emergency, health, agriculture) or by the national Zakat ${ }^{2}$ agency The National Board of Zakat Republic of Indonesia - BAZNAS ${ }^{3}$. TOSSD comes at a particularly relevant time as the Government has established the Indonesian Agency for International Development, Indonesian-AID, and aims to streamline its development co-operation.

- Indonesia allocates a significant part of its national budget towards activities that support SDG-relevant international public goods. Indonesia is an important voice on the international stage, in particular on climate change, biodiversity and peace and security. Indonesian officials consider that making these activities transparent through TOSSD could help the Government demonstrate how its national budget spending is benefiting the international community and is aligned with Indonesia's international commitments.

\subsection{Assessment of the capacity of Indonesia to report on TOSSD}

Indonesia has a well-structured data collection process for Pillar I but there is scope for reporting more comprehensive data (see section 9.2.). Data collection and reporting is limited since ministries are not legally obliged to report comprehensive data and Indonesia lacks a clear definition of "aid". However, while SSTC data are consolidated and managed centrally by the SST National Coordination Team (NCT), data on other types of flows need to be collected from different government agencies, which complicates

\footnotetext{
${ }^{2}$ Zakat is an Islamic finance term. It is a religious obligation for Muslims and is regarded as a form of worship. It consists of donating a certain proportion of one's wealth each year to charitable causes.

3 The support provided by BAZNAS includes, but is not limited to, South-South co-operation. An example of SSC activity carried out by BAZNAS is a knowledge sharing project with the Nigeria Zakat and Infaq Commission to share best practices on zakat management - See https://khazanah.republika.co.id/berita/puzj9u423/sozecom-nigeria-danbaznas-bahas-pengelolaan-lembaga-zakat (in Indonesian).
} 
the reporting process. The Indonesian Agency for International Development, Indonesian-AID, which has recently been launched, should greatly help to consolidate all development co-operation data. Indonesia also highlighted the necessity to build national capacity on how to set-up the data collection system and how to analyse TOSSD data. For the purposes of this report, the mission team gathered, in addition to SSTC, information on resource flows provided the Ministry of Finance and BAZNAS. These data were also included in the 2019 TOSSD data survey on 2017 flows.

Indonesia also has the capacity to report on a number of activities in TOSSD Pillar II (see Section 10.2). Indonesia can easily report climate mitigation expenditures at a relatively disaggregated level (budget outputs). Data on biodiversity are available only at aggregate level. The Ministry of Research, Technology and Higher Education collects data on publicly-funded R\&D projects, although this data collection does not cover all government research institutions. Indonesia is currently not able to report on its contributions to peace operations given that the corresponding budgets are confidential. For the purposes of this report, the mission team gathered data on climate mitigation at budget output level and data on R\&D at aggregate level. Only data on climate mitigation were included in the 2019 TOSSD data survey on 2017 flows.

\subsection{Estimated TOSSD flows for Indonesia as a provider of financing for sustainable development}

Estimated TOSSD for Indonesia as a provider of financing for sustainable development amounts to USD 6376 million in 2017, with USD 16 million for TOSSD Pillar I and USD 6360 million for TOSSD Pillar II. Indonesia does not currently use leveraging instruments to mobilise private resources (e.g. loans or guarantees). This is why the table below does not include any amounts for private finance mobilised by Indonesia. 
Table 1.1. Estimated TOSSD resources provided by Indonesia

2017 commitments, USD million (unless otherwise specified)

\begin{tabular}{|c|c|c|}
\hline $\begin{array}{l}\text { CATEGORY OF } \\
\text { FLOW }\end{array}$ & $\begin{array}{l}\text { ESTIMATES } \\
(2017)\end{array}$ & NOTES AND SOURCES \\
\hline A. TOSSD Pillar I & 16 & \\
\hline \multicolumn{3}{|c|}{ South-South co-operation (SSC) } \\
\hline $\begin{array}{l}\text { Grants (excluding } \\
\text { in-kind technical co- } \\
\text { operation) }\end{array}$ & 7 & $\begin{array}{l}\text { South-South Co-operation resources provided by Indonesia to other developing } \\
\text { countries, e.g. technical co-operation in various sectors (agriculture, ecotourism, } \\
\text { etc.), scholarships and grants by the Ministry of Finance (e.g. development of a } \\
\text { health centre in Afghanistan) } \\
\text { Source: Ministry of National Development Planning/Bappenas, Ministry of Finance }\end{array}$ \\
\hline $\begin{array}{l}\text { In-kind South-South } \\
\text { Technical Co- } \\
\text { operation }\end{array}$ & $\ldots$ & Currently not measured \\
\hline \multicolumn{3}{|c|}{ Other official bilateral flows } \\
\hline $\begin{array}{l}\text { Grants (excluding } \\
\text { SSTC) }\end{array}$ & 2 & $\begin{array}{l}\text { Grants provided by Indonesia outside the framework of SSTC }{ }^{4} \text {. Based on } 2018 \\
\text { flows. } \\
\text { Source: Ministry of Finance of Indonesia }\end{array}$ \\
\hline $\begin{array}{l}\text { Grants provided by } \\
\text { BAZNAS }\end{array}$ & 7.2 & $\begin{array}{l}\text { Grants provided by the National Zakat Agency (BAZNAS) }{ }^{5} \text {. Based on } 2019 \text { flows. } \\
\text { Source: BAZNAS }\end{array}$ \\
\hline B. TOSSD Pillar II & 6360 & \\
\hline \multicolumn{3}{|c|}{ South-South co-operation (SSC) } \\
\hline Grants & 0.2 & $\begin{array}{l}\text { South-South Co-operation resources provided by Indonesia in support of global } \\
\text { challenges and development enablers (e.g. coordination of international } \\
\text { development co-operation and strategic coordination of SSC interventions). Source: } \\
\text { Ministry of National Development Planning/Bappenas }\end{array}$ \\
\hline \multicolumn{3}{|l|}{ Climate mitigation } \\
\hline $\begin{array}{l}\text { Climate mitigation } \\
\text { expenditures }\end{array}$ & 6359.5 & $\begin{array}{l}\text { Government expenditures in climate mitigation activities. } \\
\text { Source: Fiscal Policy Agency, Ministry of Finance }\end{array}$ \\
\hline \multicolumn{3}{|c|}{ Research \& Development } \\
\hline $\begin{array}{l}\text { Research \& } \\
\text { Development } \\
\text { expenditures }\end{array}$ & $\ldots$ & $\begin{array}{l}\text { As an indication of total public R\&D funding in Indonesia, Government Budget } \\
\text { Appropriation or Outlays on Research \& Development (GBARD) amounted to USD } \\
1.99 \text { billion in 2017. USD } 725.6 \text { million was provided through the Ministry of } \\
\text { Research and Technology and } 69.1 \text { million was provided through the Ministry of } \\
\text { Health. } \\
\text { Source: Ministry of Research and Technology (MoRT) }\end{array}$ \\
\hline \multicolumn{3}{|l|}{ Peace and security } \\
\hline $\begin{array}{l}\text { Expenditures in } \\
\text { support of } \\
\text { international peace } \\
\text { and security }\end{array}$ & $\cdots$ & $\begin{array}{l}\text { Indonesia incurs a number of expenditures in support of international peacekeeping } \\
\text { that could be reflected in TOSSD Pillar II (e.g. the Peace Forces training Centre in } \\
\text { Indonesia, expenditures related to the contribution of troops to UN peacekeeping and } \\
\text { activities carried out in the context of Indonesia's current membership in the UN } \\
\text { Security Council). However, data on these expenditures are currently not available, } \\
\text { either because they are subject to confidentiality (Ministry of Defence and Indonesia } \\
\text { National Police- Polri) or because they are not easily extractable from the } \\
\text { government budget systems (Ministry of Foreign Affairs) }\end{array}$ \\
\hline $\begin{array}{l}\text { Total TOSSD } \\
(\mathrm{A}+\mathrm{B})\end{array}$ & 6376 & \\
\hline
\end{tabular}

Note: The sustainable development financing data included in this table was collected from different ministries and government institutions during the country mission in Jakarta. 


\section{Recommendations and next steps}

This section formulates the main recommendations of the mission team that arose from this TOSSD country pilot.

\subsection{Recommendations to the international TOSSD Task Force for adjusting the TOSSD framework}

Indonesia was a particularly relevant country for testing the TOSSD Reporting Instructions given its position as both a provider and recipient of finance for sustainable development and its strategic position on the international stage for addressing many global challenges (e.g. environmental protection). The Task Force could consider the following suggestions made by Indonesia:

- Introduce a mechanism for validating TOSSD data by recipient countries. As a minimum, a bilateral consultation mechanism could be established whereby recipients can request further clarifications on data reported by providers.

- Include a fourth dimension on "governance and justice" in the definition of TOSSD. This would be in line with the SDG framework since these issues are covered in SDGs 16 and 17.

- Develop clear and operational rules on the sustainability filter, in particular the eligibility of certain types of activities e.g. fossil fuels, palm oil industry, improving environmental standards of coal-fired power plants.

- Provide a bigger focus on private finance in TOSSD, for example by launching the discussions on the TOSSD satellite indicators, in particular on private philanthropy.

- Discuss issues related to potential double counting between pillar I and pillar II in TOSSD, for example between budget support extended by external providers to Indonesia (pillar I) and domestic expenditures from Indonesia's national budget (pillar II).

Overall, Indonesia has strong capacity to report on TOSSD, but may require support to set-up specific procedures for collecting TOSSD data. Indonesia also highlighted the necessity to build national capacity to analyse TOSSD data.

- Create a technical assistance mechanism through which any reporting country could request specific assistance on data reporting or analytical aspects, either from the TOSSD Secretariat or a member of the Task Force. Given that TOSSD will cover many sustainable development activities that have never been reported in international development finance statistics, the technical assistance mechanism will probably be useful beyond the case of Indonesia. Specific resources will need to be allocated to support this mechanism. 


\subsection{Recommendations to the government of Indonesia to enhance its capacity to collect and report data on financing for sustainable development}

Indonesia aims to strengthen its development co-operation and make it more visible. This led in particular to the creation of the Indonesian Agency for International Development, Indonesian-AID, in October 2019. Based on the capacity assessment, the TOSSD Task Force Secretariat formulated to the Government of Indonesia the following recommendations:

- Adopt a definition of development co-operation, possibly comprising the full spectrum of assistance provided by Indonesia to other developing countries. Currently, the policy of Indonesia as a provider of development co-operation is mainly focussed on SSTC. However, the country mission showed that other types of assistance are provided to developing countries outside the framework of SSTC (e.g. grants provided by the Ministry of Finance for different purposes, student costs and humanitarian aid). A definition of development co-operation will help clarify the role of the new Indonesian Agency for International Development, Indonesian-AID, and provide it with the means to design and implement a comprehensive development co-operation strategy, using all of the available instruments and modes of co-operation.

- Participate in global efforts to report data in international statistics on development cooperation based on international standards, for example by reporting on TOSSD starting from 2020. With the creation of Indonesian-AID, it would be important that Indonesia contributes to international efforts to provide recipient countries and the international community with detailed information on its activities around the world. The capacity assessment shows that Indonesia is able to carry out this reporting. This will help recipient countries to get better access to Indonesian expertise and support the Government of Indonesia in its development co-operation efforts more visible. Indonesia could start this process by carrying out a comprehensive study of government activities in support of developing countries.

- Provide the Indonesian Agency for International Development with the mandate to collect, compile and disseminate data on development co-operation from all sources, including SSTC but also other types of support provided by various government institutions (e.g. Ministry of Finance, Ministry of Foreign Affairs, Disaster Prevention Agency). In order to facilitate the task of the agency, Indonesia could develop a clear legal framework for collecting SSTC data, to ensure appropriate reporting by all line ministries and relevant institutions.

- Set-up a dedicated data portal for Indonesian-AID and publish activity-level data. This would enhance Indonesia's international profile, provide one point of entry for all stakeholders and give the opportunity to set up individual web pages for each project, which can then be linked in all communications to disseminate information.

Internationally, Indonesia is an important and strategic voice for providing many international public goods (e.g. climate stability, peace and security) that are key for achieving sustainable development. At the national level, Indonesia allocates a significant part of its national budget towards activities supporting these international public goods. By providing transparency on these activities, TOSSD can be a strong tool to support the Government's international policies and advocacy efforts.

The following recommendations are formulated by the TOSSD Task Force Secretariat to Indonesia, based on the capacity assessment carried out during the country mission:

- Consider reporting through TOSSD on Indonesia's public finance for international public goods, including on climate mitigation, biodiversity, R\&D and peace and security. Given that Indonesia allocates a significant part of its national budget towards these activities, reporting on them would show the international community how its national budget spending supports regional and global sustainable development. It will also allow the Government demonstrate how its national 
policies are aligned with its international commitments. Some of these expenditures are today easily reportable by Indonesia (e.g. climate mitigation).

- Strengthen the capacity of Ministry of Research and Technology (MoRT) to collect and disseminate data on R\&D projects supported by the Government. Low R\&D budget and poor coordination in research activities are two main challenges of R\&D management in Indonesia (Ministry of National Development Planning/Bappenas, 2019, p. $\left.88_{[1]}\right)$. In order to allow the Government to efficiently allocate scarce public resources to R\&D, transparency on R\&D projects that are ultimately supported by the Government is key. Since 2018, new regulations request all ministries and government research institutions that receive R\&D funds from the central budget to report project-level data on their R\&D activities to the MoRT. However, efforts could now focus on the implementation of these regulations as the in-country mission revealed that there can be issues relating to under-reporting by government entities beyond the MoRT.

- Explore the possibility to disclose and report on TOSSD expenditures related the Peace Forces Training Centre. The Centre provides pre-deployment trainings and capacity-building for UN peacekeepers. Given the repeated calls made by Indonesia to adequately prepare peacekeeping operations, including in the context of its current membership in the UN Security Council, these data could show how Indonesia is making efforts in this regard.

- Extend the budget tagging system, currently applied to climate expenditures, to also track activities supporting biodiversity. Indonesia hosts the third largest rainforest area in the world, and is home to one of the richest biodiversity in the globe. This biodiversity benefits not only the populations of Indonesia but also the whole globe, which is why it is prominently placed in the SDGs (SDG 14 on life below water and SDG 15 about life on land). The Government of Indonesia would greatly benefit from showing the Indonesian and international public, through TOSSD, how it is contributing to preserve it.

\subsection{Next steps}

Following the TOSSD pilot, the Government of Indonesia decided to become a member of the international TOSSD Task Force. Indonesia, through the Ministry of National Development Planning/Bappenas, will now participate in all Task Force meetings and will be a key stakeholder in the development of the TOSSD measure. Indonesia will bring a particularly relevant perspective in the TOSSD discussions in the areas of environmental sustainability, peace and security, the measurement of South-South Co-operation and the importance of Islamic finance for sustainable development. It will also voice the concerns and expectations of the Asia-Pacific region, along with other countries from the region that are members of the Task Force (e.g. the Philippines and Timor Leste).

The recommendations formulated to the TOSSD Task Force in this report will be discussed at an upcoming Task Force meeting. As regards the recommendations formulated by the mission team to Indonesia, the TOSSD Secretariat stands ready to support the Government of Indonesia in implementing the TOSSD framework at the country level, particularly for setting up a process for collecting, compiling, and reporting TOSSD data. 
Part II. Background information on TOSSD pilot studies and the context of Indonesia

Part II (Chapters 3. and 4. ) explains the TOSSD concept, the methodology and objectives of the TOSSD pilot studies. This part also briefly describes Indonesia's economic and development situation and gives an overview of its development financing landscape. 


\section{Context and objectives of the country pilot study}

\subsection{The concept of TOSSD}

Many developing countries have access to a growing array of officially supported financing, some of which result from the involvement of new actors in development finance. This includes non-concessional resources and private capital, usually in co-financing arrangements with public finance. As countries turn towards different types of official support, they become less reliant on official development assistance (ODA). With the increasing number of actors and instruments available, a transparent and inclusive measurement framework is needed to reflect the totality of international public finance flows provided to promote sustainable development.

The Addis Ababa Action Agenda (AAAA) called for a holistic approach that enhances synergies between actors, recalling the shared pursuit of sustainable development and national ownership. Moreover, it recognised the crucial role of international official development finance particularly, supporting capacity building to mobilise additional domestic resources and catalysing resources from international public and private sources.

Since the Addis Ababa Conference, the OECD has been working in consultation with the international community to develop a new measurement framework for the Sustainable Development Goals (SDGs) era called total official support for sustainable development (TOSSD). The TOSSD framework aims to provide a comprehensive picture of external official support for sustainable development and flows mobilised through official interventions, thereby facilitating a common international reporting standard for all providers of development co-operation, including emerging economies.

TOSSD will encompass all financing provided by official bilateral and multilateral institutions, regardless of the level of concessionality involved or instrument used. It includes both concessional and nonconcessional financing provided through various instruments, e.g. grants, loans, equity and mezzanine finance, among others. It also aims to cover activities that promote and enable sustainable development, including contributions to global public goods that are relevant for development. It aims to create appropriate incentives for using international public finance and risk mitigation instruments to mobilise additional resources for development.

The TOSSD measurement framework ${ }^{6}$ is composed of two pillars tracking officially supported (i) crossborder or external flows to developing countries and (ii) finance for promoting development enablers and addressing global challenges at regional and global levels.

\footnotetext{
${ }^{6}$ For further information on TOSSD, see: What is total official support for sustainable development (TOSSD)? (OECD, n.d. $[68])$.
} 
In the first semester of 2017, an International Task Force ${ }^{7}$ was established to carry out the technical work required to operationalise TOSSD and ensure it conforms to international statistical standards.

\subsection{The critical importance of engaging with partner countries and South-South co-operation providers}

In order to establish TOSSD as a viable, relevant and robust international statistical standard, the support and engagement of emerging providers and developing countries are fundamental. The OECD has already carried out five country pilots in Senegal, the Philippines, Nigeria, Costa Rica and Burkina Faso, which provided many insights, including on statistical boundaries (e.g. regarding the inclusion of costs incurred in provider countries), measurement approaches (e.g. measurement of in-kind technical co-operation), and features required to help inform country policy and planning (e.g. budgeting, national accounts, balance of payments, debt sustainability). An additional pilot study on the theme of Peace and Security determined the statistical boundaries of TOSSD in this area. ${ }^{8}$

\subsection{Pilot study objectives and methodology}

The main objective of the pilot study was to assess the TOSSD methodology in the particular context of Indonesia. More specifically, the pilot study aimed to:

- Explore the potential of TOSSD to respond to Indonesia's information needs and address their concerns with regard to the management of development finance flows ${ }^{9}$. This included identifying major data gaps on outflows from Indonesia to other countries (e.g. South-South Co-operation, Islamic Finance and short term finance).

- Test specific technical or statistical parameters and methodological features of the TOSSD measure to refine the statistical methodology of TOSSD (called the "TOSSD Reporting Instructions") (International TOSSD Task Force, 2019[2] $)$.

- Provide estimates of TOSSD flows to Indonesia. Given the specific situation of Indonesia as a provider and recipient of development co-operation, it also aimed to estimate TOSSD flows provided by Indonesia, following the TOSSD methodology.

- Examine in particular whether specific aspects of the development co-operation extended by the Republic of Indonesia to other countries could usefully inform the set up and content of the TOSSD framework.

- Carry out a light assessment and develop specific recommendations on the domestic capacity to access, collect, analyse and disseminate data on development co-operation provided by Indonesia.

The pilot study methodology consisted of three phases: (a) a desk review of existing documentation and statistics, (b) an in-country mission from 19 to 30 August 2019 and (c) the final report of the study.

\subsubsection{Desk review}

The OECD conducted a statistical analysis of available data regarding sustainable development financing to and by Indonesia, drawing on OECD data on concessional and non-concessional official resources;

\footnotetext{
${ }^{7}$ For further information see: International Task Force (OECD, n.d.[71]).

${ }^{8}$ All pilot studies can be found in the OECD iLibrary (OECD, n.d.[72]).

${ }^{9}$ Including the level of detail that would be useful for domestic policy-making and strategic decision-making.
} 
data from other international sources, e.g. World Bank, IMF, UNCTAD; sources of private banking and business data. An analysis of key documentation related to the sustainable development financing situation of the country was also carried out, including budget and economic planning documents, development cooperation trends and features, national development assistance strategies, the results of Paris Declaration and Busan monitoring exercises, assessments and analyses by international financial institutions, etc. Regarding the capacity assessment component of the analysis, the desk review looked at the extent to which Indonesia produces information on the support it provides to other countries for sustainable development. Finally, the desk review also included the preparation of a specific questionnaire, to guide the discussions during the in-country mission.

\subsubsection{In-country mission}

The in-country mission consisted of a series of interviews designed to gather the views of a wide range of relevant stakeholders (see Annex A) about the objectives and scope of TOSSD, its core features and statistical parameters. It required the designation by Indonesia of a government focal point in charge of organising the interviews and supporting the OECD experts in collecting relevant information to produce the mission report.

\subsubsection{Final report}

The present document is the final report, which outlines the main findings and conclusions of the pilot study. These rely on the desk review, the in-country mission and additional inputs received from the Government of Indonesia after the mission.

\subsection{Indonesia: an ideal candidate for a pilot study on TOSSD}

The Republic of Indonesia represents an ideal candidate for hosting a TOSSD pilot. Indonesia is one of the most prominent demographic and economic actors in Asia, it attracts substantial amounts of concessional and non-concessional finance. Additionally, an OECD survey on Amounts Mobilised from the Private Sector by Official Development Finance Interventions has shown that Indonesia is among the top five recipients of private finance mobilised through official development interventions in the Asian region $\left(O E C D, 2017_{[3]}\right)$. Carrying out a TOSSD pilot is also very much in line with the collaboration between the OECD and the Government of Indonesia on development finance, for example in the context of the Tri Hita Karana Roadmap for Blended Finance (OECD, 2018[4]). Moreover, the country has played a leadership role in many international fora in recent years ${ }^{10}$. In this regard, Indonesia can help ensure the appropriate dissemination of the pilot findings in various international settings (UN ECOSOC, General Assembly, UN Statistical Commission, etc.).

\footnotetext{
${ }^{10}$ For example, Indonesia has been elected as a non-permanent member of the Security Council for two years starting in January 2019 (Ministry of Foreign Affairs of the Republic of Indonesia, 2019[70]).
} 


\section{Indonesia's economic and financing landscape}

\subsection{Indonesia's economic and development situation}

Indonesia is the largest economy in South East Asia and the $16^{\text {th }}$ in the world with a gross domestic product (GDP) of about 1042 billion USD in 2018 (World Bank, 2019 $9_{[5]}$ ). It is an upper middle-income country (World Bank, 2019[6]), a member of the G20 and has a stable economy that maintains annual GDP growth rates close to $5 \%$ since 2013. In recent years, Indonesia has been able to adjust and maintain steady economic growth through robust domestic private consumption and investment (IMF, 2019, p. $\left.5_{[7]}\right)$. Government's efforts to advance structural reforms that foster sustainable development and inclusive growth have largely contributed to strengthening resilience to external shocks. However, additional resources are required to uplift the standard of living of the population, preserve the environment, and unlock Indonesia's economic potential (OECD, 2018, p. 30[8]).

The position of Indonesia's GDP per capita contrasts with the performance of the overall economy (OECD, 2018, p. 40[9]]. With a GDP per capita PPP of 13229.54 USD in 2019, Indonesia ranks 100 of 191 economies (IMF, 2019 $[10])$, indicating that challenges such as labour productivity remain. The population of Indonesia is estimated to have reached 270.62 million people as of 2018, making it the fourth most populous country in the world (UN DESA, 2019[11]). Notwithstanding a favourable age structure, Indonesia has to overcome multidimensional obstacles, "narrow its skills gap and employ its labour force more effectively" (Taniguchi, Francisco and Naval, 2018[12]) as necessary conditions to reap the benefits of the demographic dividend.

Indonesia reached its objectives for 49 out of 67 Millennium Development Goals indicators (Gol, 2017, p. iv $\left.\mathrm{v}_{[13]}\right)$ and is committed to the 2030 Agenda for Sustainable Development. The Voluntary National Review presented to the United Nations in 2019 asserts that "for the Republic of Indonesia, implementing national development agenda is implementing SDGs" (Gol, 2019, p. $7_{[14]}$ ). Progress made in most of the SDGs indicators reflects government efforts to put into practice a comprehensive strategy that aligns national priorities to the 2030 Agenda. The SDGs roadmap published in $2019^{11}$ shows the way forward by establishing the priorities of action and the means required to accomplish those, projecting different scenarios of intervention.

The Government of Indonesia established a national development planning system to foster inter alia coherence, efficiency and responsiveness among national objectives and their respective implementation mechanisms (Gol, 2004 $\left.{ }_{[15]}\right)$. The main planning documents in the system include the long-term, mediumterm and annual national development plans, which are formulated by "the Ministries/Agencies" and "Regional Governments in accordance with their authority" (Gol, 2004[15]). The Medium-term development plan for the period 2020-2024 incorporated the 2030 Agenda. It integrated 105 out of 118 selected SDG

11 It can be accessed here: (Ministry of National Development Planning/Bappenas, $2019_{[1]}$ ), Roadmap of SDGs Indonesia (accessed on 13 February 2020). 
targets (Ministry of National Development Planning/Bappenas, 2019 ${ }_{[1]}$ ), while the previous plan had already included 94 targets.

Indonesia has made significant progress in implementing the SDGs. It has lifted many people out of poverty, reduced employment and inequality. The population of Indonesia living with less than USD 1.90 a day stood at 5.7\% in 2017 compared to $22.4 \%$ in 2007 (World Bank, 2019 ${ }_{[16]}$ ). Moreover, unemployment decreased from 6.4\% in 2015 to $5.3 \%$ in 2018 (Gol, 2019, p. $7_{[14]}$ ). According to the Human Development Index (HDI), Indonesia advanced between 2017 and 2018 from the medium to the high human development category with a score of 0.707 , and boasted an annual average HDI growth rate of $0.74 \%$ between 2010 and 2018. The Gini Ratio has constantly decreased in the recent years, from 0.414 in September 2014 to 0.382 in March 2019, evidencing progress in reducing the levels of income inequality (Statistics Indonesia, 2019 $\left.{ }_{[17]}\right)$. Regarding other SDGs, Indonesia has also advanced in providing greater access to universal education. From 2015 to 2018, "the adjusted net attendance rate at pre-primary education increased from $79.4 \%$ to $83.3 \%$ " (Gol, 2019, p. 8[14] ). Furthermore, the country was able to mainstream low-carbon development in the national planning agenda and reduced its Greenhouse Gas emission intensity by $27 \%{ }^{12}$ (Gol, 2019, p. $137_{[14]}$ ) and its Disaster Risk Index by $23.97 \%$ (Gol, 2019 , p. ${ }_{[14]}$ ) On marine protection (SDG 14), Indonesia committed to creating 20 million hectares of Marine Protected Areas (MPAs), and had already reached 19.3 million hectares in 2018 (Gol, 2019, p. 220[14]). Concerning the access to justice and inclusive institutions (SDG 16), Indonesia advanced on the Democracy Index from 70.09 (2016) to 72.11 (2017) (Gol, 2019, p. 8[14]). However, Indonesia still faces critical SDG-related challenges, the most important of which are high geographical disparities, infrastructure gaps, and forest losses. Growth and economic development have not been evenly distributed across the country. The Inequality-adjusted Human Development Index (IHDI) ${ }^{13}$ indicates an overall "loss"14 of $17.4 \%$ in 2018 due to inequalities in income, life expectancy at birth and education. (UNDP, 2019 , p. $309_{[18]}$ Infrastructure gaps, leaving certain parts of the country isolated, further exacerbate geographical inequalities. Comprising about 17500 islands, Indonesia has difficulties providing public infrastructure to the entirety of its population (Geospatial Information Agency of Indonesia, 2017[19]). This generates, for example, unequal access to education and economic opportunities (Gol, 2019, p. 34[14]). The gap in poverty rates between Jakarta, the most prosperous province, and Papua, the poorest province, was close to 25 percentage points in 2018 (OECD, 2019, p. 35[20]). The Government has been actively promoting investments in public infrastructure through state-owned enterprises and made progress in developing infrastructure. However, in a context of budgetary constraints, projects encounter feasibility issues, especially in the most remote areas (OECD, 2018, p. 122[8]). In addition, infrastructure needs hinder competitiveness, increasing the costs of doing business. The Global Competitiveness Report 2019 lowered Indonesia's rank five positions in one year; in 2019, it ranked 50 of 141 economies while in 2018 the country had occupied the $45^{\text {th }}$ position. According to the report, infrastructure is one of the most critical areas for improvement (World Economic Forum, 2019, p. 298[21]). Furthermore, Indonesia still struggles with becoming more resilient against disasters since it is confronted with an increase in natural disasters (Gol, 2019 , p. $\left.130_{[14]}\right)$, including climate-induced disasters ${ }^{15}$. Forest losses are another major concern of

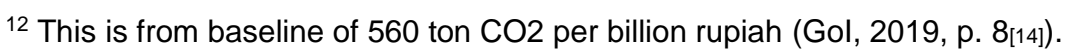

13 The IHDI combines a country's average achievements in health, education and income with how those achievements are distributed among country's population by "discounting" each dimension's average value according to its level of inequality.

14 The 'overall loss' presents the "percentage difference between the IHDI value and the HDI value" (UNDP, n.d.[69]).

15 Indonesia has already experienced extreme climate events such as floods and drought. According to Indonesia's 2016 Nationally Determined Contribution, "climate change is believed to increase the risk for hydro meteorological disasters, which make up to $80 \%$ of disaster occurrences in Indonesia."
} 
Indonesia. Deforestation rates remain among the highest in the world ${ }^{16}$ albeit actions taken by the Government to address the issue and the decrease of deforestation to 480 thousand hectares in 2017 (Gol, 2019, p. 143[14]]). In addition to their negative impact on biodiversity, forest losses are also one of the main drivers of GHG emission in Indonesia (Gol, 2019[14]).

\subsection{Development finance landscape}

Indonesia is striving to find different types of external financing, to provide supplementary resources to the national budget and overcome budgetary constraints. Finding additional resources is particularly critical for the country as domestic resources mobilisation is low compared to more advanced economies ${ }^{17}$ and since the Government only has the capacity to finance about $25 \%$ of the national development plan, according to the interviews carried out during the in-country mission. Indonesia already receives various types of official and private development finance that contribute to its development. Accordingly, the country has used innovative instruments, such as Green Sukuk, blended finance, Islamic charity, and social impact investments (Gol, 2019, p. 8[14]). Moreover, Indonesia is establishing a SDG Financing Hub "to reduce financing gaps and implement innovative financing sources through multi-stakeholder collaboration" (Gol, 2019, p. 8[14]).

\subsubsection{Indonesia as a recipient of official development finance}

The amount of official development assistance to Indonesia increased constantly from 2015 to 2018 . In 2018, members of the Development Assistance Committee (DAC), non-DAC countries as well as multilateral organisations disbursed around USD 3 billion of concessional finance to Indonesia. The main provider countries were Germany (46.6\%), Japan (21.3\%) and France (11.1\%).

Other Official Flows (OOF) disbursed to Indonesia decreased significantly between 2015 and 2018, from nearly USD 3 billion to USD 385 million. Most of OOF were provided by the Asian Development Bank (42.6\%), International Bank for Reconstruction and Development (34.8\%) and Asian Infrastructure Investment Bank (10.2\%) in 2018. In contrast to the decrease of OOF, officially supported export credits increased sevenfold from 2015 to 2018 and totalled approximately USD 3 billion in 2018.

\footnotetext{
16 The main causes of forest losses are the increase in palm oil and timber plantations in certain areas, the expansion of agricultural land in forest areas and Illegal, Unreported and Unregulated (IUU) activities (OECD, 2019, p. 41 [56])

17 According to the Revenue Statistics in Asian and Pacific Economies 2019, "Indonesia's tax-to-GDP ratio was $11.5 \%$ in 2017 , below the OECD average $(34.2 \%)$ by 22.7 percentage points, and also below the LAC and Africa (21)* averages $(22.8 \%$ and $18.2 \%$, respectively)" (OECD, 2019[63]).
} 
Table 4.1. Official development finance and officially supported export credits to Indonesia, disbursements, USD million

\begin{tabular}{l|c|c|c|c}
\hline \multicolumn{1}{c|}{ Type of Flow } & $\mathbf{2 0 1 5}$ & $\mathbf{2 0 1 6}$ & $\mathbf{2 0 1 7}$ & $\mathbf{2 0 1 8}$ \\
\hline Official development assistance & 1937 & 1947 & 2042 & 2955 \\
\hline Other official flows & 2948 & 2984 & 280 & 385 \\
\hline Officially supported export credits & 472 & 3652 & 4047 & 3158 \\
\hline
\end{tabular}

Note: Gross disbursements, 2017 constant prices, from all DAC, non-DAC providers and multilateral institutions Source: (OECD, n.d.[22]), Creditor Reporting System (CRS) and [DAC2b], https.//stats.oecd.org.

Other countries that do not report their data to the OECD, also contribute resources to Indonesia. According to AidData, in 2014, the People's Republic of China, for instance, channelled a total of approximately USD 1.5 billion ${ }^{18}$ of ODA-like, OOF-like and other official finance ${ }^{19}$ to Indonesia (AidData, 2017[23]).

\subsubsection{Private flows to Indonesia ${ }^{20}$}

In addition to official flows, Indonesia also benefits from private flows ${ }^{21}$. An OECD survey on Amounts Mobilised from the Private Sector by Official Development Finance Interventions ${ }^{22}$ has shown that Indonesia is among the top five recipients of private finance mobilised through official development interventions in the Asian region (Benn, Sangaré and Hos, 2017, p. 20[24]; OECD, 2017[3]). Indonesia received USD 1.4 billion of such flows from 2012 to 2015 (Benn, Sangaré and Hos, 2017[25]).

Moreover, philanthropic foundations' contributions to Indonesia increased greatly in the past years. Whereas Indonesia only received USD 9 million in 2016, it received USD 57 million from philanthropic donors in 2018. In this year, the main philanthropic donor was the Bill \& Melinda Gates Foundation (29.7\%) that allocated three-quarters of its total support to Indonesia to the "Population Policies / Programmes \& Reproductive Health" sector. The second biggest philanthropic donor was the Ford Foundation (26.3\%), with over half of its total allocated to the "Government \& Civil Society" sector. The third largest philanthropic contributor, David \& Lucile Packard Foundation (26.0\%), channelled over half of its total support to the "General Environment Protection" sector.

Other non-official flows included foreign direct investment to Indonesia that increased from USD 10 billion in 2015 to USD 19 billion in 2017 (net disbursements). After having decreased greatly in 2018, it totalled USD 20 billion in 2019 - the highest amount in the past five years. Personal transfers-receipts also reached a peak in 2019, totalling USD 11 billion (World Bank, n.d.[26]).

\footnotetext{
18 In 2014 constant prices.

19 This category of other official finance corresponds to what AidData defines as "Vague Official Finance" which is described as "[c]learly Official Finance, but [with] insufficient information to assign to either ODA or OOF" (AidData, n.d.[64]).

20 Private flows are excluded from TOSSD, with the exception of private finance mobilised. The figures in this section are only presented to show the entire landscape of external finance to Indonesia.

${ }^{21}$ See Box 1 for highlights on the potential for Indonesia to collect private finance for development.

22 This includes guarantees, syndicated loans, shares in collective investment vehicles, direct investment in companies and credit lines.
} 
Table 4.2. Private flows to Indonesia, USD million

\begin{tabular}{l|c|c|c|c|c}
\hline \multicolumn{1}{c|}{ Type of flow } & $\mathbf{2 0 1 5}$ & $\mathbf{2 0 1 6}$ & $\mathbf{2 0 1 7}$ & $\mathbf{2 0 1 8}$ & $\mathbf{2 0 1 9}$ \\
\hline Private philanthropy & 11.6 & 9.2 & 51.9 & 56.8 &.. \\
\hline Foreign direct investment (net) & 10704 & 16136 & 18502 & 12511 & 20145 \\
\hline Portfolio investment (net) & 16183 & 18996 & 21059 & 9312 & 21685 \\
\hline Personal transfers (receipts) & 9447 & 8687 & 8761 & 10974 & 11435 \\
\hline
\end{tabular}

Note: Amounts of Private Philanthropic flows are presented in gross disbursements and current prices.

Sources: (OECD, n.d.[27]), Private Philanthropy for Development (CRS), https.//stats.oecd.org.

(Bank Indonesia, n.d.[28]), Financial Account: Direct Investment (Table V.6.) and Financial Account: Portfolio Investment (Table V.7.), https://www.bi.go.id/en/statistik/seki/terkini/eksternal/Contents/Default.aspx.

(World Bank, n.d.[26]), Personal transfers, receipts (BoP, current USD) - Indonesia, https://data.worldbank.org/indicator/BX.TRF.PWKR.CD?locations=ID\&most_recent_value_desc=false\&view=chart.

\subsubsection{Legal framework and management of aid data as a recipient of development finance}

Indonesia has put in place a number of legal instruments to regulate its policies as a recipient of official development finance. The Government regulation 10 (2011) on "Procedures of Foreign Loans Procurement and Grants Receipt" regulates the approval, planning, administration and monitoring of this finance and provides the division of roles between the Ministry of Finance (MOF) and the Ministry of National Development Planning (Bappenas) in managing foreign loans and grants. For instance, to ensure debt sustainability, all loans and financial grants have to be approved by the MOF. Only in-kind grants can be directly accepted by a line ministry. (Gol, 2011 [29]) The MOF keeps data on all foreign flows (cash, projects, etc.).

The Ministry of National Development Planning/Bappenas, which is responsible for development planning, publishes in the "blue book" a list of projects that are eligible to be financed by loans and grants (Ministry of National Development Planning/Bappenas, 2018[30]). Projects for which the financing is ready are then listed in the green book (Ministry of National Development Planning/Bappenas, 2018[31]). The Ministry of National Development Planning/Bappenas has an internal system to monitor the development outcome of ongoing projects (e.g. performance, progress of disbursements). The MOF and the Central bank also have their own systems that are more focused on financial information (records transactions agreed and actual disbursements). Stakeholders interviewed during the country mission emphasised that, in order to improve its development planning capacity, Indonesia needs an integrated data system covering financial, monitoring and impact information on projects financed by external support, including for example the different instruments used in development financing. So far, a significant part of this information is tracked manually. For instance, the list of ongoing projects monitored by the Ministry of National Development Planning/Bappenas is tracked through an excel file which hampers the ability to monitor progress.

In terms of information gaps on development financing, interviews carried out during the in-country mission showed that Indonesia does not yet identify contributions from South-South Co-operation providers to Indonesia. Moreover, it lacks information and integrated data on resources from the private sector, philanthropy and official external support to the Indonesia's private sector. The management of funds from foreign providers (countries/multilateral institutions) to support SSTC activities is regulated by Government Regulation No. 10/2011 regarding Procedures for Foreign Loans Procurement and Grants. At the moment, the country is preparing a strategy and guidance on the aid it receives. Indonesia is also establishing a platform, called the SDG financing Hub that will collect data on all financing resources, including innovative financing. In the context of this Hub, the role of the Ministry of National Development Planning/Bappenas will be to facilitate match-making between development projects it has identified and prospective financing partners. At the time of writing, the institutional framework and standard operating procedures of the SDGs Financing Hub are still in preparation. In October 2019, at the SDGs Annual Conference, the Ministry of 
National Development Planning/Bappenas signed a MOU with the Asian Venture Philanthropy Network to support the SDG Financing Hub.

\section{Box 1. The potential for collecting data beyond official resources: philanthropic flows, remittances and other types of private investments}

The TOSSD measure covers only officially supported resources. However, in order to provide a wider view of development finance resources and for comparability purposes, TOSSD could be accompanied by satellite indicators on philanthropic flows and multiple types of private investment. It should be noted the TOSSD Task Force has not discussed this topic in detail yet.

Philanthropic flows: Indonesia formally recognised the role of non-state actors including philanthropic organisation to achieve the SDGs through the Presidential Decree no 59/2017 issued in July 2017. Several Indonesian stakeholders insisted on the critical importance for Indonesia to have more data on the contributions of private foundations to sustainable development. Indonesia supported several initiatives to strengthen philanthropic efforts to achieve the SDGs ${ }^{23}$ and is involving philanthropy in the preparation and implementation of the national development plans. ${ }^{24}$ Indonesian stakeholders emphasised the example of "Filantropi Indonesia", which is a non-profit organisation that has 122 members (organisations and individuals) from Indonesia. It was founded in 2003 to promote philanthropy in order to achieve social justice and sustainable development. "Filantropi Indonesia" focuses on three pillars: research and education; advocacy and facilitation; and communication and partnership. According to this institution, five types of private foundations are active in Indonesia: corporate foundations (UNILEVER, DANONE, etc.), family foundations, faith-based foundations, media-based foundations (e.g. ACTV channel), and foundations created by individual philanthropists. Many Indonesian foundations provide critical contributions to development (e.g. faith-based organisations, such as the "Muhammadiyah" and the "Nahdlatul Ulama"). The Tanoto foundation and Tahrir foundation are also two very active Indonesian foundations and operate both in Indonesia and overseas. More data on philanthropic resources may be available in the future as the "Lien Center for Social Innovation" of the Singapore Management University has been commissioned by the Ford Foundation to carry out a study of philanthropy in Indonesia ${ }^{25}$.

Remittances, FDI and portfolio investments: The Bank of Indonesia publishes data on remittances in their Indonesian Financial Statistics. The Survey of Indonesian Migrant Workers carried out by the Bank shows that they are essentially used for consumption. Bank Indonesia also publishes figures on FDI, Portfolio Investments and Other Investments in their Financial Accounts. ${ }^{26}$ These financial accounts track the external financing resources to the Indonesian economy. The 2030 Agenda calls for increasing private sector engagement in, and alignment with, the SDGs. For this purpose, Indonesia has signed a Memorandum of Understanding with the Global Reporting Initiative (GRI). ${ }^{27}$

23 The "SDG Philanthropy platform" is a UNDP project to connect philanthropic organisations across countries.

${ }^{24}$ For further information on the SDG Philanthropy Platform, see "What We Do" section in (SDG Philanthropy Platform, n.d.[67]).

25 https://lcsi.smu.edu.sg/research/philanthropy-china-india-indonesia

26 The tables with the figures can be accessed here: Indonesian Financial Statistics (Bank Indonesia, n.d.[65]).

27 For further information on the Memorandum of Understanding, see:

https://www.globalreporting.org/information/news-and-press-center/Pages/GRI-agrees-Memorandum-of-

Understanding-with-BAPPENAS.aspx and for more information about GRI, see About GRI (Global Reporting Initiative, n.d.[66]). 


\section{Part III. Indonesia's}

perspective on the TOSSD

Reporting Instructions

Part III (Chapters 5. , 6. , 7. and 8. ) presents the perspective of Indonesia on the TOSSD Reporting Instructions (RIs) (International TOSSD Task Force, $\left.2019_{[2]}\right)$. It is based on interviews carried out with a number of Indonesian stakeholders, mainly government officials, but Civil Society Organisations (CSOs) and private sector representatives were also consulted. The sections of the Rls that were discussed during the country mission are included in blue boxes and are followed by an analysis of their relevance from the perspective of Indonesia. Not all the sections of the RIs were discussed but only those that are particularly relevant to Indonesia. 


\title{
5. Main concepts and definitions of the TOSSD statistical framework
}

\author{
5.1. Definitions: the "TOSSD statistical measure", "sustainable development", \\ "resource flows" (§8-10-11-12 of the reporting instructions)
}

8. The total official support for sustainable development (TOSSD) statistical measure includes all officially supported resource flows to promote sustainable development in developing countries and to support development enablers and/or address global challenges at regional or global levels.

10. The concept of "sustainable development" is defined as development that meets the needs of the present without compromising the ability of future generations to meet their own needs.

11. "Sustainable development" in the TOSSD context is inherently linked to the Sustainable Development Goals as agreed in the 2030 Agenda. Activities recorded as TOSSD support the implementation of the SDGs by generating sustainable economic growth, ensuring social inclusion, without compromising the environment. As and when the 2030 Agenda is concluded and replaced by another framework, the TOSSD measure will be updated to link to that framework.

12. In accordance with the Addis Ababa Action Agenda, the term "resources" in the TOSSD definition covers both financial and technical resources. The flow of resources covers monetary and non-monetary transactions with TOSSD recipients in support of sustainable development for any given year.

The stakeholders met, in particular the SDGs National Secretariat, have generally supported the definition of TOSSD, although the concept of "officially supported" was not always perceived as straightforward, partly because it is not used in Indonesia (see below the section on the term "officially supported").

Indonesia has adopted an official definition of sustainable development in the context of the National Action Plan (NAP) $2017-19$ to achieve the SDGs ${ }^{28}$. The definition features the three core dimensions of sustainable development defined in TOSSD - the economic, social and environmental dimensions - but adds a fourth dimension, "governance and justice". The "governance and justice" dimension, which is a reflection of SDGs 16 and 17, is perceived as a fundamental pillar of sustainable development and an absolute prerequisite for progress in the other dimensions.

A number of stakeholders emphasised that the definition of sustainability should be more operational, with clear rules on the eligibility of some activities. For example, would the use of biomass residue from palm oil industries in energy production be eligible to TOSSD, given the impact of palm oil industries on deforestation? Would coal-fired power plants with carbon capture and storage be eligible? In the context

28 Presidential decree 59/2017, see Article 2, sub-section 2, concerning the implementation of SDGs (http://sdgs.bappenas.go.id/dokumen/). 
of SDGs reporting, Indonesia believes that many of its National Medium Term Development Plan (RPJMN) programmes and activities are aligned with the SDGs.

The stakeholders met during the pilot confirmed that the definition of resource flows used in TOSSD is appropriate and corresponds to the one used at the national level, in particular by Bank of Indonesia. In addition, the Bank of Indonesia confirmed that the definition is also consistent with the Balance of Payments Manual version $6^{29}$, which includes technical resources as cross-border flows. The National SDGs Secretariat emphasised the importance of technical assistance for Indonesia and for the achievement of the SDGs, but also stressed that the monetisation of technical assistance would provide only a partial picture of its importance for, and impact on, recipient countries (see also section 6.4 for more information on the perspective of Indonesia on non-monetary resource flows and particularly on in-kind technical co-operation).

\subsection{Definition of officially supported (\$13-14 of the reporting instructions)}

13. TOSSD aims to capture the entirety of instruments and modalities used by official provider countries and organisations to support sustainable development, including mechanisms that mobilise resources from the private sector. Therefore, in the context of TOSSD, "officially supported resources" are defined as:

a) resources provided by:

i) official agencies, including state and local governments, or by their executive agencies, and

ii) public sector corporations.

b) private resources mobilised by official interventions, where a direct causal link between the official intervention and the private resources can be demonstrated.

Indonesia's perspective on the TOSSD concept was particularly instructive. First, on the definition of "officially supported", Indonesia advocated for the introduction of a new dimension which would reflect the views of recipient countries. From Indonesia's point of view, it is important that both the provider and recipient agree on what is considered as "support", and as such the activities reported by a provider should also be validated by the recipient. Indonesia emphasised that a number of activities reported by providers as support to Indonesia, are not considered as an external support by the country (e.g. climate finance, support through NGOs). For example, Indonesia does not use foreign loans to finance environmental activities, and in terms of external assistance in this field, prefers the use of grants. In addition, Indonesia considers that "climate support" should cover all activities that address climate change as defined in the recipient country priorities.

In terms of official agencies covered, Indonesia highlighted that its national Zakat ${ }^{30}$ agency, BAZNAS (the national Board of Zakat of the Republic of Indonesia ${ }^{31}$ ) is covered by the definition of official agencies contained in the TOSSD framework ${ }^{32}$. Its resources originate from both private alms paid by institutions, individuals, government-owned companies and civil servants. BAZNAS is an independent government institution that has the mandate to i) collect and distribute Zakat (obligatory Islamic alms), Infaq (donations), and Sadaqah (alms) at the national level and ii) supervise the collection, distribution and utilisation of Zakat

\footnotetext{
${ }^{29}$ See https://www.imf.org/external/pubs/tt/bop/2007/pdf/bpm6.pdf

30 Zakat is an Islamic finance term referring to the obligation that an individual has to donate a certain proportion of wealth each year to charitable causes. Zakat is a mandatory process for Muslims and is regarded as a form of worship.

${ }^{31}$ BAZNAS was established by Presidential Decree of the Republic of Indonesia No. 8, dated 17 January 2011.

32 Para 13 of the TOSSD Reporting Instructions (International TOSSD Task Force, 2019[2]).
} 
by the private institutions authorised by the Government (these institutions are called LAZNAS). When activities contribute to the SDGs, they are tagged against the relevant SDG targets. More than $40 \%$ of the Zakat funds disbursed by BAZNAS are explicitly targeting the SDGs. In addition, the private Zakat institutions report to BAZNAS their activities, a significant part of which are also linked to the SDGs.

Indonesia considers BAZNAS as covered by the definition of "officially supported" for the following reasons:

- BAZNAS is a public institution that has an official mandate to manage Zakat funds.

- Zakat is explicitly mentioned in the Zakat management Act 23 (2011).

- BAZNAS is responsible for the allocation of zakat funds it collects.

- Indonesia does not consider Zakat as fully private resources because, although Zakat is not a mandatory tax in the Indonesian law, it is considered as a religious obligation. The Government is currently discussing an amendment of the Zakat Management Act that would make Zakat an obligation under the Indonesian law. In this new amendment, Zakat would be considered as a tax credit (amount of money that taxpayers can subtract from taxes owed to their government) whereas it is now considered as a tax deduction (reduction of the amount of taxable income).

Regarding the support provided by public sector corporations, one interviewee inquired about foreign public corporations that have subsidiaries operating in Indonesia. Some of these subsidiaries finance sustainable development projects in Indonesia. Would these expenditures be considered as external support to Indonesia or as domestic resources?

A number of interviewees were not familiar with the concept of "private resources mobilised by official interventions" and suggested to add a footnote specifying what the term "private resources" actually covers in the context of TOSSD. However, Indonesia supported the inclusion of this type of finance in TOSSD and recommended a broader coverage of private finance for the SDGs, which is a top priority for the Government. Several interviewees have emphasised that the key information gap for the authorities today in terms of SDG financing is related to private finance, emanating both from businesses and philanthropic organisations, both from external and domestic sources.

\subsection{Definition of international public goods, global challenges and development enablers (\$15-18 of the reporting instructions)}

8. International Public Goods (IPGs) are goods which provide benefits that are non-exclusive and available for all to consume at least in two countries. ${ }^{33}$ The term "good" refers to resources, products, services, institutions, policies and conditions.

9. Global challenges are issues or concerns that bring disutility on a global scale and that need to be addressed globally.

10. There is a significant overlap between IPGs and global challenges. Global challenges are often the opposite of IPGs (e.g. climate change and stable climate). However, not all activities addressing global challenges are IPGs (e.g. primary education programmes).

11. Development enablers are the means that help provide IPGs and/or address global challenges. They often have the characteristics of IPGs. They can be seen as "intermediate" IPGs as opposed to final IPGs.

As part of the study, the authors have tried to identify whether Indonesia was supportive of these three concepts and of their definitions in the Reporting Instructions. Indonesia indicated that further inclusive

${ }^{33}$ Not all countries have adopted the concept of international public goods. 
discussions need to take place on the definition of IPGs and how to measure contributions to those. As a member of the TOSSD Task Force, Indonesia will be able to contribute to the discussions on further finetuning of the IPG concept.

\subsection{A two-pillar approach: "cross border flows" and "global and regional expenditures" (\$19-21 of the reporting instructions)}

19. TOSSD is a two-pillar framework that tracks officially supported i) cross-border resource flows to developing countries and ii) global and regional expenditures, in support of development enablers, international public goods and to address global challenges.

20. International public goods include global public goods, whose benefits are nearly universal (e.g. stable climate), regional public goods (e.g. transboundary water management), whose benefits extend to countries that belong to the same region, and other IPGs whose benefits are neither global nor regional (e.g. bilateral trade agreements). The "regional" dimension can also apply to "challenges" (e.g. acid rains can be considered as a regional challenge) and "development enablers" (e.g. regional peacekeeping activities).

Indonesian stakeholders supported the two-pillar approach, recognizing the importance of responding to the SDGs at all levels, including at the domestic and international levels. Indonesia emphasised the relevance of international co-operation to achieve the SDGs, for example in the fight against terrorism. See section 7.1.2 for the perspective of Indonesia regarding the delineation between Pillar and Pillar II.

21. Data generated through the TOSSD framework can also be used to compile aggregates on sustainable development finance from the providers' perspective.

This paragraph of the Reporting Instructions was initially drafted to open the door for provider countries to use TOSSD to reflect the entirety of their contributions to the SDGs, which is comprised of their bilateral contributions, but also contributions made to/through multilateral institutions. When provider countries contribute to multilateral institutions, it is not possible for them to have a comprehensive picture of the final use of their contributions (e.g. amount effectively reaching recipient countries), in particular when these contributions support the core budget of the institution. One way to estimate provider countries' contributions to the SDGs made through multilateral institutions is to attribute a share of multilateral institutions' outflows to the SDGs back to provider countries, using for example the share of each provider country in the multilateral institution.

Indonesian officials expressed reservations concerning the attribution of multilateral outflows back to provider countries, in particular if this is based on their share in the multilateral institution. First, this would inflate the actual contribution made by individual countries towards sustainable development (for a given provider, a share of the outflows would be added to its direct bilateral support to recipient countries, thereby increasing the overall perceived volume of support). Second, the strategies and operations of multilateral institutions do not necessarily reflect the policies of their individual country members or shareholders, and as such, should not be attributed back to them. Regarding multilateral financial institutions and development banks which provide loans, Indonesia considers that it is the recipient country who makes the contribution to sustainable development as these loans are eventually repaid to the multilateral institution. In general, Indonesia prefers that multilateral outflows are not attributed back to provider countries. However, an exception could be made for multilateral institutions which are fully dedicated to the SDGs (e.g. climate change, women empowerment) and only provide grants or technical assistance to recipient countries. 


\subsection{Statistical quality standards in the TOSSD system and users of the TOSSD data (\$22-23 of the reporting instructions)}

23. Data collected on TOSSD under these Reporting Instructions should comply with the United Nations Fundamental Principles of Official Statistics (FPOS) which were adopted by the United Nations Statistical Commission (UNSC) in 1994 and by the United Nations General Assembly in 2014.

24. Moreover, the TOSSD statistical framework is subject to the United Nations Statistics Quality Assurance Framework. The TOSSD system is operated to ensure the quality of the statistical outputs (relevance, coherence, accuracy, reliability, timeliness and punctuality, interpretability and accessibility) and statistical processes (sound methods, cost efficiency and non-excessive burden on reporters). The governance of the TOSSD measure will ensure the quality of the institutional environment (objectivity, impartiality, transparency and credibility), essential to build trust which is the very foundation of a statistical system.

TOSSD presents the United Nations Fundamental Principles of Official Statistics (FPOS) as the reference to ensure the quality of the data collected. Statistics Indonesia (Badan Pusat Statistik) confirmed that the UNFPOS serve as the reference in Indonesia and are the appropriate statistical standards if TOSSD aims at being an international and inclusive statistical measure. Indonesian stakeholders also recognised that there might be challenges related to the implementation of the standards.

\subsection{Activity-level reporting (\$24-25 of the reporting instructions)}

24. All TOSSD resource flows are reportable at the activity level. The term "activity" covers various types of operations, ranging from budget support to project-type interventions, investments and technical co-operation activities. In certain cases some aggregation is permitted to limit the reporting burden and number of records. (See section 4.2.)

25. All TOSSD data will be made publicly available, also at activity level. Any information linked to TOSSD activities subject to confidentiality regimes (e.g. company names) should be filtered out upstream by the data providers.

Many Indonesian stakeholders, including government officials and CSO representatives, stressed the need to have activity-level reporting in TOSSD. The national development planning carried out by the Ministry of National Development Planning/Bappenas is based on activity-level data. Moreover, it was emphasised that evidence-based policies need to be investigated at activity-level.

The interviews with CSOs in Indonesia highlighted the importance of project-level information in order to allow scrutiny and assess impact. They provided specific examples from a study that shows that the impact of some projects supported by external providers is mixed ${ }^{34}$. They suggested to look at these efforts to integrate in the TOSSD framework information on impact.

Indonesian stakeholders also supported the tracking, at project-level, of private sector activities carried out with funding from bilateral and multilateral Development Finance Institutions (DFIs). Information that should be made available should include at least the project name, the amounts, the sector and the name of the companies involved. These data are necessary to inform policy discussions and are currently missing.

\footnotetext{
34 They cited for example a study, carried out by the International Initiative for Impact Evaluation (3IE), and that assesses the impact of Community-Driven Development (CDD) programmes based on 25 impact evaluations, covering 23 CDD programmes in 21 countries, including in Indonesia. (White, 2018[73]) See in particular Figure 8 p. 27 for an overview of the effects of these programmes.
} 


\subsection{Point of measurement (\$26-27 of the reporting instructions)}

26. TOSSD resource flow data are reportable on a calendar year basis. Both commitment and disbursement data are collected. A commitment is a firm written obligation by the provider, backed by the appropriation or availability of the necessary funds, to provide specified resources under specified financial terms and conditions and for specified purposes for the benefit of the recipient. Commitments are considered to be made at the date the financial agreement is signed or the obligation is otherwise made known to the recipient. A disbursement is the placement of resources at the disposal of the recipient.

27. The main TOSSD measure is calculated on a gross disbursement basis. Gross figures reveal the full scope and nature of external resources provided for sustainable development. The net measure is also calculated for transparency and analytical purposes, based on information reported on reflows (amounts received by the provider).

The Ministry of Finance confirmed that both the concepts of commitments and disbursements are used in Indonesia, and their definitions are similar to the ones used in TOSSD. Indonesia supported the publication of the main TOSSD measure based on a gross disbursement basis in order to cover the total volume of resources extended. Information on net disbursements should also be provided for transparency purposes, as it would reflect the actual volume of resources eventually transferred to the recipient. 


\title{
6. TOSSD pillar I: cross-border resource flows in support of sustainable development
}

\author{
6.1. Scope of cross-border resource flows pillar (\$39-42 of the reporting \\ instructions)
}

39. The cross-border resource flows pillar covers resources extended to TOSSD-eligible recipient countries in support of sustainable development by bilateral and multilateral providers (Figure 2). The major breakdown is between grants and in-kind contributions on the one hand, and financial transactions on the other hand. Concessional and non-concessional transactions are separately identifiable. Resources mobilised from the private sector by official interventions are also included. However, they are presented under a separate heading as the funds do not necessarily originate from the provider country and may even be domestic i.e. originate from the recipient country.

Indonesian stakeholders provided their views on specific items, which are of particular interest because of the difficulty to assess whether they should be TOSSD-eligible and/or in which Pillar they should be included:

\section{Development-oriented social and cultural programmes}

According to Indonesian stakeholders, cultural programmes could be considered as support to sustainable development as long as the recipient government is involved in the organisation or financing of the event. The contribution of culture to sustainable development is recognised in the SDGs ${ }^{35}$. In addition, in the case of Indonesia, there can be a link between cultural programmes and environmental sustainability, further justifying their inclusion in TOSSD (for example support to some local practices that are supportive of the environment and sustainable development such as "local wisdom" in the area of agricultural irrigation). However, it might be difficult to collect information on activities carried out by local Indonesian authorities (e.g. co-operation by Indonesian local authorities with those of other countries).

\section{Scholarships/imputed student costs}

Stakeholders generally confirmed that scholarships funded by external providers to Indonesian students should be recorded in Pillar I. According to the Ministry of National Development Planning/Bappenas, most

\footnotetext{
${ }^{35}$ For example through SDG target 4.7, which states "By 2030, ensure that all learners acquire the knowledge and skills needed to promote sustainable development, including, among others, through education for sustainable development and sustainable lifestyles, human rights, gender equality, promotion of a culture of peace and nonviolence, global citizenship and appreciation of cultural diversity and of culture's contribution to sustainable development." or SDG target 11.4, which states "Strengthen efforts to protect and safeguard the world's cultural and natural heritage".
} 
students studying abroad thanks to scholarships return to Indonesia after their studies. However, they do not consider imputed student costs (which are indirect costs of tuition in provider countries to nationals of TOSSD-eligible countries) as support to Indonesia. Consequently, these costs should not be included in Pillar I.

However, it is worth noting that CSOs did not consider that scholarships granted to Indonesians should be considered as support to Indonesia, because the money is spent in the provider country. Indonesia does provide scholarships to students from other countries.

\section{Private finance mobilised}

Indonesia very much supported the inclusion of private finance mobilised in the TOSSD framework, even though the country does not use leveraging instruments as part of its development co-operation. However, as a recipient, data on private finance mobilised in Indonesia would be available at the PPP unit of the Ministry of National Development Planning/Bappenas,

\section{Debt Relief}

According to the Ministry of Finance, since 2000, Indonesia benefited from two debt relief operations: a rescheduling within the framework of the Paris Club and a debt swap. Interviewees considered that debt relief constitutes support to recipient countries and should be included in TOSSD.

\section{Export credits}

From the interviews carried out, it emerged that Indonesia provides export credits to other developing countries. The Indonesian EXIMBANK indicated that they have developed a model to measure the impact of all sustainable development instruments in Indonesia (e.g. on job creation, social indicators, reduction of poverty, etc.). The developmental impact on recipient countries can also be measured and is part of the project selection criteria. In addition to supporting Indonesian exports, the Indonesian EXIMBANK finances some co-operation projects with other EXIMBANKs in developing countries, for example EXIMBANK Africa.

\section{Presentation of flows in TOSSD}

CSOs insisted that official and private flows be presented separately in TOSSD, to avoid confusion between flows which are of very different nature. Interviews with Indonesian officials confirmed that this separation was indeed necessary, not only for transparency purposes but also to strengthen the accountability of the different financing actors.

\section{Usefulness of TOSSD Pillar I for Indonesia as a recipient of financing for sustainable development}

Indonesia advocated for capturing in TOSSD the full range of instruments available for sustainable development. Indonesia estimates that its national budget can only finance $25 \%$ of its next development plan 2020-24. TOSSD can support Indonesia in identifying additional resources that can complement national budget resources. Indonesian officials highlighted two main areas where TOSSD could particularly help in this regard:

- Cross-country comparisons: Indonesia puts great emphasis on innovative financing (blended finance, Islamic finance for sustainable development, etc.) and is interested to know what kind of schemes other countries use to support their own national development processes. Indonesia is also interested in knowing the financial terms and concessionality levels of support provided to other recipient countries. TOSSD could help in providing information on these schemes.

- Tracking private finance: Indonesia has specific interest on private finance for sustainable development and would like to use official finance to catalyse private sector participation. Many Indonesian stakeholders emphasised that the key information gap is on private finance for sustainable development. Furthermore, they pointed out that TOSSD could be of great use to 
Indonesia if it could provide information on private finance, including the different types of private resources available (e.g. philanthropy) and mobilisation schemes (see Section 6.5).

41. In the TOSSD system, multilateral providers report on activities that they undertake (including both unearmarked and earmarked allocations i.e. $B+C+D$ in Figure 3 ). The original source of funds can be official providers (through core contributions or pooled funds) or the private sector (through funds raised in the international capital markets or private charitable contributions to multilateral organisations). In the case of funds for which a multilateral institution only provides Trustee services, the organisations implementing the activities, and not the Trustee institution, should report on TOSSD.

42. In the case of trust funds managed by several multilateral organisations, it should be considered, on a case-by-case basis, which institution is better placed to report on TOSSD outflows, usually the lead institution.

Indonesian stakeholders confirmed that it was challenging for them to track the final use of their contributions to trust funds. As such, TOSSD could help provide information on expenditures by these trust funds.

\section{Triangular co-operation (\$43-44 of the reporting instructions)}

43. Triangular co-operation involves a partnership among three partners, two of which are TOSSDeligible countries (Figure 4):

- The beneficiary partner that requests support to tackle a specific development challenge.

- The pivotal partner that has proven experience in tackling the issue, and shares its resources, knowledge and expertise to help others do the same.

- The facilitating partner that helps connect the partners, supporting the collaboration financially and technically.

44. The pivotal and facilitating partners each report on the resources they provide.

Indonesia has a wide experience in managing triangular co-operation projects as shown in the yearly reports produced by the country on South-South and Triangular Co-operation (See for example (National Coordination Team of SSC, 2018[32])).

Indonesia agreed with the way the various roles (beneficiary, pivotal partner and facilitating partner) were described in the definition. However, Indonesia's experience shows that the division of roles can be flexible depending on the project and that the number of parties might be higher than three. As an example, in the co-operation between the Ministry of National Development Planning/Bappenas, the MoVillage, UNOSSC, and the Korean Facility (universities consortium) under the Village Development Innovation Programme, Indonesia also contributes financially as a beneficiary party through a co-funding mechanism. The cooperation also involves more than three parties as several government, academic and multilateral institutions are involved.

Therefore, Indonesia suggested to slightly modify the formulation of paragraph 43 as follows "Triangular co-operation involves a partnership among at least three partners, two of which are TOSSD-eligible countries (Figure 4)". ${ }^{36}$

\footnotetext{
${ }^{36}$ In the meantime, the definition of triangular co-operation has been discussed at the $10^{\text {th }}$ meeting of the TOSSD Task Force (see Action Points of the meeting on the TOSSD Task Force web page: http://www.oecd.org/dac/financingsustainable-development/development-finance-standards/tossd-task-force.htm). The suggestions made by Indonesia were included in the version of the Reporting Instructions dated February 2020.
} 


\subsection{Eligibility criteria regarding sustainable development (\$47-49 of the Reporting Instructions)}

47. In the context of TOSSD, an activity is deemed to support sustainable development if it directly contributes to at least one of the SDG targets as identified in the official list of SDG targets developed and maintained by the United Nations Statistical Commission (UNSC) and if no substantial detrimental effect is anticipated on one or more of the other targets.

48. There may be cases where reporters cannot find a direct link with one of the SDG targets. This is due to the fact that SDG targets represent a global ambition and may therefore not encapsulate all dimensions of a given developmental issue in their final agreed wording.

49. If a reporter cannot find a direct link between one of its activities providing a critical contribution to sustainable development and an SDG target, the reporter will still be able to report it, linking it to a goal and providing an appropriate justification.

Indonesia is strongly committed to implement the SDGs. 94 targets of the SDG global indicator framework were included in the National Midterm Development Plan (RPJMN) 2015-2019 and the RPJMN 2020-2024 included 118 targets of the global indicator framework. Even official institutions such as BAZNAS aim to align and link their activities with the SDGs, whether the resources are allocated nationally or abroad through international development co-operation. Indonesia also added indicators related to the $4^{\text {th }}$ dimension of inclusive governance, notably the Indonesia Democracy Index ${ }^{37}$.

As regards the level at which the eligibility criteria should be linked to the SDGs (para 47 above), two different sets of views were expressed during the pilot study:

- Some indicated that the proposed level (i.e. an activity can be included in TOSSD if it can be directly linked to an SDG target) seems the most relevant one.

- Other stakeholders indicated that the criteria should not be at the target level (too broad), but at the indicator level. The mission team indicated that the International TOSSD Task Force had discussed this issue and noted that SDG indicators still had many gaps and were sometimes oversimplified to be helpful in the context of a global reporting exercise such as TOSSD. ${ }^{38}$

An example taken by one stakeholder was that the criteria should make it possible for the reporter to identify whether the re-use of palm oil waste for producing energy is TOSSD-eligible (knowing that the culture of palm oil can be seen as unsustainable). Another example was whether support to the reduction of emissions of coal-fired power plants should be eligible.

On paragraph 48 above, the National SDGs Secretariat indicated that, among the activities considered by Indonesia as supporting the SDGs, it has not faced cases where it cannot find a direct link with one of the SDG targets and will be interested in seeing these cases.

\section{Other relevant elements that emerged from the pilot included:}

- Some stakeholders expressed the view that TOSSD should record unsustainable activities, so that these can be highlighted and their eligibility discussed at the policy level with a view to agreeing more stringent eligibility rules internationally.

\footnotetext{
37 For more information on the Indonesia Democracy Index, see: https://www.id.undp.org/content/indonesia/en/home/operations/projects/democratic governance/indonesiandemocracy-index--idi--project.html

38 See the action points of the first meeting of the TOSSD Task Force at: http://www.oecd.org/dac/financingsustainable-development/development-finance-standards/TOSSD-meeting-action-points.pdf
} 
- To avoid double counting and for analytical purposes, Indonesia identifies in its National SDG Action plans "the main intention" of the activity. The TOSSD Task Force already discussed the issue of reporting multiple targets and deemed that it was necessary to indeed record several targets in TOSSD to provide a comprehensive picture of how an activity supports the SDGs.

- Indonesia has been actively working on the issue of positive and negative interlinkages between targets (Ministry of National Development Planning/Bappenas, 2019[1]). This work has shown that there is often a trade-off to accept between targets (e.g. on the issue of building infrastructure against the reduction in the availability of land). The RPJMN 2020-2024 has been developed with an analysis of the impact of one target over another.

\section{Overall, based on the comments by Indonesia, the mission team felt that the TOSSD Task Force may wish to:}

- Further deepen the concept of sustainability and how it could be operationalised in TOSSD. It was proposed to map a selection of externally financed activities against SDG targets to test if the TOSSD methodology above is sufficiently operational.

- Further define eligibility criteria for specific cases (e.g. coal-fired power plants, palm oil, etc.).

- Reflect on the benefits and drawbacks of recording potentially unsustainable activities to feed policy discussions on the TOSSD eligibility rules.

- Provide a casebook of activities that cannot be linked to SDG targets.

\subsection{TOSSD-eligible countries (§50-51 of the Reporting Instructions)}

50. To count as TOSSD, an activity should involve a cross-border resource flow to a country on the List of TOSSD recipient countries. For any reporting year, this List includes:

i. All countries and territories that are present on the "DAC List of ODA recipients".

ii. Other countries and territories that have activated the TOSSD opt-in procedure.

51. Any country or territory can activate the opt-in procedure at any point in time. The procedure is voluntary but needs to be motivated through the specific economic, social or environmental context that the country faces. Traditional donors are expected to not use the TOSSD opt-in procedure.

Indonesia considers that country eligibility based on income per capita is too restrictive. Although Indonesia has become an upper middle-income country in 2020, the Government still estimates that it has large financing needs. Therefore, Indonesia supports the opt-in procedure proposed in TOSSD.

\subsection{Measurement of technical co-operation (\$53-57 of the Reporting Instructions)}

53. The implementation of technical co-operation activities may involve hiring experts or consultants in the international markets or deploying public officials of provider countries. In the first case, TOSSD records the costs incurred by the provider because those costs are already internationally comparable in monetary terms; in the second case a specific methodology is used to estimate the costs in an internationally comparable manner.

Experts contracted in the market

54. If experts are hired in the market, the price of the contract will be recorded in TOSSD, regardless of the country of residence of the expert.

In-kind technical co-operation 
55. In-kind technical co-operation is defined as technical co-operation implemented using public officials of the reporting country.

56. Given the differences in salary levels of public officials across countries, the value of in-kind technical co-operation is calculated by applying the purchasing power parity (PPP) conversion factor for private consumption to the salary costs of the public official(s) involved in the technical co-operation activity. The reporting country provides data on the salary costs corresponding to time actually spent by the official(s) in the recipient country, including time spent on preparation and follow-up. The PPP calculation is made by the Secretariat collating TOSSD data for all countries.

57. Other expenses related to the implementation of in-kind technical co-operation, which include all costs incurred to deploy the official, such as flights, per-diem, accommodation, internal transportation within the recipient country and training, are also included in TOSSD. These expenses are reported separately from the salary costs, and the PPP factor is not applied.

Indonesia considers in-kind technical co-operation as key for sustainable development as it allows to share expertise and good practices among countries. Indonesia does not currently measure this co-operation in financial terms, because there is no finalised standard method to monetise it. A number of stakeholders also emphasised that monetising this co-operation risks providing a partial picture of Indonesia's contribution to sustainable development, which should also be looked at through actual results obtained in the recipient country. This is why the National SDG Action Plan ${ }^{39}$, which aims to mainstream the SDGs in the national development agenda, has provided the possibility for all actors (e.g. official institutions, CSOs, private sector) involved in the preparation of the plan, to monetise their support or to provide more qualitative information (in terms of inputs, such as the number of workshops conducted, or in terms of outputs, such as the number of people trained).

The MOF is currently developing a standard cost estimation for in-kind technical co-operation delivered by Indonesian officials in the context of SSC (e.g. salary, transportation). The cost estimation is based on a number of variables such as the duration of the assignment, the salaries applied in embassies.

The Indonesian officials involved in the measurement of South-South co-operation (e.g. the Ministry of Finance) expressed interest in the TOSSD methodology for measuring in-kind technical co-operation and indicated that they would further study it to see to what extent it could be used in the context of IndonesianAID. The TOSSD approach, based on a PPP estimation, was seen as useful complement to the national currency-based estimation, as it would allow to compare the actual cost of technical co-operation across countries.

\subsection{Measurement of resources mobilised from the private sector ( $\$ 58-59$ of the reporting instructions)}

58. Mobilisation (or leveraging) refers to the ways in which specific mechanisms stimulate the allocation of additional financial resources to particular objectives; it requires a demonstrable causal link between finance made available for a specific project and the leveraging instrument used.

59. TOSSD measures the resources mobilised by official development finance interventions from private sources, where a causal link between the provision of the private finance and the official intervention can be documented. Transactions are classified as official or private according to who owns or controls the financing entity. Any resources mobilised from public entities should be excluded from the mobilisation measure.

${ }^{39}$ See the English version in: http://sdgs.bappenas.go.id/dokumen/, accessed on 13/08/2020. 
The in-country mission of the pilot showed that Indonesian stakeholders are very interested in the mobilisation of private finance for sustainable development. This stems from the recognition that public resources will not be sufficient to achieve the SDGs.

There are a number of initiatives by the Government to catalyse private finance in Indonesia. One example is the PINA Scheme ${ }^{40}$ which is a plan by the Government to match projects (mainly from state-owned enterprises) with companies that have funds to invest. Another example is the SDG financing Hub, a new platform that will look at financing beyond official resources to finance the SDGs in Indonesia. The Ministry of National Development Planning/Bappenas will be involved in match-making between government projects and the financing identified in the Hub. The platform is currently being established and an MOU was signed in October 2019 with the Asian Venture Philanthropy Network (AVPN) to support the SDG Financing Hub. The Network will support the Government on a pilot to determine how the Government can find potential private sector partners for projects and how to elaborate a campaign for this purpose. The MOU will also help the Government to create a database of bankable projects.

Another example of official intervention mobilising private finance is the one by BAZNAS, the national Zakat agency. In addition to the Zakat funds collected by BAZNAS itself (and that would be considered "official" in the context of TOSSD), this agency has the mandate to approve, control and regulate the private Zakat institutions (Laznas). Through this mandate, BAZNAS sees itself as contributing to the mobilisation of private Zakat funds. In addition, the private Zakat institutions need to report all of their activities to $B A Z N A S$, and these activities are tagged against the SDGs when relevant.

However, the study showed that, overall, stakeholders were not very familiar with the concept of private finance mobilised. There is no data collection on private finance mobilised in Indonesia, neither by providers nor by the Government, with the exception of the Public-Private Partnerships (PPP) Directorate at the Ministry of National Development Planning/Bappenas, which tracks private investments mobilised in Indonesia in the context of the PPP schemes. However, out of the 14 ongoing PPP projects at the time of the in-country mission, only two (a central coal-fired power plant in Java and a toll road) have involved external resources. Most PPP projects involve only national government funding along with that of the private sector, even though the private sector may sometimes call on international organisations to provide financing for the project. At this stage, alignment with the SDGs is not a criterion for setting up PPP projects in Indonesia.

As a provider of development co-operation, Indonesia does not currently use leveraging instruments (e.g. guarantees). Therefore, Indonesia has no data to report on private finance mobilised through official development interventions in support of the sustainable development of other countries.

Having information on private finance mobilised, both domestically and as a provider of development cooperation, would be interesting for the following processes:

- For the government as a whole, to valorise its efforts in line with international commitments made in the Addis Ababa Action Agenda and the SDG framework to mobilise additional resources for development.

- For the National SDGs Secretariat, to inform national SDG targets and show efforts by Indonesia in mobilising the private sector for sustainable development.

- For the Ministry of National Development Planning/Bappenas in the process of development planning: TOSSD data on 2019 flows, to be made available online in December 2020, would be useful for the planning of activities in 2022 and 2023. The type of information that would interest the Ministry of National Development Planning/Bappenas is how financing packages are put together (e.g. blended finance packages, how risk mitigation instruments are used) and the amounts, both in Indonesia but also in other countries as benchmarks.

${ }^{40}$ See: http://pina.bappenas.go.id/ 


\section{Regional and global expenditures in support of sustainable development and review of Annex E of the TOSSD Reporting Instructions}

This section reflects the perspective of Indonesia on TOSSD Pillar II. It covers chapter 3 and Annex E of the TOSSD Reporting Instructions (International TOSSD Task Force, 2019 $9_{[2]}$ ). Chapter 3 provides the broad definition of TOSSD Pillar II and Annex E provides the eligibility criteria for specific items. Although the main focus of Annex E is on TOSSD Pillar II, it also covers some eligibility criteria for Pillar I activities, in particular on peace and security. The comments made by Indonesia on these eligibility criteria are also reflected in this section to keep consistency with the structure of the TOSSD Reporting Instructions.

This section focuses only on the perspective of Indonesia on the TOSSD Reporting Instructions. Further information on public finance for international public goods and the capacity of Indonesia to report on these expenditures in TOSSD can be found in Chapter 10. .

\subsection{TOSSD Pillar II: regional and global expenditures in support of sustainable development}

\subsubsection{Scope of flows relevant for Pillar II}

64. One of the key characteristics of the SDGs is their universality. The 2030 Agenda calls for all countries to "work to implement the Agenda within [their] own countries and at the regional and global levels". The Pillar II of TOSSD covers global and regional expenditures provided in support of IPGs and development enablers and/or to address global challenges (as defined in section 1.1). It includes activities whose benefits are of transnational reach.

70. Pillar II will include resources provided at two levels:

Activities of multilateral, global or regional, institutions that promote international co-operation for sustainable development (e.g. norm-setting, international oversight, knowledge generation and dissemination).

- $\quad$ Certain expenditures incurred by providers in their own countries or in non TOSSD-eligible countries (e.g. research and support to refugees).

Indonesian stakeholders supported the view that a number of activities undertaken at a global or regional level (e.g. norm-setting, international surveillance, etc.) do contribute to sustainable development and as such should be tracked in TOSSD, if the measure is to be global and 
comprehensive. The following examples were provided to illustrate the relevance of regional and international action for sustainable development:

- The Asia-Europe Environment Forum ${ }^{41}$ which provides an inter-regional platform for knowledgesharing and capacity building for policy makers, businesses and civil society from Asia and Europe on sustainable development.

- International surveillance of communicable diseases.

- The Asia Pacific Roundtable for sustainable consumption. ${ }^{42}$

Indonesia also supported the inclusion in TOSSD of domestic expenditures that support the provision of International Public Goods (IPGs), recognising that these expenditures will be key for the achievement of many SDGs. Indonesian stakeholders emphasised the role of domestic climate actions or medical innovations resulting from national $R \& D$, for example on communicable diseases, which can bring huge gains for global sustainable development. Indonesia did not perceive any political sensitivities related to the inclusion in TOSSD of domestic expenditures that support SDG-relevant IPGs.

However, the interview carried out with a representative from CSOs in Indonesia indicated that they would not be in favour of including global and regional activities (e.g. international conferences on climate, etc.). The reason is that this would inflate positive contributions to the SDGs by providers while no accounting is made of the negative contribution to sustainable development by these same providers.

\subsubsection{Delineation between Pillar I and Pillar II}

67. Cross-border flows to recipient countries can also support IPGs or development enablers or address global challenges. However, given that a key objective of TOSSD is to enhance transparency of external finance for sustainable development provided to recipient countries, such activities will be categorised in Pillar I.

68. When the provider first commits funds to a regional programme, and decides on their allocation by country only at a later stage, both the original regional commitment and the subsequent disbursements by country should be reported in Pillar I. Multi-country activities, i.e. activities that result in cross-border flows to several countries belonging to the same region, are also reported in Pillar I using regional recipient codes.

Many cross-border flows to TOSSD-eligible countries (TOSSD Pillar I) can also support the provision of international public goods (TOSSD Pillar II), for example foreign assistance in climate mitigation or medical research. Indonesia agreed with the classification of these activities in TOSSD Pillar I rather than Pillar II as providing transparency on the cross-border nature of the flows needs to be prioritised. Pillar II should include regional and global expenditures which are not aimed at supporting specific recipients. Stakeholders also recommended to clarify and provide examples on multi-country activities.

\footnotetext{
${ }^{41}$ http://www.asef.org/projects/programmes/517-asia-europe-environment-forum-(envforum)

${ }^{42}$ http://www.aprscp.net/
} 


\subsubsection{Specific eligibility criteria for TOSSD Pillar II}

70. In addition, for including an activity in TOSSD pillar II, it needs to:

- Provide substantial benefits to TOSSD-eligible countries or their populations, and/or

- Be implemented in direct co-operation with TOSSD-eligible countries, or private or public institutions from these countries, as a means of ensuring the benefit to TOSSD-eligible countries or their populations.

71. The first criterion is meant to exclude public investments that exclusively or overwhelmingly benefit provider countries' own populations. In particular, support for domestic activities whose benefits are only shared by the population of the provider country (e.g. primary education, climate adaptation) are not eligible to TOSSD. The second criterion recognises the importance of international co-operation, in particular the involvement of developing countries in global issues, as put forward by the 2030 Agenda. In the case of multilateral organisations, "direct co-operation with TOSSD-eligible countries" is presumed when some TOSSD-eligible countries are members of the organisation.

A representative of the Ministry of National Development Planning/Bappenas questioned the specific eligibility criteria for Pillar II and did not think that they would be sufficiently operational. The official recommended that clarifications be made regarding the criterion that activities need to provide "substantial benefits to TOSSD-eligible countries or their populations".

\subsection{Review of Annex E on additional guidance on the eligibility of specific themes}

\subsubsection{Research \& development (R\&D)}

As part of the SDGs, countries have pledged to substantially increase public and private Research \& Development (R\&D) spending as well as the number of researchers by 2030 . $R \& D$ is one of the priorities identified by Indonesia in the context of both its national development and the achievement of the SDGs. The Government is trying to step up its efforts to support it (see section 10.1.1). Under certain eligibility criteria specified in Annex E of the Reporting Instructions (International TOSSD Task Force, 2019[2]) and provided in the below box, national $R \& D$ spending is considered as a contribution to international public goods and is reportable in TOSSD Pillar II.

R\&D activities ${ }^{43}$ carried out in the provider country, in a non-TOSSD-eligible country or at the level of a multilateral institution are eligible for reporting under TOSSD Pillar II provided that:

a) The research subject is SDG-related and potentially applicable to more than one country, including at least one TOSSD-eligible country, or the research subject is related to basic research. The first criterion is meant to exclude R\&D that is relevant to the SDGs, but for which the applicability is largely domestic.

b) In the case of scientific publications and research data, the funder institution's public access policy is based on the principle of open access. This will ensure that results of the research are put in the public domain and therefore available for populations and scientists worldwide, including in TOSSD-eligible countries.

c) In the case of official support for experimental development, the activity is eligible provided that it meets one of the following conditions:

43 This is related to targets 2.a., 3.b., 7.a, 7.b., 9.b, 14.a, 17.6, 17.8. Definitions in this section are taken from the Frascati Manual available at: http://www.oecd.org/sti/frascati-manual-2015-9789264239012-en.htm. 
- $\quad$ The results of the R\&D activity are expected to be put in the public domain, for example through applied public research.

- Research contracts are associated with conditions that aim at promoting competitive manufacturing, for example through non-exclusive licensing.

The support consists of schemes such as Advanced Market Commitments (AMC) which aim at developing a product at low prices.

In addition, cases where R\&D is followed by an activity that promotes access to a product in developing countries, both the promotion activity and the original $R \& D$ activity are eligible.

The criteria aim to ensure that R\&D activities with potential transnational applicability provide benefits to populations and scientists in TOSSD-eligible countries, by requiring that the results of the R\&D activity be available to them and/or by promoting the access to innovation and technologies in these countries.

\section{Perspective of Indonesia on the TOSSD eligibility criteria}

Indonesia confirmed the relevance of including in TOSSD Pillar II international and domestic R\&D expenditures to the extent that these provide transnational benefits.

In terms of publicly-funded $R \& D$ resulting in scientific publications, Indonesia supported the validity of the criterion requiring that the publications should be based on the principle of open access to be eligible to TOSSD. Several stakeholders emphasised that if the results of R\&D carried out in other countries are freely available to Indonesian researchers, this can support sustainable development in Indonesia. Some interviewees also suggested to include in TOSSD incentives for publishing articles and data in several languages, and at a minimum in English, to ensure that the benefits are truly transnational. Indonesia does apply the principle of open access to publicly-funded scientific publications, which is stipulated in the Openness of Public Information Law (No.14 of 2008).

In terms of implementation of the principle of open access, the Ministry of Research and Technology created in 2017 the Science and Technology Index (SINTA), an open access publication indexing system aimed at measuring the performance of Indonesian researchers and capturing the full array of scientific publications in Indonesia. In terms of publication language, there is no obligation in Indonesia to publish the articles in English and the majority are published in Indonesian. However, through its evaluation system which also takes into account the publication of articles in international journals, the Government is also trying to incentivise publications in English. Complementary to SINTA, the GARUDA PORTAL is a web database that provides open access to content from higher education institutions and other research institutions, as well as publications that were publicly funded in Indonesia. In addition, some government institutions, such as the Ministry of Health, publish the scientific articles resulting from their R\&D directly on their website.

Regarding the TOSSD eligibility criteria for experimental development ${ }^{44}$ Indonesia made a number of comments.

In terms of policies and schemes that aim at developing products at low prices and facilitating in particular the access to medicines, in 2018 the Ministry of Law and Human Rights (MLHR) issued a Ministerial

\footnotetext{
${ }^{44}$ According to the Frascati Manual, experimental development is "systematic work, drawing on knowledge gained from research and practical experience and producing additional knowledge, which is directed to producing new products or processes or to improving existing products or processes." available at: http://www.oecd.org/sti/frascatimanual-2015-9789264239012-en.htm
} 
Regulation ${ }^{45}$ that gives the Ministry the power to grant compulsory licences to produce, import and export patented products needed to treat human diseases in Indonesia and/or in third countries lacking pharmaceuticals manufacturing capacity, upon the request from these countries. According to the definition of the World Trade Organisation (WTO), "compulsory licensing is when a government allows someone else to produce a patented product or process without the consent of the patent owner or plans to use the patent-protected invention itself" ${ }^{46}$. Under the previous regulation, ${ }^{47}$ compulsory licensing in Indonesia was only possible for the purposes of supplying the domestic market. The rationale behind the use of compulsory licences is based on humanitarian principles. Indonesia also recalled that the use of compulsory licensing for medicines is aligned with the provisions of the WTO TRIPS Agreement (in particular articles 7 and 31) as well as the interpretation of the 2001 Doha Declaration on the TRIPS Agreement and Public Health, which reaffirmed that "the Agreement can and should be interpreted and implemented in a manner that supports WTO Members' right to protect public health and, in particular, to promote access to medicines for all." In addition, the use of compulsory licensing is also in line with SDGs 1 and 3, goals to which Indonesia actively contributed. So far, Indonesia has granted three compulsory licenses, which all were government use compulsory licenses granted under the previous regulation and for the purposes of supplying the domestic market. The compulsory licenses were related to antiviral and antiretroviral treatments for HIV. In terms of compensation of the patent holder, Indonesia always proposes $0.5 \%$ of the sales, although the proposal is not always accepted.

Although distinct from the R\&D activity itself, the issue of compulsory licensing, and more broadly the socalled TRIPS flexibilities, was discussed at the $7^{\text {th }}$ TOSSD Task Force meeting under the item "Science, Technology and Innovation" (Bejraoui and Benn, 2019[33]). The use of compulsory licenses for the purposes of exporting lower-priced medicines to TOSSD-eligible countries is fully aligned with the SDGs, as emphasised in SDG target 3.b., ${ }^{48}$ and as such could be eligible to TOSSD. This view was also supported by Indonesia. A methodology for accounting the use of compulsory licenses in TOSSD could be discussed at a later stage by the TOSSD Task Force, although it should be noted that, so far, this TRIPS flexibility has been used only once. ${ }^{49}$ In 2007, the Canadian Government granted a compulsory licence to a Canadian generic manufacturer for the purposes of exporting antiretroviral medicines to Rwanda.

\subsubsection{Environmental sustainability}

Annex E of the TOSSD Reporting Instructions provides the eligibility criteria for counting domestic climate change actions in Pillar II. Although the treatment of biodiversity activities in TOSSD had not yet been addressed by the Task Force at the time of the mission, this topic was discussed during the country mission given the potential of Indonesia as a provider of global biodiversity.

\footnotetext{
45 The Ministerial Regulation No. 39/2018 concerning the Procedures for Granting of Compulsory Licensing (CL) was issued in 2018. Since then, it has been replaced by the Ministerial Regulation No.30/2019 regarding the procedures for Compulsory Licensing. These regulations are part of the implementing regulations of the Patent Law (Law 13/2016) which provides the mandate for compulsory licences.

46 https://www.wto.org/english/tratop e/trips e/public health faq e.htm

${ }^{47}$ Regulation 14/2011

48 SDG target 3.b calls for the provision of "access to affordable essential medicines and vaccines, in accordance with the Doha Declaration on the TRIPS Agreement and Public Health, which affirms the right of developing countries to use to the full the provisions in the Agreement on Trade-related Aspects of Intellectual Property Rights regarding flexibilities to protect public health, and, in particular, provide access to medicines for all"
}

49 https://www.bmj.com/content/365/bmj.I2098 


\section{Climate change}

The 2030 Agenda includes specific climate change targets and indicators, while recognising that the primary international, intergovernmental forum for negotiating the global response to climate change is the United Nations Framework Convention on Climate Change (UNFCCC). TOSSD does not by any means intend to replace reporting on climate actions to UNFCCC or other relevant organisations. The objective is rather to support greater transparency of climate-related activities.

Cross-border resource flows related to mitigation and adaptation activities in TOSSD-eligible countries are reportable in pillar I. Verify their eligibility against general TOSSD eligibility criteria.

Climate actions that convey transnational benefits (at global or regional levels) are included in pillar II.

- $\quad$ Activities carried out by multilateral institutions are eligible, regardless of whether the institution has combatting climate change as its main objective or one of its objectives.

- Climate actions in the provider country, or in a non TOSSD-eligible country, and that convey transnational benefits are also eligible for TOSSD. In particular:

- $\quad$ Research and knowledge creation on climate change mitigation and adaptation is eligible if it complies with TOSSD eligibility criteria for R\&D in general, which aim to ensure that results of the research are available for populations and scientists worldwide.

- Protection and/or enhancement of greenhouse gas (GHG) sinks and reservoirs (e.g. carbon capture and storage, reforestation) is eligible as it directly contributes to the removal of GHGs from the atmosphere, benefitting all countries of the world.

- Activities that limit anthropogenic emission of GHGs, including gases regulated by the Montreal protocol, are eligible in principle. The modalities for the accounting of these expenditures should be further discussed with stakeholders and climate bodies, as such activities convey global benefits, but also pursue other objectives such as energy generation, transport or the protection of the local environment.

Climate adaptation actions in the provider country or in a non TOSSD-eligible country are generally excluded from TOSSD, given that adaptation is essentially a localised activity. If adaptation activities can be demonstrated to produce substantial benefits to TOSSD eligible countries, they can be included.

Indonesia was a particularly pertinent country for discussing the treatment of activities supporting environmental sustainability in TOSSD. For Indonesia, the three concepts of climate mitigation, climate adaptation and biodiversity should be viewed in an integrated manner. For example, in Indonesia, deforestation is a major driver of both greenhouse gas emissions and biodiversity loss. Combating climate change is a high priority for Indonesia as it is one of the countries most likely to be affected by the rise in sea levels ${ }^{50}$ and climate-induced disasters. ${ }^{51}$ On this basis, the Government made a number of commitments to step up its climate change mitigation and adaptation priorities (see section 10.1.2 for information on environmental policies and public climate finance in Indonesia). Indonesia is also host of the third largest rainforest area in the world and one of the richest biodiversity in the globe.

\footnotetext{
50 Indonesia is an archipelagic country with extensive low-lying and small island areas.

51 Indonesia has already experienced extreme climate events such as floods and drought. According to its Indonesia's 2016 Nationally Determined Contribution, "climate change is believed to increase the risk for hydro meteorological disasters, which make up to $80 \%$ of disaster occurrences in Indonesia."
} 
Perspective of Indonesia on the TOSSD eligibility criteria

Indonesia fully supports the principle of including in Pillar II activities undertaken at the multilateral (e.g. norm-setting) and domestic (e.g. reduction of GHG emissions) level aimed at combating climate change as these activities are an integral part of global efforts to achieve the SDGs. As stated in its first Nationally Determined Contribution, "Indonesia also views its development pathway towards low carbon and climate resilience is consistent with its commitment to contribute to the global effort for achieving Sustainable Development Goals (SDGs)" ${ }^{52}$. Moreover, given the particular vulnerability of Indonesia to climate change, the country considers global efforts to combat climate change as key for its sustainable development.

In terms of climate mitigation, Indonesia recommends both the inclusion of activities aimed at protecting and/or enhancing greenhouse gas (GHG) sinks and reservoirs and activities aimed at limiting anthropogenic emissions of GHGs, as they are both key for effective reduction of GHG emissions. In addition, Indonesia considers climate mitigation and adaptation efforts as an integrated concept and advocated for the inclusion of climate adaptation in TOSSD Pillar II. The officials interviewed did not agree that climate adaptation entails only local benefits; it can also provide transnational benefits by preventing migration and displacements of populations, decreasing economic uncertainty for foreign investment, strengthening ecosystems and preserving biodiversity. Climate adaptation is very important for Indonesia as the country is particularly vulnerable to global warming and climate change ${ }^{53}$.

\subsubsection{Peace and security (SDG target 16.a.)}

Indonesia is a particularly relevant country for testing the TOSSD eligibility criteria related to peace and security. In 2018, Indonesia was elected as a non-permanent member of the United Nations Security Council (UNSC). In addition, Indonesia is both a recipient and a provider of peace and security cooperation. Indonesia receives support in areas such as Security Sector Reform, counter-narcotics and counter-terrorism. As a provider, Indonesia is committed to contribute to international peace and security based on "independence, eternal peace and social justice", as stipulated in its Constitution. ${ }^{54}$ Historically, this commitment has been reflected in Indonesia's participation in, and contribution to, UN peacekeeping operations, which constitute today one of the top priorities of Indonesia's non-permanent membership in the UN Security Council 2019-2055. In particular:

- Indonesia aims to be a top-ten contributor to UN peacekeeping forces ${ }^{56}$. Currently Indonesia is ranked eighth with a contribution of 2852 peacekeepers in 9 UN Peace Operations (figures as of March 2020).

\footnotetext{
${ }^{52}$ See page 11 of the 2016 Nationally Determined Contribution of Indonesia https://www4.unfccc.int/sites/ndcstaging/PublishedDocuments/Indonesia\%20First/First\%20NDC\%20Indonesia sub mitted\%20to\%20UNFCCC\%20Set November\%20\%202016.pdf

${ }^{53}$ https://www.env.go.jp/en/earth/ap-net/documents/seminar/22nd/18 Indonesia Virgiyanti.pdf

${ }^{54}$ See paragraph IV of the Opening of the 1945 Constitution of the Republic of Indonesia.

${ }^{55} \mathrm{https}$ ://kemlu.go.id/portal/en/read/91/halaman list lainnya/indonesia-and-the-united-nations-peacekeepingmission

${ }^{56} \mathrm{https}: / / w w w . t h e j a k a r t a p o s t . c o m / n e w s / 2019 / 01 / 24 /$ indonesia-committed-to-greater-peacekeeping-contribution-fmretno.html
} 
- Indonesia puts great emphasis on appropriate pre-deployment trainings and capacity-building for UN peacekeepers57. The Peace Forces Training Centre located in Indonesia provides trainings both for Indonesian and non-Indonesian peacekeepers.

- Indonesia emphasises also the importance of regional approaches to peace and security.

\section{Perspective of Indonesia on the TOSSD eligibility criteria}

Indonesia considers peace and security as key for sustainable development and confirms the relevance of including peace and security expenditures in TOSSD. After the election of Indonesia as a non-permanent member of the UN Security Council in June 2018, the Minister for Foreign Affairs of Indonesia Retno L.P. Marsudi made a speech where she highlighted four priorities, one of which is the need to foster the linkages between sustaining peace and sustaining development, particularly the 2030 Agenda ${ }^{58}$. Interviews undertaken with officials from the Ministry for Foreign Affairs confirmed this view.

\section{General principles and safeguards governing the eligibility of peace and security activities in TOSSD}

Commitment to do no harm: Activities included in TOSSD should be based on the "do no harm" principle, meaning that both the intended and unintended consequences of interventions should be taken into account in the activity design with the aim of ensuring "no harm" to populations. In particular, contributions to one target (e.g. combating crime) should not be a priori detrimental to the implementation of other targets (e.g. promotion of the rule of law or accountable and transparent institutions).

Transparency: Activities should be reported with sufficiently detailed descriptions to allow scrutiny, while maintaining some degree of confidentiality in situations where personal safety is plausibly endangered.

Exclusion of lethal equipment: The provision of lethal equipment and support for or participation in kinetic activities are not eligible to TOSSD, with the exception of peacekeeping operations.

Compliance with international conventions and protocols: The presumption is that activities in the area of peace and security reported as TOSSD comply with international human rights law, refugee law, international humanitarian law and the Oslo guidelines.

Compliance with development effectiveness principles: As emphasised in the Preamble, the default assumption is that all support captured in TOSSD complies with development effectiveness principles, in particular ownership of sustainable development priorities by recipient countries and focus on results. It is also assumed that the activity is consistent with anti-corruption conventions and practices.

The eligibility of peace and security activities in TOSSD has no impact on the rules governing eligibility to be reported as ODA.

Review mechanism: The TOSSD governance body will undertake regular reviews of peace and security activities reported in TOSSD in order to examine their alignment with the 2030 Agenda and propose revisions of the eligibility criteria if needed.

The interviews with officials from the Ministry of Foreign Affairs confirmed the relevance of the general principles and safeguards governing the eligibility of peace and security activities in TOSSD (see the box above). Staff interviewed thought the principles provide a clear benchmark and particular emphasis

\footnotetext{
${ }^{57}$ https://kemlu.go.id/portal/en/read/91/halaman list lainnya/indonesia-and-the-united-nations-peacekeepingmission

${ }^{58}$ https://www.youtube.com/watch?v=kHm-U7 hQVc
} 
was placed on the host country ownership and the need to respect and protect human rights ${ }^{59}$ and the rule of law.

\section{Peace operations}

TOSSD UN peacekeeping operations and other peacekeeping operations mandated by a UNSC resolution are eligible for TOSSD. These operations follow three basic principles:

- Consent of the parties: United Nations peacekeeping operations are deployed with the consent of the main parties to the conflict. This requires a commitment by the parties to a political process and their acceptance of a peacekeeping operation mandated to support that process.

- Impartiality: United Nations peacekeeping operations must implement their mandate without favour or prejudice to any party. Impartiality is crucial to maintaining the consent and co-operation of the main parties. Impartiality may be seen as playing a fundamental function in drawing the limits to the use of force and its purpose. Impartiality does not prohibit peacekeepers from using military force, but links and limits the use of force to a political process and the search for a political solution. The logic differs for counterterrorism which requires the identification of an enemy.

- Non-use of force except in self-defence and defence of the mandate: A United Nations peacekeeping operation only uses force as a measure of last resort, when other methods of persuasion have been exhausted, and an operation must always exercise restraint when doing so. The ultimate aim of the use of force is to influence and deter spoilers working against the peace process or seeking to harm civilians; and not to seek their military defeat.

For other peacekeeping operations mandated by non-military regional organisations, a justification should be provided that the mandate is focused on the protection of civilians, not on defeating an enemy. Operations should support the creation of conditions for lasting peace, and not have an explicitly belligerent role and approach. They should comply with the three basic principles of UN operations listed above.

Expenditures related to peacekeeping operations should be recorded in Pillar II, to reflect that the operations, even if located in specific countries, seek to address a threat to "international" peace and security, and hence a global challenge.is presumed when some TOSSD-eligible countries are members of the organisation.

Indonesia fully supported the inclusion of UNSC-mandated peace operations in TOSSD as contributions to the SDGs. Regarding peace operations mandated by non-UN organisations, their inclusion should be assessed case by case, with particular attention being paid to the consent of the host country and the mandate of the mission which should not be based on a belligerent approach. Indonesia also supported the inclusion of peace operations in TOSSD Pillar II as regional and global expenditures for international peace and security, which is an international public good. This would be consistent with the fact that the UN Security Council only discusses issues that constitute a threat to international peace and security and not purely domestic issues. Indonesia is very cautious that UNSC decisions, as well as peace operations mandated by other organisation, do not intrude in domestic affairs.

In addition, Indonesia emphasises the following key points for effective international peace operations ${ }^{60}$ :

i. The need for context-specific peacekeeping approaches.

\footnotetext{
${ }^{59}$ For human rights, see https://peacekeeping.un.org/sites/default/files/indonesia-statement-ministerial-2019.pdf

60 http://embajadaindonesia.es/indonesian-foreign-minister-leads-un-security-council-session-an-indonesian-majorinspires/
} 
ii. The ability to interact with local communities (community engagement) is essential. The peace mission forces should not only rely on technical abilities and fighting tactics, but must also be able to interact with communities in conflict areas, so that they can carry out the UN mandate as expected ${ }^{61}$.

iii. The importance of promoting the role of women.

iv. The need of strengthening the trainings through global partnerships. ${ }^{62}$

In addition to paying its share of the UN peacekeeping budget, Indonesia contributes troops (expected to grow from approximately 3000 to 7000 in future years). For Indonesia, the participation in international peacekeeping is an important and concrete indicator of a country's contribution to the maintenance of international peace and security. ${ }^{63}$ In order to adequately reflect the full extent of the costs associated with international peacekeeping, Indonesia recommends looking beyond the traditional view of only looking at the cost of deployment of police and troop contingents:

- The reimbursement schemes voted by the UNSC do not always fully cover the deployment costs incurred by police and troop contributing countries. Although it might be challenging in practice, TOSSD could explore options for reflecting the full cost of deployment.

- The UN reimbursements do not cover the pre-deployment costs related to the recruitment, training and preparation of the police and troops, which are absolutely necessary for a successful peace operation. The peace mission forces do not only need to have technical and combat abilities, but must also be able to behave as peacekeepers. This includes the ability to interact and engage with communities in conflict areas. ${ }^{64}$ In Indonesia, this pre-deployment preparation is carried out in the Peace Forces Training Centre and the related costs are financed from the budget of the Ministry of Defence. Indonesia also offers that the Peace Forces Training Centre located in Indonesia becomes a training centre for world peace forces. ${ }^{65}$

\section{Disarmament}

Disarmament activities are generally eligible to TOSSD, including activities conducted in the context of Disarmament, Demobilisation and Rehabilitation (DDR), Small Arms and Light Weapons (SALW) control, removal of land mines and explosive remnants of war and reduction and elimination of biological, chemical and nuclear weapons.

Indonesia supported a broad coverage of disarmament activities, including those related to the reduction and elimination of biological, chemical and nuclear weapons. Indonesia is one of the 39 countries that have ratified the Treaty on the prohibition of nuclear weapons, a legally-binding United Nations instrument aimed at prohibiting nuclear weapons, leading towards their total elimination ${ }^{66}$.

\footnotetext{
${ }^{61}$ https://peacekeeping.un.org/sites/default/files/indonesia-statement-ministerial-2019.pdf

62 http://embajadaindonesia.es/indonesian-foreign-minister-leads-un-security-council-session-an-indonesian-majorinspires/

63 https://kemlu.go.id/portal/en/read/91/halaman list lainnya/indonesia-and-the-united-nations-peacekeepingmission

${ }^{64}$ https://peacekeeping.un.org/sites/default/files/indonesia-statement-ministerial-2019.pdf

65 http://embajadaindonesia.es/indonesian-foreign-minister-leads-un-security-council-session-an-indonesian-majorinspires/

66 The Treaty on the Prohibition of Nuclear Weapons was signed by 80 countries and ratified by 34 States. In order to enter into effect, the Treaty needs to be ratified by 50 countries.
} 
Indonesia is also party to the International Biological Weapons Convention and is currently preparing a draft law on biological security. ${ }^{67}$ However, Indonesia stresses also that global disarmament efforts should not limit the access of countries to technologies for the peaceful uses of nuclear energy and biological agents. $^{68}$

\section{Law enforcement activities, including the fight against organised crime and terrorism}

To be eligible for inclusion in TOSSD, the support to law enforcement agencies to combat organised crime should be guided by the United Nations Convention against Transnational Organised Crime and the three supplementary Protocols on Trafficking in Persons, Smuggling of Migrants and Trafficking of Firearms.

Similarly, to be eligible for inclusion in TOSSD, the support to law enforcement agencies to prevent and combat terrorism should be guided by the United Nations Global Counter-Terrorism Strategy.

Indonesia confirmed the validity of the United Nations Convention against Transnational Organised Crime (UNTOC) and the United Nations Global Counter-Terrorism Strategy (GCTS) for guiding the TOSSD eligibility of activities aimed at combating organised crime and terrorism. Both these frameworks are used as a reference in Indonesia. The Government of Indonesia also considers that international police co-operation contributes to SDG 16, as it is key for ensuring effective law enforcement, in particular when related to transnational crime. In addition, Indonesia stressed the critical importance of:

- Rule of law-based approaches.

- Comprehensive approaches including soft measures and community approaches (e.g. building the resilience of the youth).

Indonesia also recognised the challenges that can be posed by the lack of an international definition of terrorism.

\section{Engagement with the military}

Eligible activities include: i) capacity building of partner countries' armed forces to make them credible, accountable and managed under democratic control in an ethically-balanced and self-sustainable way; ii) training of partner countries' military in delivering any activity that has a development impact, for the benefit of civilians; and iii) delivery of humanitarian assistance by the military.

Any other type of engagement with the military is excluded from TOSSD.

For Indonesia, issues related to national defence are not covered by the SDGs and should therefore not be included in TOSSD. However, activities related to Security Sector Reform (SSR), which support the building of "effective, accountable and inclusive institutions" contribute to the achievement of SDG 16 (Peace, Justice and Strong Institutions) and should be covered. In addition, the delivery of humanitarian assistance by military personnel should be covered in TOSSD. Indonesia has already supported, in the past, other countries in Security Sector Reform or through the delivery of humanitarian assistance by military personnel.

67 https://kemlu.go.id/portal/en/read/90/halaman list lainnya/disarmament-and-non-proliferation-of-weapons-ofmass-destruction

68 https://kemlu.go.id/portal/en/read/90/halaman list lainnya/disarmament-and-non-proliferation-of-weapons-ofmass-destruction 
International tribunals

Activities of international tribunals and related organs are eligible to TOSSD. These activities should be reported in Pillar II, even when related to a tribunal/organ prosecuting crimes perpetrated in specific countries.

Indonesia commented that international tribunals should be included on a case-by-case basis. The key criteria should be the consent of the people concerned and the primary objective of reconciliation. For Indonesia, the most effective strategies to achieve national reconciliation are based on nationally-driven justice processes and as such it is important to build the capacity of local tribunals. 


\section{Reporting format and detailed instructions}

This Chapter provides the perspective of Indonesian stakeholders on specific items contained in the reporting format of the TOSSD Reporting Instructions, notably for those items that were considered as particularly important in the context of Indonesia.

\subsection{Reporting cycle (\$73-74 of the Reporting Instructions)}

74. Data on TOSSD provided in any given year $Y$ should be submitted to the custodian agency as early as possible in $Y+1$, and in any case not later than 30 July for Pillar I and 1 October for Pillar II (see timeline in Figure 5).

To inform Indonesia's planning, it would be preferable if TOSSD data were published in October or November of $Y+1$. Indonesia also insisted that data from providers should be validated and complemented by data from the recipient countries, on a voluntary basis, and in line with their capacities. Furthermore, Indonesia insisted that provider countries and institutions should build developing countries' capacities to set up their own systems to report and analyse TOSSD data.

\subsection{Reporting instructions item by item (\$77-89 of the Reporting Instructions)}

\section{Item 6. TOSSD recipient ( $\$ 32$ and 83 of the reporting instructions)}

32. TOSSD recipients are identified in the list of eligible recipient countries and territories for pillar I and, for pillar II, include international institutions. Some countries and international institutions have a dual role and are both TOSSD recipients and providers.

50. To count as TOSSD, an activity should involve a cross-border resource flow to a country on the List of TOSSD recipient countries. For any reporting year, this List includes:

i. All countries and territories that are present on the "DAC List of ODA recipients"

ii. Other countries and territories that have activated the TOSSD opt-in procedure.

Indonesia supported the recognition of the dual role of provider and recipient of certain countries and advocated for a list of recipients that is as wide as possible, so that TOSSD can be implemented for as many countries as possible.

\section{Item 10. SDG Focus ( $\$ 37$ and 87 of the Reporting Instructions)}

37. "The SDG focus specifies the goals and targets that the activity directly and significantly contributes to. It does not capture the indirect impact that the activity might have on various goals and targets over a longer timeframe." 
87. Multiple codes identifying the target(s) in the UN list of SDG targets (e.g. 2.1, 3.3). Report the values separated by a ";". In case no direct link can be found to an SDG Target, report the goal as "x.0", for example "2.0" for Goal 2. Only report the targets that the activity directly and significantly contributes to. It is expected that, for most projects, the number of SDG targets should not exceed ten.

Indonesia has carried out an analysis of the interlinkages of the various goals and targets and referred to work done by the "Institute for Global Environmental Strategies" (IGES) ${ }^{69}$ on this matter (IGES, 2017[34]).

\section{Item 11. Sector (\$88 of the Reporting Instructions)}

88. Multiple codes identifying the sector(s) that the resource is intended to foster. Reporting is based on either the OECD Creditor Reporting System purpose codes classification or the latest International Standard Industrial Classification (maintained by the UN Statistics Division). Data reported in ISIC will be converted to the OECD CRS classification by the custodian agency using conversion tables.

According to the interviews carried out, there is no standard governmental sector classification adopted for development co-operation. The Bank of Indonesia uses the International Standard Industrial Classification (ISIC) classification.

\section{Item 16. Financing arrangement (\$110 of the reporting instructions) \\ 110. Various forms of financing arrangements of particular interest in the context of TOSSD are:}

BLENDED FINANCE - the strategic use of development finance for the mobilisation of additional finance towards sustainable development.

ISLAMIC FINANCE - sharia-compliant finance (the Islamic finance instruments are included in the financial instruments classification in the relevant categories).

CO-FINANCING ARRANGEMENTS INVOLVING RECIPIENT COUNTERPART FUNDS - the cofinancing by the recipient country public institutions.

OFFICIALLY SUPPORTED EXPORT CREDITS - credits extended by government-owned or controlled specialised export-financing agencies or institutions (ECAs) for commercial purposes to finance a specific purchase of goods or services from within the creditor country. They include both official direct export credits (i.e. loans extended by ECAs to facilitate exports to developing countries) and officiallyguaranteed/insured export credits (i.e. loans extended by the private sector, but guaranteed/insured by ECAs to finance an export transaction).

Indonesia agreed with the definition of blended finance that does not require any pre-defined concessionality level for blending.

Regarding Islamic Finance, Indonesia welcomed the inclusion of this financing arrangement, particularly as it is very much used by the Government to finance sustainable development. Islamic finance is also widely used for local development projects. It constitutes a valuable financing source, especially for countries with large Muslim populations, with the potential to unlock untapped local financing resources from Muslim communities.

Indonesia also proposed two additions in the financing arrangement section:

- "Green financing", which would be defined as "overall support of the financial service industry for sustainable growth that results from [the] harmony between economic, social and environmental issues" (Indonesian Ministry of Finance).

${ }^{69}$ https://www.iges.or.jp/en 
- "Impact investment", which would be defined as "investments made into companies, organisations, and funds with the intention to generate social and environmental impact alongside a financial return (in line with the definition of the "Global Impact Investing Network" ${ }^{70}$ ).

\section{Item 17. Framework of collaboration (§ 111 to 113 of the Reporting Instructions)}

Other frameworks of collaboration will be tracked under this item and include:

SOUTH-SOUTH CO-OPERATION - a broad framework of collaboration among countries of the South in the political, economic, social, cultural, environmental and technical domains. Involving two or more developing countries, it can take place on a bilateral, regional, intraregional or interregional basis. Developing countries share knowledge, skills, expertise and resources to meet their development goals through concerted efforts.

TRIANGULAR CO-OPERATION - involves a partnership among at least three partners:

- The beneficiary partner that requests support to tackle a specific development challenge.

- The pivotal partner that has proven experience in tackling the issue, and shares its resources, knowledge and expertise to help others do the same.

- The facilitating partner that helps connect the partners, supporting the collaboration financially and technically.

Indonesia supported the typology of "frameworks of collaboration" covering South-South Co-operation and Triangular Co-operation. The country considered it as sufficient and in line with SDGs indicator 17.9.1. ("Dollar value of financial and technical assistance - including through North-South, South-South and triangular cooperation"). This typology was also welcomed as it was considered as applicable to the Indonesian context.

Indonesia also agreed with the proposed SSC definition and suggested modifications to the definition of Triangular Co-operation (see section 6. above).

70 https://thegiin.org/ 


\section{Part IV. Financing for \\ sustainable development provided by Indonesia and capacity to report on TOSSD}

This part provides a review of public finance provided by Indonesia in support of the sustainable development of other countries (TOSSD Pillar I) and in support of regional and global sustainable development (TOSSD Pillar II). It also assesses the usefulness for, and the capacity of, the Government of Indonesia to report on these expenditures. Chapter 9 focuses on TOSSD Pillar I and Chapter 10 on TOSSD Pillar II. 


\section{Official support provided by Indonesia to other countries and capacity to report on Pillar I}

\subsection{Overview of Indonesia's development co-operation and institutional architecture for development finance data}

\subsubsection{Overview of historical and political foundations for development co- operation provided by Indonesia}

The foundations of Indonesia's development co-operation take roots in the Africa-Asia conference of Bandung in April $1955^{71}$. Since then, development co-operation has been part and parcel of the Indonesian Government's external action. Development co-operation is seen both as an activity of strategic diplomacy and as a necessary act of solidarity towards developing countries. Indonesia's commitment to development co-operation is reflected in its constitution, which highlights the need to "participate toward the establishment of a world order based on freedom, perpetual peace and social justice". Indonesia is committed to assist other developing countries in implementing the SDGs and to ensure that no one is left behind (Gol, 2019, p. 186 $\left.6_{[14]}\right)$.

The commitment of Indonesia to broader international co-operation is reflected in the long-term national plan 2005-25 ( (Gol, 2007[35]). Co-operation with other countries and organisations is one of the eight "national development missions" of Indonesia. Operationally, the plan also sets out as one of its targets to enhance the role of Indonesia in the international community, including through "the increased leadership and contribution of Indonesia in various international co-operation in the context of realizing a world order that is more just and peaceful". The vision to enhance the role of Indonesia in support of development cooperation is also reflected in the medium-term development plans, including the one for 2015-19 (Gol, $\left.2015_{[36]}\right)$. In this plan, the objective of Indonesia is not only to bridge the interests among countries in establishing a more just, equal, and mutually beneficial world order, but also as an investment to achieve the goals of the national Indonesian agenda, without losing the essence of international solidarity.

\subsubsection{Overview of the legal framework}

Indonesia is gradually strengthening its legal framework for implementing South-South and Triangular Co-operation (SSTC). Beyond the national constitution and the national development plans, which provide the overall political guidance for delivering international co-operation, the Indonesian legal framework is still largely in development. Over the years, the country has issued government regulations, national plans and presidential instructions to guide Indonesia's development co-operation:

\footnotetext{
${ }^{71}$ See more about the conference at https://kemlu.go.id/portal/en/read/48/view/museum-konferensi-asia-afrika
} 
- The Law No. 25/2004 on the National Planning System, related to the planning process and the formulation of policies, including of international development co-operation activities.

- The Government Regulation No. 39/2006 on Monitoring and Evaluation of Development Performance, which sets out the rules in terms of Controlling and Evaluating the Implementation of Development Plans (including for international development cooperation activities)

- The Government Regulation No. 100/2011 on the Procedures for Foreign Loans Procurement and Grants receipt.

- The Government Regulation No 17/2017 on the synchronisation of planning and budgeting systems, which regulates the yearly planning and budgeting mechanisms.

In 2019, Indonesia notably issued a government regulation No.57/2019 as a change to the previous Regulation No.48/2018 on "Providing grants to Foreign Governments and Institutions" (Gol, 2018[37]). The regulation provides a legal foundation for Indonesia to actively support international development and is considered an important milestone for the country as it features Indonesia as a Southern provider. The regulation also mandates the establishment of an institution to manage funds for international development co-operation. The regulation is currently being further complemented with additional technical guidance in key areas (e.g. grant policy, procedures and monitoring and evaluation).

At the institutional level, Indonesia set up in 2010 a National Coordination Team on South-South and triangular co-operation comprised of the Ministry of Foreign Affairs, the Ministry of National Development Planning/Bappenas, the Ministry of Finance and the Ministry of State Secretariat. In 2016, the Government decided to transition the leadership of the National Coordination Team on South-South and triangular co-operation from the Ministry of National Development Planning to the Ministry of Foreign Affairs, effective as of 2017. The transition aimed to optimise the use of SSTC as a tool for Indonesian diplomacy. The division of labour between the various entities is now as follows:

- The Ministry of Foreign Affairs is the overall coordinator of the SSTC programme of Indonesia and the front liner in terms of diplomacy.

- The Ministry of National Development Planning/Bappenas is in charge of formulating the overall strategy and development plans, working in particular with line ministries on planning and implementing their SSTC interventions.

- The Ministry of Finance provides overall budget allocations for SSTC and, together with the Ministry of National Development Planning/Bappenas, decides on the specific allocations for Indonesia's assistance.

- The Ministry of State Secretariat supports the administrative process, provides the links to the President's Office and ensures consistency with Indonesia's government policies.

On 18 October 2019, Indonesia launched the Indonesian Agency for International Development, Indonesian-AID, under the guidance of a Steering Committee, which consists of the Minister of Foreign Affairs, the Minister of Finance, the Minister of National Development Planning/Head of National Development Planning Agency/Bappenas and the Minister of State Secretariat. The objectives of setting up the agency was to improve the efficiency, effectiveness, and transparency in the implementation of Indonesia's international development co-operation, particularly on the awarding of grants. The Agency is financed using a "Special Fund" of about 2 trillion rupiah (USD 135 million) to provide development aid or disaster relief to other countries. The Fund is expected to increase every year. The Ministry of National Development Planning/Bappenas, the Ministry of Finance and the Ministry of National Development Planning/Bappenas will be responsible for managing the Fund at the state budget level. On a daily basis, a special "Fund management unit" or special "public service agency" (Badan Layanan Umum/BLU) will manage the fund based at the Ministry of Finance.

Finally, it is worth noting that there is currently no specific strategy for allocating funds across various multilateral organisations. 


\subsubsection{Current content, focus and institutional set-up of Indonesia's development co-operation}

\section{Bilateral co-operation}

Indonesia's development co-operation is provided, among other modalities, through South-South and triangular co-operation (SSTC) and information is regularly collected on these flows. Indonesia has intensified its SSTC activities in the last five years. The number of these activities increased from 24 in 2014 to 59 in 2018 (Gol, 2019 [14]) reaching 451 beneficiaries in 2014 and more than 1000 in 2017 (National Coordination team of SSTC, 2015[38] (National Coordination Team of SSC, 2018[32]). The annual budget for SSTC is currently about USD 10 million per year (interviews with the Ministry of Finance indicated that, on average, about $80 \%$ of this budget is disbursed). This budget is used to finance technical co-operation, including costs related to experts, and does not include grants provided in cash. Funding for Indonesia's SSTC comes mainly from the State budget and is implemented through Indonesia's Ministries and State Agencies. Other sources of financing can include international development partners through triangular co-operation (see Box 2), cost sharing with the beneficiary countries, private sector funds and trust funds [e.g. World Bank South-South Facility and Perez Guerrero Trust Fund (National Coordination Team of SSTC, 2016[39])]. In order to increase the SSTC budget, the Government aims to broaden the funding sources beyond the State Budget, for example through the participation of the private sector. (National Coordination Team of SSC, 2017[40]). As shown in its SSTC reports, Indonesia avoids monetising its cooperation to keep a focus on the results of the activity rather than the amounts invested.

\section{Box 2. Indonesia uses triangular co-operation to expand its development co-operation activities}

As is the case for most providers, Indonesia's international development co-operation activities are mainly funded by the state budget. Since these financial resources are limited, the country co-operates with its "traditional" development partners (e.g. Germany, JICA and USA) through triangular cooperation mechanisms. $41 \%$ of Indonesia's development co-operation is carried out using triangular cooperation as a framework of collaboration in 2017 (National Coordination Team of SSC, 2018[32]). For example, the Ministry of National Development Planning/Bappenas has engaged development partners in several triangular co-operation activities such as:

- The sharing of experience on planning and budgeting between the Government of Indonesia and the Government of the Republic of the Union of Myanmar (2015)

- The Reverse linkage project on the strengthening of artificial insemination of livestock with Kyrgyzstan $(2015-2017)$

- The Capacity development for Indonesia Village Development Innovation Programme (2016 2020)

- A "Workshop on Teaching Factory" - Technical Vocational Education and Training (TVET) between Indonesia, Myanmar and Germany (2017)

- The Capacity Development Project on Road Maintenance of Timor-Leste. The project, also referred to as "the Yen Loan Project", was implemented by the Ministry of Public Works, Transportation and Communications of Timor-Leste in co-operation with the Ministry of Public Works and Housing of the Republic of Indonesia, and the Japan International Cooperation Agency as development partners.

Source: Interviews with Ministry of National Development Planning/Bappenas and (National Coordination Team of SSC, 2018[37]) 
SSTC activities span over a large number of recipient countries and are carried out based on demand from these countries. Since 2014, Indonesia provided SSTC to: Afghanistan, Bangladesh, Ethiopia, Fiji, Ghana, Nepal, Nigeria, Pakistan, Papua New Guinea, the Philippines, the Solomon Islands, and Timor Leste. For triangular co-operation activities, the main partners were Germany, Japan, the UK and the US. The activities took the form of trainings, workshops and seminars, dispatch of experts, scholarshipsinternships, and other knowledge sharing events. Trainings and expert dispatches were the two types of programmes most used (Gol, 2019 [14] $)$.

To strengthen its development co-operation, Indonesia has carried out a mapping of 22 "Resource Centres", with the support of the Islamic Development Bank. ${ }^{72}$ These Resource Centres are government and private institutions in Indonesia with recognized expertise and knowledge in 12 economic sectors, namely agriculture, maritime and fisheries, health and population, engineering, vocational training, planning and budgeting, microfinance, transportation, technology, industry, trade and disaster mitigation. The mapping provides a comprehensive presentation of Indonesia's areas of expertise and allows developing countries to better target their requests of support to Indonesia based on these areas. In addition, Indonesia is promoting its SSTC programme through various roadshows to universities, in international fora (e.g. BAPA+40) and through exhibitions and workshops. ${ }^{73}$

In addition to the data currently collected on a regular basis, Indonesia could compile information on the following flows to provide a more comprehensive view of its development co-operation activities (see also section 9.2.1 below), including:

- Cash grants provided by the Ministry of Finance.

- In-kind commodity and humanitarian aid (e.g. food aid). These data could be collected from BNPB (Badan Nasional Penanggulangan Bencana - the Disaster Prevention Agency) and from the Ministry of Finance.

- In-kind technical co-operation (i.e. government civil servants intervening as experts to support other countries). These data could be collected directly from the various line ministries or from the Ministry of State Secretariat. ${ }^{74}$ Interviews during the in-country mission showed that in-kind technical co-operation - i.e. the use of civil servants to deliver development co-operation activities - is not yet valorised, even if a methodology is being considered at the MOF for this purpose (see Section 6.4).

- Co-operation related to Peace and Security (e.g. Afghan intra-dialogue - data could be collected from the MOFA and the Ministry of Defence).

- Co-operation using Islamic Finance (e.g. Zakat funds through BAZNAS).

- Possibly some export credits in support of sustainable development (from the EXIM Bank of Indonesia).

The creation of the Indonesian Agency for International Development, Indonesian-AID, appears as a key opportunity to carry out a review of Indonesia's development co-operation activities which could then inform a full-fledged strategy to support partner countries using the entirety of Indonesia's instruments and agencies. The stock-take would include the entirety of Indonesia's development co-operation efforts towards sustainable development, using all of the available instruments and modes of co-operation at its disposal, under the leadership or coordination of the new single Agency. Collecting information on all the flows mentioned above - which are part of the TOSSD framework - would

\footnotetext{
72 https://bit.ly/MIRCs

${ }^{73}$ For more information see Box n41 in (Gol, 2019, p. 188 [14])

74 The Ministry of State Secretariat has a record of all civil servants dispatched abroad, but there is no possibility at this stage to disaggregate which ones are part of an SSTC activity.
} 
allow Indonesia to have a much more comprehensive picture of its activities supporting other countries in the achievement of the SDGs.

As indicated in section 6.5, it is also worth noting that, as part of its development co-operation, Indonesia does not currently use loans or guarantees and debt relief. The mission could not find evidence either of the use of other types of instruments notably equities or mezzanine finance instruments. Therefore, Indonesia has no data to report on private finance mobilised through official development interventions in support of the sustainable development of other countries.

\section{Multilateral co-operation}

Indonesia's estimated development co-operation channelled through multilateral organisations amounted to USD 129 million in 2016, up from USD 14.2 million in 2015. This is due to a contribution to the newly created Asian Infrastructure Investment Bank of USD 134 million, of which USD 114 million is considered development-oriented. According to OECD estimates, in 2016 Indonesia channelled most of its multilateral development co-operation through the Asian Infrastructure Investment Bank (89\%) (OECD, 2018[41]).

The mission team could not find evidence of a "multilateral strategy" which would clarify Indonesia's priorities for allocating funds to multilateral organisations.

\subsection{A strong capacity to collect data on TOSSD Pillar I, but some scope for increased data coverage}

\subsubsection{Focus and scope of the capacity assessment}

The assessment included in this chapter focuses on Indonesia as a provider of development cooperation. In the course of the preparations of the pilot study in Indonesia, the Government insisted that the mission team should carry out the assessment focusing on the Government's capacity to collect, compile and disseminate development finance data as a provider of development co-operation rather than as a recipient. This is a different approach than the one used in previous TOSSD country pilots ${ }^{75}$, but was necessary to maximise the relevance of this specific TOSSD pilot study for the Government of Indonesia, a country that is gradually becoming a provider of development co-operation. ${ }^{76}$

The assessment covers the capacity to collect and report on South-South and triangular cooperation information. As highlighted in section 9.1.3, Indonesia's development co-operation is mostly carried out through South-South and triangular co-operation. As such, there is an existing process for collecting, compiling and disseminating SSTC data, which leads to the production of a South-South and Triangular co-operation report. As highlighted above (see "bilateral co-operation" in section 9.1.3), other types of flows do not benefit from a similar data collection process and cannot therefore be analysed yet. ${ }^{77}$ As a consequence, the present chapter mostly focuses on the data collection process that leads to the production of the SSTC report (these flows will fall under the Pillar $\mathrm{I}^{78}$ of TOSSD). In order to also support

75 http://www.oecd.org/dac/financing-sustainable-development/development-finance-standards/tossd-country-pilotstudies.htm

76 See also Chapter 3. .

77 As highlighted in chapter 4.2.3.Part III, there will be a need to develop processes to collect, analyse and disseminate information on flows that are not part of the SSTC programme and also on TOSSD Pillar II activities.

78 For general information on the Pillars I and II of TOSSD see (OECD, 2019 $[47]$ ) and for a more detailed explanation on what constitutes Pillar I and Pillar II, see (International TOSSD Task Force, 2019[2]) 
the future collection of TOSSD data beyond SSTC, the authors have included in this chapter some elements of the Government's capacity to collect TOSSD Pillar II-related information.

It is also worth noting that the creation of the Indonesian Agency for International Development, Indonesian-AID, (see section 9.1.2) may trigger changes in various data collection and dissemination processes.

\subsubsection{A well-structured process of data collection on SSTC activities, but a need to ensure greater comprehensiveness of the data collected, even on SSTC}

\section{Overview of the data collection process}

The National Coordination Team (NCT) on South-South and triangular co-operation is overseeing the data collection process and production of Indonesia's annual report on SSTC. For data related to a given year "Y", the typical timetable is as follows:

- January - 15 July $Y+1$ : Data are collected through a specific data survey. A letter requesting data on SSTC activities is sent to the relevant institutions, in particular line ministries.

- August-September $Y+1$ : The NCT compiles the information and finalises the dataset, requesting feedback from line ministries as appropriate.

- October-December Y+1: The NCT drafts the report.

- Before the end of the year $Y+1$ : The State Secretariat compiles the full report and organises the launch with the rest of the NCT.

\section{Main challenges}

The main challenge that the Government faces in terms of data collection relates to the comprehensiveness of the reporting on SSTC activities. The NCT has difficulties in ensuring that the data in the SSTC report comprehensively represent the number of SSTC activities carried out. This is due to several factors.

- At the planning stage, Ministries have the opportunity to tag their activities as SSTC in the National Budget. However, not all of them do so since there is little incentive for them to report their activities. The absence of a legal framework or obligation to report prevents the NCT from having from the outset a full picture of the potential SSTC activities to be carried out in the upcoming fiscal year.

- At the implementation stage, there is no possibility for the NCT to collect data on the SSTC activities actually implemented by line ministries. This is because Indonesian line ministries can enter into agreements directly with line ministries of other countries without referring to any of the ministries that are members of the NCT. At the time of the in-country mission, there was no incentive nor legal obligation ${ }^{79}$ for line ministries to inform the NCT when entering into agreements with other countries for SSTC activities. This is of particular concern to the NCT because most of the SSTC activities are indeed carried out by line ministries. ${ }^{80}$ With the new Indonesian Agency for International Development, Indonesian-AID, up and running, it is anticipated that the request of

\footnotetext{
${ }^{79}$ At the time of the in-country mission (August 2019), a regulation was under preparation to oblige line ministries to report their SSTC activities to the NCT.

80 It is worth noting that central ministries try to collect data at the planning and implementation stages. For example, data are collected by Bappenas on SSTC annually at the time of the preparation of the budget since line ministries need to discuss the focus of their interventions with Bappenas. At the implementation stage, the MOF has access to actual disbursements on SSTC activities by department. Despite these data collection processes, for the reasons highlighted above, achieving full comprehensiveness remains a challenge at this stage.
} 
grants for projects with other countries will be made by line ministries to the new agency who will then be in a position to monitor in detail SSTC activities.

- Finally, at the time of the yearly data survey on SSTC, the NCT cannot ensure that line ministries actually provide a comprehensive list of their activities. This means that the number of activities reported for example in the 2017 SSTC report [59 activities in total involving more than 1000 participants (National Coordination Team of SSC, 2018[32])] is probably underestimated.

Another challenge highlighted by stakeholders is the absence of a definition of "development cooperation" in the context of Indonesia. It would be important that, as Indonesia grows as a provider of development co-operation, provides a clear vision of what it considers development co-operation, as well better defines its modes of intervention (e.g. is support for building a new mosque in another country considered as development co-operation?).

Indonesia has the capacity to report on TOSSD, but may require support to set up specific procedures for collecting TOSSD data. The mission also looked at the capacity of Indonesia to report on TOSSD. As it stands, Indonesia would be able report systematically on almost all of the fields in the TOSSD reporting form ${ }^{81}$ as a provider of development co-operation, except for the following ones: external link, SDG focus, sector against the ISIC or OECD-DAC classification ${ }^{82}$, TOSSD Pillar and salary costs. Stakeholders highlighted the necessity to build national capacity on how to analyse TOSSD data. The implementation of the TOSSD system will require dedicated capacity building activities, not only to set up the data collection system, but also to analyse the data (even though the overall analytical capacity at this stage is considered as strong - see next section). The Government of Indonesia stressed that if it provides data to TOSSD, it would also expect to receive capacity-building on how to analyse these data.

Recommendations to the Government on the data collection side include:

- Finalise the legal framework for collecting SSTC data, to ensure appropriate reporting by the line Ministries and other relevant institutions.

- Expand the scope of the data collected to flows beyond SSTC, as highlighted in section 9.2.1.

A recommendation to the International TOSSD Task Force ${ }^{83}$ and the future oversight mechanism of TOSSD would be to ensure that the TOSSD initiative includes a capacity-building programme to provide adequate capacities for countries to analyse a broader set of flows.

\subsubsection{Compilation, analysis and dissemination of SSTC information}

\section{A strong capacity to compile and analyse SSTC information with some room for expanding analysis to development results.}

Indonesia shows a strong capacity to compile information on its SSTC programme. Indonesia produced its very first national report on SSTC in 2015 (on 2014 activities) and has been consistently publishing such reports since then. ${ }^{84}$ The Government has also recently issued, as part of the Voluntary National Reviews of the SDGs at the United Nations, a comprehensive overview of its SSTC Programme (Gol, 2019, pp. 185-188[14]]).

\footnotetext{
81 See (International TOSSD Task Force, 2019, p. 20[2])

82 However, Indonesia has its own classification as shown by the sector analyses made in the various SSC reports.

83 For more information on the TOSSD Task Force, see: http://www.oecd.org/dac/financing-sustainabledevelopment/development-finance-standards/tossd-task-force.htm
}

${ }^{84}$ See (National Coordination team of SSTC, 2015[38]), (National Coordination Team of SSTC, 2016[39]), (National Coordination Team of SSC, 2017[40]) and (National Coordination Team of SSC, 2018[32]) 
The contents of the various reports produced since 2015 show the breadth and depth of Indonesia's capacity to analyse SSTC activities, with perhaps the need to improve the analysis of the impact of activities. The reports display SSTC data using a wide range of dimensions. These include, for example, the number of activities and beneficiaries, the breakdown of activities by region and country of intervention, the type of activities (e.g. training, dispatch of experts), a breakdown by broad programme areas (e.g. economic, social and governance), by sector or type of co-operation (e.g. SSC and triangular co-operation). Each report also present a number of case studies of SSTC in a various sectors and countries. Finally, a full list of activities is available in a table format at the end of each report. This table is organised along a number of dimensions, which have increased between 2014 and 2017 [e.g. the table of activities in (National Coordination Team of SSC, 2018[32]) now presents each activity along the following dimensions: short description of the activity, location, dates of the intervention, types of activities, implementation agencies, Development Partner(s), Southern Partner(s) and number of participants]. This provides a good basis for any user to get an overview of Indonesia's SSTC Programme.

There is a need to provide further information on results in the SSTC reports and in online communications. Indonesia carries out yearly thematic analysis of projects (e.g. in 2019, the Ministry of National Development Planning/Bappenas carried out a review of the vocational training projects). However, the SSTC reports and online communications do not provide much information about the impact of SSTC activities.

The team did not identify during the mission any specific needs for equipment, but the set-up of Indonesian-AID may require a dedicated capacity and training assessment. While overall capacities to deliver SSTC activities are considered by Indonesian stakeholders as strong, the set-up of the new Indonesian Agency for International Development, Indonesian-AID, may require a full-fledged capacity assessment beyond the present one to support the strengthening of Indonesia's development cooperation. At this stage, staff working on international development co-operation activities at the Ministry of National Development Planning/Bappenas have highlighted the following training needs: project management, cost and benefit analysis, monitoring and evaluation based on impact measurement, report writing, database development and management.

The promotion of Indonesia's SSTC programme has increased in recent years but further efforts are required to make Indonesia's co-operation better known, particularly internationally

As Indonesia becomes a provider of development co-operation, it has intensified the communication on its SSTC programme (National Coordination Team of SSC, 2018, p. 12[32]). The main targets of dissemination of international development co-operation activities are described by Indonesian stakeholders as very broad, from the line ministries to the general public, including the private sector, academia, NGOs, CSOs, media and beyond.

The various SSTC reports provide an overview of the dissemination activities carried out on SSTC, including:

- Formal launches of the various SSTC reports. For example, the 2017 SSTC Report was launched in October 2018 by the MOFA.

- An official website on SSTC at the Ministry of State Secretariat and communications on SSTC by other Ministries for example through newsletters. ${ }^{85}$. However, the 2017 report could not be

${ }^{85}$ https://www.bappenas.go.id/id/berita-dan-siaran-pers/kegiatan-utama/ 
found on this website, contrary to other editions of SSTC reports. The mission team could not easily find a web link for the 2017 report online86.

- Various roadshows and international events in universities and international fora (e.g. BAPA +40 , GSSD Expo and the Asia-Africa Forum Commemoration) and through exhibitions and workshops, as already highlighted in section 9.1.3. ${ }^{87}$ In 2015, Indonesia celebrated the 60 years of the Bandung Conference (National Coordination Team of SSTC, 2016[39]). The Conference even has its own Museum in Bandung. ${ }^{88}$ However, little information is available online in foreign languages on the "Indonesia's Resource Centres", one of the key tools for informing on Indonesia's development co-operation.

Recommendations to Indonesia to improve the dissemination of information on its SSTC programmes include:

- Participate in global efforts to report data for international statistics on development cooperation, for example by reporting on TOSSD starting 2020. Now that Indonesia is officially a provider of development co-operation with the creation of a dedicated Indonesian Agency for International Development, Indonesian-AID, it would be important that it contributes to international efforts to provide recipient countries and the international community with detailed information on its activities around the world. This will help recipient countries to get better access to the areas of expertise of Indonesia and help their own development planning. Indonesia could therefore start reporting on TOSSD in 2020.

- Set up a dedicated portal for the Indonesian Agency for International Development and publish activity-level data. This would enhance Indonesia's international profile, provide one point of entry for all stakeholders and give the opportunity to set up individual web pages for each project, which can then be linked in all communications to disseminate information. The full dataset of SSTC activities and beyond could be published on this portal in traditional (Excel) and machinereadable (e.g. Xml) format. Further information on the "Indonesia's Resource Centre" could also be included there in various languages if possible.

- Consider the possibility of expanding the scope of the SSTC report to provide a broader view on Indonesia's development co-operation beyond SSTC. As highlighted in the previous chapter, Indonesia's international development activities span much beyond SSTC. It may be worth looking at issuing a report that would look at development co-operation by Indonesia much beyond SSTC.

- Complement the next SSTC report and broader communication activities with:

1. A greater focus on results: the report should mention the SDG goals and targets for each activity. Indonesia could also reflect on how to better report on the results and impact it achieves both at the macro level and at the level of individual activities.

2. Additional information to provide greater insights to the public. This could include a web link on the various projects carried out by Indonesia and the sector against international classifications (e.g. the ISIC or CRS classifications).

\footnotetext{
${ }^{86}$ Search made online on 28 November 2019.

${ }^{87}$ For more information see Box n ${ }^{\circ} 41$ in (Gol, 2019, p. 188[14]) and (National Coordination Team of SSC, 2018, p. 12[32])

${ }^{88}$ See: http://asianafricanmuseum.org/en/museum-kaa/
} 


\section{Indonesia as a provider of finance for international public goods (TOSSD Pillar II)}

This chapter explores the potential of Indonesia as a provider of finance for international public goods/global challenges (TOSSD Pillar II). For provider countries reporting on TOSSD, Pillar II covers primarily public finance provided within their national borders ${ }^{89}$. The pilot focussed on the IPGs/global challenges that were identified in Annex E of the TOSSD Reporting Instructions and for which eligibility criteria exist. Biodiversity was also covered, given the importance of Indonesia in this field, although there were no specific TOSSD eligibility criteria at the time of the mission. More specifically, the following IPGs/global challenges were discussed with Indonesian stakeholders: Research \& Development (R\&D), environmental protection, and peace and security.

Section 10.1 provides an overview of public finance provided by the Government of Indonesia in support of these IPGs/ global challenges and discusses the usefulness for Indonesia of providing transparency on these expenditures through TOSSD. Section 10.2 assesses the capacity of the Government to measure and report these expenditures in TOSSD Pillar II.

\subsection{Public finance for international public goods in Indonesia}

\subsubsection{Research and development (R\&D)}

\section{General background on R\&D policies}

As part of the SDGs, countries have pledged to substantially increase, by 2030, public and private R\&D spending as well as the number of researchers. In TOSSD, under certain conditions specified in Annex E of the Reporting Instructions (International TOSSD Task Force, 2019 $\left.{ }_{[2]}\right)$ national R\&D spending can have the characteristics of an international public good and be reportable in TOSSD Pillar II. R\&D is one of the priorities identified by Indonesia in the context of both its national development plans and the roadmap for the achievement of the SDGs. In 2018, Indonesia issued the National Research Master Plan (RIRN) 2017$2045,{ }^{90}$ where eight R\&D priorities are identified: food, energy, health, transportation, engineering products, defence and security, maritime research and socio humanity. ${ }^{91}$ The Government also elaborates

\footnotetext{
89 In TOSSD, financing for sustainable development provided to other developing countries is captured in Pillar I. In addition, activities carried out at the regional or global level by multilateral institutions (e.g. norm-setting) are in principle reported by these institutions and not by provider countries.
}

90 Presidential Regulation 38/2018.

91 https://nerc.ukri.org/research/funded/programmes/hazards-seasia/funderpres-indonesia/ 
five-year strategies where national research priorities are defined, the latest one being the 2020-2024 National Research Priority (PRN).

According to the Roadmap of SDGs Indonesia (Ministry of National Development Planning/Bappenas, 2019 , p. $\left.88_{[1]}\right)$, Low R\&D budget and poor coordination in research activities are two main challenges of R\&D management in Indonesia. In order to address these challenges, the Government established in 2019 the National Research and Innovation Agency (BRIN) under the Ministry of Research and Technology (MoRT). The agency is mandated by the new Law on the National System of Science and Technology (Sisnas).$^{92} \mathrm{~A}$ presidential decree on the BRIN is currently being elaborated but the new research agency will notably coordinate, monitor and provide more transparency on research funding in Indonesia. The objective of the Government is to raise its R\&D budget from $0.2 \%$ of GDP in 2017 to $0.63 \%$ of GDP by 2030. The Government is also aiming to encourage more private sector funding for R\&D.

\section{Public finance for $R \& D$}

In 2018, Government Budget Appropriations or Outlays on Research \& Development (GBARD) in Indonesia amounted to USD 2 billion (IDR 29.8 trillion), representing $0.2 \%$ of its GDP, with USD 1.99 billion (IDR 28.9 trillion) from the central government budget and USD 61.5 million (IDR 890 billion) from the budgets of local governments. The MoRT is the first beneficiary of $R \& D$ funds from the central government.

In addition to government budget allocations, USD 150 million (IDR 2.16 trillion) was provided from the universities' own budgets, but these expenditures are not part of the GBARD since they are not part of the national budgetary process.

Allocations of $R \& D$ resources from the national budget are determined in the framework of the Budget Bill preparation on the basis of discussions between, on the one hand, line ministries that submit their proposals, ${ }^{93}$ and on the other hand, the Ministry of National Development Planning/Bappenas and the Ministry of Finance that are responsible for determining national priorities and allocating resources at the macroeconomic level. Each institution receiving government funds is then responsible for allocating these resources to specific R\&D projects.

\subsubsection{Environmental protection}

\section{General background on environmental policies}

Environmental protection is a key dimension of the SDGs. TOSSD Pillar II captures domestic financing for environmental protection to the extent that that it conveys transnational benefits [see Annex $E$ of the Reporting Instructions (International TOSSD Task Force, 2019[2])].

Combating climate change is a top priority for Indonesia as it is among the countries likely to be affected by the rise in sea levels ${ }^{94}$ and climate-induced disasters. ${ }^{95}$ The Government of Indonesia has made a number of commitments to step up its climate change mitigation and adaptation priorities. In 2011,

\footnotetext{
92 Law number 11/2019, article 48.

${ }^{93}$ Proposals are submitted at the level of sub-directorates.

94 Indonesia is an archipelagic country with extensive low-lying and small island areas.

95 Indonesia has already experienced extreme climate events such as floods and drought. According to Indonesia's 2016 Nationally Determined Contribution, "climate change is believed to increase the risk for hydro meteorological disasters, which make up to $80 \%$ of disaster occurrences in Indonesia".
} 
Indonesia adopted the National Action Plan for Reducing Greenhouse Gas Emissions (RAN GRK) ${ }^{96}$, which provides guidance to governmental institutions on how to implement activities aimed at reducing Greenhouse Gas (GHG) emissions. According to its 2016 Nationally Determined Contribution (NDC) ${ }^{97}$, Indonesia voluntarily committed to reduce $29 \%$ of its GHG emissions by 2030 , and up to $41 \%$ with international support through finance, technology transfer and development as well as capacity building. In 2017, the Ministry of National Development Planning/Bappenas launched the Low-Carbon Development Initiative to ensure that the Government's development plan is aligned with Indonesia's environmental objectives. The initiative introduces carbon emission reduction targets into development policy planning. Between 2010 and 2017, GHG Emissions in Indonesia decreased by 22.5\% compared to the national baseline reported to UNFCCC (Gol, 2019 $\left.{ }_{[14]}\right)$

Indonesia considers climate mitigation and adaptation as an integrated concept. In 2013, Indonesia adopted the National Action Plan on Climate Change Adaptation (RAN API) ${ }^{98}$ in order to harmonise and operationalise a number of other strategies and action plans that had been developed by various government institutions over the previous years ${ }^{99}$. The RAN API provides the action plan for adaptation in the short-term (2013-14), initiates the mainstreaming of the adaptation action plan into the National Medium Term Development Plan (RPJMN) of 2015-19, and establishes the long-term adaptation policy direction ${ }^{100}$.

Indonesia hosts the third largest rainforest area in the world, and is home to one of the richest marine and terrestrial biodiversity in the globe. In order to protect this biodiversity, the Government issued, in 2003, the Indonesian Biodiversity Strategy and Action Plan (IBSAP) 2003-2020, ${ }^{101}$ which is further sub-divided into several action plans, the latest one being the Indonesian Biodiversity Strategy and Action Plan (IBSAP) 2015-2020 (Gol, 2016[42]). The IBSAP provides a strategy for the protection and sustainable use of Indonesia's biodiversity in order to improve the economic and development opportunities for the Indonesian population. It addresses several SDGs, including Goals 12 (responsible consumption and production), 13 (climate action), 14 (life below water) and 15 (life on land). In order to address SDG target $14.1^{102}$ on marine protection, Indonesia committed to create 20 million hectares of Marine Protected Areas (MPAs), and, according to its 2019 Voluntary National Review (Gol, 2019 [14]), had already reached 19.3 million hectares in 2018. However, progress on SDG target $15.2^{103}$ on forest conservation is more difficult, as the proportion of forest covering the Indonesian land surface decreased from $52.22 \%$ in 2011 to $50.18 \%$ in 2017.

\footnotetext{
96 Presidential Decree No. 61/2011

97 The Paris Agreement requests each country to outline and communicate their post-2020 climate actions, known as their Nationally Determined Contributions (NDCs).

98 https://www.bappenas.go.id/files/2913/4985/2794/national-action-plan-for-climate-change-adaptation-ran-apisynthesis-report $20121226163242 \quad 0 . p d f$

99 These include the National Action Plan for Climate Change Mitigation and Adaptation (Ministry of the Environment, 2007), the Indonesia Climate Change Sectoral Road Map (Bappenas, 2010), the Indonesia Adaptation Strategy (Bappenas, 2011), the National Action Plan for Adaptation to Climate Change of Indonesia (National Council on Climate Change, 2011), and the sectoral adaptation plans compiled by line Ministries.
}

100 https://gc21.giz.de/ibt/var/app/wp342deP/1443/wp-content/uploads/filebase/programme-info/RANAPI Synthesis Report 2013.pdf

101 https://balaikliringkehati.menlhk.go.id/wp-content/uploads/IBSAP\%202003.pdf

102 By 2020 , conserve at least $10 \%$ of coastal and marine areas, consistent with national and international law and based on the best available scientific information

103 End deforestation and restore degraded forests. 


\section{Public finance for environmental protection}

Indonesia's investment needs in environmental protection are large. According to Indonesia's Third National Communication under the UNFCCC (Gol, 2017 $\left.{ }_{[43]}\right)$, the country's climate-related financing needs were estimated at USD 81 billion for the period 2015-2020, with USD 15 billion for climate change mitigation and USD 64 billion for climate change adaptation. ${ }^{104}$ In the Roadmap of SDGs Indonesia (Ministry of National Development Planning/Bappenas, 2019 $\left.{ }_{[1]}\right)$ the Government estimated that, for the period 2020-2030, the investment needs in environmental protection will reach an annual average of USD 2.5 billion (IDR 33.5 trillion) in a "business as usual" scenario, USD 2.9 billion (IDR 39.1 trillion) in a "moderate" policy intervention scenario and USD 3.3 billion (IDR 43.7 trillion) in a "high" policy intervention scenario (Ministry of National Development Planning/Bappenas, 2019 $\left.{ }_{[1]}\right)$. Environmental protection is defined as including forest and land rehabilitation, watershed management and protected forest control, waste management and hazardous and toxic waste management, and climate change mitigation.

In order to meet these investment needs, Indonesia allocates a significant and rising share of its national budget to climate-related expenditures. The State budget allocations for climate mitigation have increased from $0.34 \%$ of GDP in 2014 to $0.49 \%$ in 2018 , reaching a total of USD 5.13 billion (IDR 72.2 trillion). In 2018, most of the support was provided through the Ministry of Public Works and Housing (70\%) and the Ministry of Transportation (23\%). The State budget allocations for climate adaptation reached USD 2.6 billion (IDR 37.5 trillion) in 2018, representing $0.3 \%$ of the GDP. According to the Biodiversity Finance Initiative led by UNDP, total central government budget for biodiversity during the period 2006-2016 was estimated at around USD 3.5 billion. ${ }^{105}$ These amounts cover only resources from the State budget and do not include external financing for environmental protection.

In order to increase its investment capacity, Indonesia is also developing innovative financing schemes, in particular through the mobilisation of Islamic finance, which allows the Government to leverage untapped international and national financial resources. In 2017, the Government of Indonesia introduced a Green Bond and Green Sukuk Framework (the "Framework") in order to finance eligible green projects, i.e. "projects which promote the transition to low-emission economy and climate resilient growth, including climate mitigation, adaptation, and biodiversity (...)"106. The "Framework" is seen as aligned with Indonesia's aim to achieve the SDGs. In 2018, the Government completed the world's first sovereign issuance of green sukuks, raising a total amount of USD 1.25 billion, followed by the issuance of IDR 500 billion green bonds. Both issuances were oversubscribed ${ }^{107}$, signalling the high potential of green bonds/sukuks for sustainable development financing. In 2019, the Government completed a new issuance of green sukuks totalling USD 0.75 billion. According to officials interviewed, the Government issuance of green instruments has also triggered the issuance of green bonds by the private sector. In 2019, Indonesia issued the Allocation and Impact Report on the Green Sukuk Issuance ${ }^{108}$, which aims to provide transparency to investors and the public on the use of the proceeds of the issuance.

\footnotetext{
104 See page 194 https://unfccc.int/sites/default/files/resource/8360571 Indonesia-NC3-2Third\%20National\%20Communication\%20-\%20Indonesia\%20-\%20editorial\%20refinement\%2013022018.pdf 
Although this is currently out of the scope of TOSSD, the mission team investigated also the use of taxbased instruments in Indonesia. To date, Indonesia has not yet developed tax-based instruments to support its climate-related policies. However, the Government is trying to develop this type of climate finance. For example, the Government is currently working on a revision of the luxury tax scheme in order to promote the purchase and production of environmentally friendly cars. The tax will be based on the level of GHG emissions and fuel consumption.

In addition to the State budget, the national Zakat agency, BAZNAS, contributes to Government efforts towards climate financing through the mobilisation and distribution of Zakat funds. In 2018 and 2019, BAZNAS disbursed respectively IDR 94 billion (approximately USD 6.5 million) and IDR 104 billion (approximately USD 7.5 million) in support of climate mitigation projects. ${ }^{109}$

\subsubsection{Public resources for international peace and security}

Indonesia is an important voice on the international stage on peace and security issues. In 2018, the country has been elected as a non-permanent member of the United Nations Security Council (UNSC). Indonesia is committed to contribute to international peace and security based on "independence, eternal peace and social justice", as stipulated in its Constitution. ${ }^{110}$ Historically, this commitment was reflected in Indonesia's participation in, and contribution to, UN peace operations, which constitute today one of the top priorities of Indonesia's non-permanent membership in the UN Security Council 2019-20. ${ }^{111}$ Regarding the support to international peace and security, Indonesia highlighted the following points:

- Historically, Indonesia has been an important contributor of troops and police to UN peace operations. In 2012 Indonesia launched what was known as Vision 4,000 peacekeepers, with the objective to become a top-ten Troop and Police Contributing Country (TPCC) to UN Peacekeeping through the deployment of 4,000 peacekeepers. The goal top-ten TPCC was first achieved in February 2016, when Indonesia ranked ninth in the TPCC ranking with a total of 2,843 peacekeepers; Indonesia's highest achievement was in November 2018, when it ranked seventh with 3,545 peacekeepers. As of March 2020, Indonesia ranked eighth with a contribution of 2,852 peacekeepers in 9 UN Peace Operations.

- Indonesia puts great emphasis on the need of appropriate pre-deployment trainings and capacitybuilding for UN peacekeepers. ${ }^{112}$ The Government established in 2012 the Indonesian Peace and Security Centre, which also houses the Army's Peacekeeping Training Centre, and is currently also working on the establishment of a Police Peacekeeping Training Centre. The objective of Indonesia is to establish the Peacekeeping Training Centre as a world class and a front running peacekeeping training centre in the region. Indonesia is also planning to develop co-deployments of peacekeepers to UN Peace Operations with partner countries. Through the Triangular Partnership Project (TPP) ${ }^{113}$ the Indonesia Peacekeeping Training Centre, in collaboration with Japan and the United Nations, will provide in 2021 capacity-building and trainings to peacekeepers from 14 countries in the Asia-Pacific region.

- Indonesia emphasises the importance of regional approaches to peace and security.

\footnotetext{
${ }^{109}$ BAZNAS budgeted IDR 152 billion (approximately USD 10.5 million)

110 See paragraph IV of the Opening of the 1945 Constitution of the Republic of Indonesia.

111 See https://kemlu.go.id/portal/en/read/91/halaman list lainnya/indonesia-and-the-united-nations-peacekeepingmission

112 See https://kemlu.go.id/portal/en/read/91/halaman list lainnya/indonesia-and-the-united-nations-peacekeepingmission

${ }^{113}$ See https://operationalsupport.un.org/sites/defaultffiles/20191216 fact sheet - triangular partnership.pdf
} 
Indonesia is both a financial and troop contributor to UN peace operations. As discussed in section 7.2.3, Indonesia is of the view that financial contributions to international peace operations, which are aimed at only covering the deployment cost of police and troop contingents, provide a limited picture of the costs associated with these operations. The non-reimbursed costs incurred by troop and police contributing countries, such as Indonesia, during the operations should also be recognised and possibly reflected in TOSSD. In addition, as highlighted above, Indonesia allocates public resources to its Peacekeeping Training Centre. The Centre is supported financially by the Ministry of Defence.

In addition to financial, troops and police contributions to UN peace operations, the Ministry of Foreign Affairs carries out various political activities to support international co-operation in this area. For example, in 2018 Indonesia took part in the formulation of the UN Secretary General Action for Peacekeeping Initiative (A4P) $)^{114}$ and became one of its champions for "the safety and security of peacekeepers" priority. Indonesia also facilitated international co-operation on peace operations through the hosting and cohosting of a series of international forums, such as in 2019 the "Triangular Formula Meeting on Training, Capacity Building, Safety and Security and Performance of UN Peacekeeping" or the meeting on "Investing in Peace: Improving Safety and Security of UN Peacekeeping and an open debate on the Protection of Civilians in Armed Conflicts".

\subsubsection{Usefulness of TOSSD pillar II for Indonesia}

Indonesia is a strong advocate for global and regional sustainable development and the Government has also demonstrated the ability to take leadership on these issues. Indonesia was very active in the development of the SDGs and participated in the 2017 and 2019 National Voluntary Reviews. It showed leadership in international climate negotiations, for example with the organisation of the UNFCCC COP 13 in 2007 and the adoption of the Bali Road Map. It is also currently a member of the Paris Committee on Capacity-building which aims at providing capacity building for developing countries in undertaking their climate actions. On international peace and security, Indonesia is currently a member of the United Nations Security Council, where it has expressed its priorities, one of which is the need to foster the linkages between sustaining peace and sustaining development, particularly the 2030 Agenda (see section 7.2.3). Indonesia takes also a regional leadership role on sustainable development in particular through institutions such as the ASEAN or the United Nations Economic and Social Conference for Asia and the Pacific (UNESCAP), for example with the regional roadmap for implementing the 2030 Agenda for sustainable development in the Asia and Pacific ${ }^{115}$. Another example is the Coral Triangle Initiative on Coral Reefs, Fisheries, and Food Security (CTI-CFF) ${ }^{116}$ that was initiated by Indonesia. Finally, given its natural resources potential, Indonesia's voice on sustainable development matters resonates particularly well on the international stage.

The information gathered from the country mission and presented in this chapter shows that Indonesia allocates a significant part of its national budget towards activities that support SDG-relevant international public goods/global challenges (Research and Development, environmental protection, peace and security). Several stakeholders interviewed in Indonesia emphasised that, if TOSSD could provide transparency on these activities, it can be a strong tool supporting Indonesia's international policies and advocacy efforts. TOSSD would show the national and international public how Indonesia's national budget

\footnotetext{
114 See https://peacekeeping.un.org/sites/default/files/a4p-declaration-en.p xcdf

115 https://www.unescap.org/sites/default/files/publications/SDGs-Regional-Roadmap.pdf

116 The Coral Triangle Initiative on Coral Reefs, Fisheries, and Food Security (CTI-CFF) is a multilateral partnership of six countries working together to sustain extraordinary marine and coastal resources by addressing crucial issues such as food security, climate change and marine biodiversity.
} 
spending supports regional and global sustainable development. It would also show how Indonesia's national policies are aligned with its international commitments.

\subsection{Capacity of Indonesia to measure and report on public finance for international public goods}

\subsubsection{Research and development (R\&D)}

\section{Capacity to track and measure public finance for $R \& D$}

Data and statistics on public finance for R\&D exist in Indonesia. Several methods are used.

\section{Government Budget Appropriations or Outlays on Research \& Development (GBARD)}

The most comprehensive measure is the Government Budget Appropriations or Outlays on Research \& Development (GBARD), which is compiled based on the Frascati Manual guidelines. ${ }^{117}$ The GBARD data are compiled since 2017 by the Ministry of Research and Technology (MoRT). ${ }^{118}$ They are measured at the national budgeting level and are based on the identification of all the budget items that may support $R \& D$ activities and the measurement or estimation of their R\&D content. ${ }^{119}$ The GBARD measure covers spending allocations from the budgets of central and local governments, but also extra-budgetary government entities to the extent that their funds are allocated through the budgetary process. ${ }^{120}$ It also covers basic research, applied research and experimental development but these are not identified separately.

In 2018, GBARD in Indonesia amounted to USD 2 billion (IDR 29.8 trillion), representing $0.2 \%$ of its GDP, with USD 1.99 billion (IDR 28.9 trillion) from the central government budget and USD 61.5 million (IDR 890 billion) from the budgets of local governments. GBARD data from the central government are compiled for all the R\&D Units in all Ministries and Non-Ministerial Government Research Institutions (GRI-NMs). Information on the R\&D sector is not available in the GBARD data compiled in Indonesia, although the Frascati manual guidelines do allow the compilation of statistics by sector. In addition to the distribution of GBARD by R\&D-Ms and GRI-NMs, a breakdown is provided for the following five categories:

- R\&D activities.

- Science and Technology Services: science and technology information services; data collection (expedition, species identification); conservation, testing \& standardisation; patent \& licence work; dissemination of $R \& D$ results.

- Training and education.

\footnotetext{
117 The Frascati manual is the international reference guide for collecting and reporting data on research and experimental development https://www.oecd.org/sti/inno/frascati-manual.htm.

118 The MoRT carries out a broader estimation of Gross Expenditures on Research and Development (GERD) based on the Frascati manual methodology. GERD statistics include R\&D spending from the government budget, the budget of universities, excluding allocations from government budget, and private funds. However, detailed data are only available for GBARD.

119 See chapter 12 of the Frascati manual 2015 for more information on the compilation of GBARD statistics https://read.oecd-ilibrary.org/science-and-technology/frascati-manual-2015/government-budget-allocations-for-ramp-d 9789264239012-14-en\#page1
}

${ }^{120}$ R\&D funding provided by public enterprises is outside the scope of GBARD statistics as this funding is raised from the market and outside the budgetary process. 
- Operational costs: employee salaries, R\&D operations.

- Capital budget: equipment and laboratory buildings.

The main limitation of the GBARD data is that they are too aggregated for the purposes of TOSSD. Given that they are derived from budget allocations of the central and local governments, the level of detail available does not allow to identify the ultimate use of the funds and verify whether activities comply with the TOSSD eligibility criteria. GBARD statistics are used in this report as an indication of Indonesia's aggregate support for R\&D.

\section{The Research \& Development (R\&D) survey}

In addition to the GBARD data, the MoRT carries out an R\&D survey through a questionnaire that is sent to all the R\&D Units in all Ministries and Non-Ministerial Government Research Institutions (GRI-NMs). The questionnaire includes information on the sector and type of R\&D (basic research, applied research or experimental development). However, given the usually low response rate ${ }^{121}$, the data are subject to quality issues. A challenge mentioned during the country mission is the lack of a legal framework that would make the response to the questionnaire mandatory for all the institutions surveyed.

\section{Activity-level data}

TOSSD is based on project-level data. Data on publicly-funded R\&D projects are managed by the Ministry of Research and Technology (MoRT). Several data management systems exist. R\&D activities funded from the budget of the MoRT and the National Research and Innovation Agency, in general through calls for projects (e.g. the Higher Education Research Funds - BOPTN), are managed and monitored through Simlitabmas, ${ }^{122}$ the "Information system for research management and community development". In addition since 2018 , in order to monitor the implementation of publicly-funded $R \& D$, a presidential decree and a MoRT regulation ${ }^{123}$ request other ministries and entities which receive an R\&D envelope from the State budget to report on their R\&D activities to the MoRT annually, and to the President of the Republic of Indonesia every five years. However, the Government encountered difficulties in the implementation of the presidential decree. The PRN 2020-2024 confirmed the obligation for all ministries that have an R\&D budget to report on their R\&D activities. The type of information collected include the name of the implementing institution, the name of the researcher, the budget allocated to the research activity, the names of the partners, the expected output per year and the expected output at the end of the project. The data are collected through MONEV Risbang, ${ }^{124}$ a web-based data warehouse. MONEV Risbang is not open to the public and only registered users can access the research database.

\footnotetext{
121 The response rate is usually below $50 \%$.

122 See http://simlitabmas.ristekdikti.go.id/

${ }^{123}$ See presidential decree No.38/2018 and the MoRT Regulation No.40/2018 related to the National Research Priority (PRN) 2017-2019
}

\footnotetext{
124 MONEV Risbang is a web-based data warehouse and business intelligence service that aims at facilitating government and private sector decision-making on R\&D by providing an integrated information system for R\&D data collection, sharing and analysis (see https://monevrisbang.ristekbrin.go.id). More specifically, its four objectives are to: (1) search and explore research and development data conducted by research institutions in Indonesia (exploration); (2) monitor trends, distribution, strengths and research maps as a support in data-based decision making (analysis); (3) provide access to reports related to research and development achievements and performance (reporting), and; (4) bridge access and exchange of data with other information systems within the Ministry of Research, Technology and Higher Education (data synergy).
} 
The total R\&D budget disbursed by the MoRT in 2019 was IDR 1883 billion (around USD 133 million). This budget is transferred to the implementing institutions through three competitive grant schemes (see Table 10.1):

- Higher Education Research Funds (Bantuan Operational Perguruan Tinggi Negeri-Penelitian) which are transferred directly to the Higher Education Institution (HEI),

- National Research Incentive for Innovation (Insentif Sistem Inovasi Nasional), and

- Industrial Technology Development Program (Program Pengembangan Teknologi Industri).

Starting from 2020, a new research funding scheme, the National Research Priority Flagship 2020-2024, has been put in place. The new funding scheme becomes the primary focus of national R\&D budget allocations with the objective to have by the end of 2024 around 40 major innovation products.

Table 10.1. Research \& Development grants provided by the Ministry of Research and Technology in 2019

\begin{tabular}{|c|c|c|c|c|}
\hline Research Scheme & $\begin{array}{l}\text { Number of } \\
\text { Research Topics }\end{array}$ & $\begin{array}{l}\text { Number of Implementing } \\
\text { Agencies }\end{array}$ & $\begin{array}{l}\text { Disbursements } \\
\text { (IDR Million) }\end{array}$ & $\begin{array}{l}\text { Disbursements } \\
\text { (USD Million) }\end{array}$ \\
\hline $\begin{array}{l}\text { Higher Education Research Funds } \\
\text { (BOPTN) }\end{array}$ & 16121 & 1234 & 1290181 & 91.3 \\
\hline Research for Capacity building & 851 & \multirow[t]{3}{*}{11} & 47527 & 3.4 \\
\hline Basic Research & 1617 & & 214689 & 15.2 \\
\hline Applied Research & 1003 & & 169585 & 12 \\
\hline $\begin{array}{l}\text { Higher Education Research } \\
\text { Consortium }\end{array}$ & 16 & \multirow[t]{3}{*}{1223} & 4844 & 0.3 \\
\hline World Class Research & 48 & & 6904 & 0.5 \\
\hline Other & 12586 & & 846632 & 59.9 \\
\hline $\begin{array}{l}\text { National Research Incentive for } \\
\text { Innovation (Insinas) }\end{array}$ & 65 & 52 & 84028 & 6 \\
\hline $\begin{array}{l}\text { Industrial } \quad \text { Technology } \\
\text { Development Program (PPTI) }\end{array}$ & 150 & 71 & 459041 & 32.5 \\
\hline Total & 16336 & & 1833250 & 130 \\
\hline
\end{tabular}

Source: Ministry of Research, Technology, DG of R\&D Strengthening, 2020

The main challenges faced by the Government in data collection on R\&D projects were:

- The insufficient level of reporting by the Research and Development Units in all Ministries and NonMinisterial Government Research Institutions (GRI-NMs) on the ultimate use of R\&D budget allocations they receive from the central government.

- The information gap that exists on private finance for R\&D, including philanthropy.

\section{Capacity of Indonesia to report on R\&D expenditures in TOSSD Pillar II}

Several stakeholders interviewed recognised the benefits of providing transparency, through TOSSD Pillar II, on national efforts supporting R\&D on transnational sustainable development issues. Transparency on R\&D projects that are ultimately supported by public funds would allow the Government to make more informed decisions on the allocation of R\&D resources and invest more strategically in R\&D. It would also enable the Government to better communicate, for example through TOSSD, on the efforts it is undertaking for $R \& D$, which is key for building public trust in this spending.

TOSSD is based on project-level data. The Ministry of Research and Technology (MoRT) is in charge of collecting data on R\&D projects funded by the Government. The recent regulations requesting the Research and Development Units in all Ministries and Non-Ministerial Government Research Institutions (GRI-NMs) to report on their activities to the Ministry of Research and Technology should improve the 
capacity of the Government to track public funding for $R \& D$ at activity-level. However, efforts could now focus on the implementation of these regulations as the in-country mission revealed that there can be issues relating to under reporting by government entities beyond the MoRT. Indonesia could explore the possibility to report these data in TOSSD, including information on the financing, the R\&D sector and a description of the project. Project-level data would allow the Secretariat to verify that the activities are aligned with the TOSSD eligibility criteria and demonstrate their international public good character.

\subsubsection{Environmental protection}

\section{Capacity to measure public finance for environmental protection}

Since 2016, Indonesia started to perform a Climate Budget Tagging (CBT) in order to track climaterelated expenditures in its national budget. The budget tagging system was developed with the support of UNDP with a broader objective of tracking sustainable development financing and improving the management of public domestic finance. ${ }^{125}$ CBT data are available since 2015 for climate mitigation and since 2018 for climate adaptation. The CBT data are quite disaggregated as they are compiled at the level of budget activities and outputs. A directorate in one ministry can have several activities and outputs. Examples of activities are "Implementation of Preservation and Capacity Building of National Roads" or "Development, Application and Supervision of Energy Conservation". Examples of outputs are "Forest and Land fire control" or "Road Maintenance". Finally, data are available both at the commitment (ceiling) and disbursement (realisation) level. Currently these data are disseminated only at aggregate level.

It is important to note that the national budget may include official grants and/or loans from external official sources, for example through budget support. According to Indonesian regulations, the Government can use foreign loans to finance the budget deficit or priority activities. ${ }^{126}$ However, although environmental protection is among the main priorities of the current National Medium Term Development Plan, the Government does not use foreign loans for environmental funding, and gives priority to foreign grants and innovative financing mechanisms. Still, foreign loans can indirectly finance environmental activities through general budget support ${ }^{127}$. Looking at the lesson learnt paper (which has similar text on page 44, section 5.4), I suggest to adjust as follows (i.e. text of the lessons learnt paper plus the last sentence of the above paragraph):

Given that the current budget tagging does not allow to differentiate the sources of financing (e.g. domestic taxation, external financing, etc.), there could be a case where budget support reported by external providers as a cross-border resource flow to Indonesia in pillar I serves to fund domestic climate mitigation expenditures reported by Indonesia in pillar II. In this case, adding up the two TOSSD pillars could lead to counting the same resource twice. However, the use of general budget support remains marginal in development co-operation, which is expected to be the case also for total TOSSD resources. The potential double-counting (only relevant in presentations of total TOSSD figures) should therefore not pose a major problem but merits to be regularly monitored. Should the volumes of general budget support

\footnotetext{
125 https://www.undp.org/content/undp/en/home/blog/2018/Indonesias-green-sukuk.html

126 The use of foreign loans in Indonesia is regulated by the Government regulation No. 10/2011 regarding Procurement Procedures of Foreign Loans and Grant Receipts, the Minister of PPN Regulation No.5/2011 regarding the Planning, Submission of Proposals, Assessment, Monitoring, and Evaluation of Activities Financed from Foreign Loans and Grants, and the current Medium National Development Plan (RPJMN).

127 General budget support consists of unearmarked contributions to the government budget. Budget support is a method of financing a recipient country's budget through a transfer of resources from an external financing agency to the recipient government's national treasury. The funds thus transferred are managed in accordance with the recipient's budgetary procedures.
} 
increase, the TOSSD Task Force should discuss whether any further analysis would need to be conducted on this issue.

In order to further enhance its capacity to monitor climate-related expenditures, Indonesia is planning to extend the CBT exercise to the sub-national governments and develop a methodology for measuring the impact of these expenditures.

Regarding biodiversity, there is no tracking system in place and estimations are made manually at aggregate level. There might be some double counting between climate adaptation and biodiversity data given that some expenditures address both issues.

\section{Capacity of Indonesia to report on climate expenditures}

In line with Indonesia's support for including domestic climate actions in TOSSD pillar II, the Government decided to report its climate mitigation expenditures in the 2019 TOSSD data survey on 2017 flows. Currently, Indonesia communicates only data aggregated at the level of line ministries (forestry, energy, waste, agriculture and industry). However, the Government is examining the possibility of providing more disaggregated data in TOSSD, ideally at the most disaggregated level, which is budget outputs. The 2017 data include, for example, information on 159 different budget outputs. This reporting would constitute a relatively small burden given that the data, as they are compiled today, are easily transferable in the TOSSD reporting form, including information on the commitment and disbursement amounts, the channel of delivery, a description, the modality, the TOSSD Pillar and the currency. The information on the sector and the SDG focus could be derived from the descriptions of the budget outputs. With support of the TOSSD Secretariat, Indonesia was able to report data on climate mitigation expenditures in the 2019 TOSSD data survey.

However, as discussed above the national budget may include resources raised from external sources, including from external official sources, for example through direct budget support. Given that the climate budget tagging does not currently allow to differentiate between these different sources of financing, there a risk of double counting budget support reported by TOSSD providers as a cross-border resource flow to Pillar I and domestic climate mitigation reported by Indonesia in pillar II. In order to avoid this double counting, the TOSSD Task Force should discuss what should be prioritised in such cases: the external cross-border resource flows or the domestic expenditure.

As explained in section 10.1.2, Indonesia supports also the inclusion of domestic expenditures climate adaptation expenditures in TOSSD Pillar II. Indonesia would have the capacity to also report on these expenditures.

As regards domestic expenditures in support of biodiversity, currently Indonesia can only report an annual aggregate figure. In order to have more disaggregated data the Government could consider extending the budget tagging system to biodiversity. It should be noted that the treatment of biodiversity in TOSSD has not yet been clarified by the TOSSD International Task Force.

\subsubsection{Peace and security}

Indonesia's contributions to peace and security that could be reported in TOSSD Pillar II are mainly related to international peace operations. Indonesia is a large troop and police contributor to UN peacekeeping. The expenditures that could be reported include the pre-deployment trainings carried out in the Peace Forces Training Centre and the additional expenditures incurred by Indonesia during the peacekeeping operations since the UN reimbursement does not fully cover the costs. The budget of the Peace Forces Training Centre is managed by the Ministry of Defence. The costs of deployment are managed by the Ministry of Defence and Polri (Indonesian National Police). Both these budgets are subject to confidentiality constraints and are currently not reportable in TOSSD. 
The Ministry of Foreign Affairs also carries out various political activities related to peace and security, mainly in the area of peacekeeping (see section 10.1.3). However, the budget system of the Ministry does not currently allow to extract the costs associated with these activities.

Indonesia could explore the possibility to disclose part or all of these costs in the future as this would recognise the important contributions made by Indonesia to international peace and security. 


\section{Conclusion and next steps}

The TOSSD pilot in Indonesia confirmed the usefulness of country pilots for testing the TOSSD methodology and for ensuring feedback by partner and provider countries on TOSSD as a measurement framework.

The full set of findings and recommendations of this pilot study can be found in Chapters 1 and 2 .

Following the TOSSD pilot, the Government of Indonesia decided to become a member of the international TOSSD Task Force. Indonesia, through the Ministry of National Development Planning/Bappenas, will now participate in all Task Force meetings and will be a key stakeholder in the development of the TOSSD measure. Indonesia will bring a particularly relevant perspective in the TOSSD discussions in areas such as environmental sustainability, peace and security, the measurement of South-South Co-operation and the importance of Islamic finance for sustainable development. It will also voice the concerns and expectations of the Asia-Pacific region, along with other countries from the region that are members of the Task Force (e.g. the Philippines and Timor Leste).

The recommendations formulated to the TOSSD Task Force in this report will be discussed at an upcoming Task Force meeting. As regards the recommendations formulated by the mission team to Indonesia, the TOSSD Secretariat stands ready to support the Government of Indonesia in implementing the TOSSD framework at the country level, particularly for setting up a process for collecting, compiling, and reporting TOSSD data. 
Annexes 


\section{Annex A. List of institutions visited during the in- country mission}

During the in-country mission, the study team visited the following institutions in Indonesia:

- Badan Amil Zakat National Agency (BAZNAS)

- Bank Indonesia

- Civil Society Organisations (Representatives of)

- Delegation of the European Union to Indonesia and Brunei Darussalam

- Development partners (meeting coordinated by the OECD Office in Indonesia)

- Indonesia Eximbank

- Filantropi Indonesia

- Financial Services Authority (OJK)

- Global Reporting Initiative (GRI)

- Islamic Development Bank

- Ministry of Finance (MOF)

- Ministry of Foreign Affairs (MOFA)

- Ministry of Law and Human Rights (Kemenkumham)

- Ministry of National Development Planning/National Development Planning Agency (Ministry of National Development Planning/Bappenas)

- Ministry of Research and Technology

- National SDGs Secretariat

- Statistics Indonesia (BPS)

- UN Global Compact Network Indonesia

- United Nations Development Programme Indonesia 


\section{References}

AidData (2017), AidData's Global Chinese Official Finance Dataset, 2000-2014, Version 1.0 (dataset accessed on 12 February 2020), https://www.aiddata.org/data/chinese-global-officialfinance-dataset.

AidData (n.d.), What does our China data cover? An open source approach sheds light on opaque financial flows (website accessed on 25 February 2020), https://www.aiddata.org/china-officialfinance.

Asian Development Bank; Islamic Development Bank (2019), The Evolution of Indonesia's Participation in Global Value Chains, http://dx.doi.org/DOI: http://dx.doi.org/10.22617/SPR190493-2.

Bank Indonesia (n.d.), Indonesian Financial Statistics, https://www.bi.go.id/en/statistik/seki/terkini/eksternal/Contents/Default.aspx.

Bank Indonesia (n.d.), Indonesian Financial Statistics (website accessed on 26 February 2020), https://www.bi.go.id/en/statistik/seki/terkini/eksternal/Contents/Default.aspx.

Bejraoui, A. and J. Benn (2019), Research, science, technology and innovation in TOSSD, TOSSD Task Force issues paper, http://www.oecd.org/dac/financing-sustainabledevelopment/development-finance-standards/Research-Science-Innovation-item7.pdf.

Benn, J., C. Sangaré and T. Hos (2017), "Amounts Mobilised from the Private Sector by Official Development Finance Interventions", OECD Development Co-operation Working Papers No. 36, https://doi.org/10.1787/8135abde-en.

Benn, J., C. Sangaré and T. Hos (2017), Amounts Mobilised from the Private Sector by Official Development Finance Interventions. Guarantees, syndicated loans, shares in collective investment vehicles, direct investment in companies and credit lines, OECD, https://www.oecdilibrary.org/docserver/8135abdeen.pdf?expires $=1581512366 \&$ id $=i d \&$ accname $=0$ cid84004878\&checksum $=A F B 92 D C 2 D 93 E 443$ 5B102E5E695BEE8B4.

Geospatial Information Agency of Indonesia (2017), Identification of Islands and Standardization of Their Names, https://unstats.un.org/unsd/geoinfo/UNGEGN/docs/11th-uncsgndocs/E Conf.105 115 CRP.115 9 Identification\%20of\%20Islands\%20and\%20Standardization \%20of\%20Their\%20Names BIG Indonesia.pdf.

Ginting, E., C. Manning and K. Taniguchi (eds.) (2018), Education, Skills, and Labor Productivity, Asian Development Bank, http://dx.doi.org/10.22617/TCS189213-2. 
Global Reporting Initiative (n.d.), About GRI (website accessed 26 February 2020), https://www.globalreporting.org/information/about-gri/Pages/default.aspx.

Gol (2019), Roadmap of SDGs Indonesia, Toward 2030, https://drive.google.com/file/d/1SnQY t52KZaEVub8U6JEh1rSL BhrY3b/view.

Gol (2019), Voluntary National Reviews - Empowering People and Ensuring Inclusiveness and Equality, Republic of Indonesia, Jakarta, Indonesia, https://sustainabledevelopment.un.org/content/documents/2380320190708 Final VNR 2019 I ndonesia Rev3.pdf.

Gol (2018), Government regulation of the republic of indonesia - number 48 of 2018 about procedures for giving grant to foreign governments / foreign institutions, https://sipuu.setkab.go.id/PUUdoc/175669/PP\%20Nomor\%2048\%20Tahun\%202018.pdf.

Gol (2017), Third National Communication under the United Nations Framework Convention on Climate Change, https://unfccc.int/sites/default/files/resource/8360571 Indonesia-NC3-2Third\%20National\%20Communication\%20-\%20Indonesia\%20\%20editorial\%20refinement\%2013022018.pdf.

Gol (2017), Voluntary National Review (VNR). "Eradicating poverty and promoting prosperity in a changing world", Republic of Indonesia, Jakarta, Indonesia, https://sustainabledevelopment.un.org/content/documents/15705Indonesia.pdf\#page=97\&zoom $=100,185,782$.

Gol (2016), Indonesia Biodiversity Strategy and Action Plan 2015-2020, https://www.cbd.int/doc/world/id/id-nbsap-v3-en.pdf.

Gol (2015), National Medium-Term Development Plan (RPJMN) 2015-2019 - Rencana Pembangunan Jangka Menengah Nasional (RPJMN) 2015-2019, BAPENNAS, https://www.bappenas.go.id/id/data-dan-informasi-utama/dokumen-perencanaan-danpelaksanaan/dokumen-rencana-pembangunan-nasional/rpjp-2005-2025/rpjmn-2015-2019/.

Gol (2011), Regulation of the Government of the Republic of Indonesia 10/2011 on Foreign Loans Procurement and Grants Receipts, https://www.kemenkeu.go.id/sites/default/files/pdfperaturan/15.pdf.

Gol (2007), Elucidation to Law of the Republic of Indonesia on the Long-term National Development Plan of 2005-2025, https://www.bappenas.go.id/files/6715/3173/4665/RPJPN 2005-2025.pdf.

Gol (2007), Law of the republic of indonesia number 17 of 2007 on long-term national development plan of 2005-2025, https://www.bappenas.go.id/files/6715/3173/4665/RPJPN 2005-2025.pdf.

Gol (2004), Law 25 of 2004 on the National Development Planning System, http://birohukum.bappenas.go.id/data/data tematik/UU\%2025\%20Tahun\%202004\%20versi\%20 inggris.pdf.

IGES (2017), "Sustainable Development Goals Interlinkages and Network Analysis: A practical tool for SDG integration and policy coherence", https://sdginterlinkages.iges.jp/files/IGES Research\%20Report SDG\%20Interlinkages Printing \%20Version.pdf.

IMF (2019), "Indonesia : 2019 Article IV Consultation-Press Release; Staff Report; and Statement 
by the Executive Director for Indonesia", IMF Country Report No. 19/250, http://dx.doi.org/ISBN/ISSN:9781513509129/1934-7685.

IMF (2019), "World Economic Outlook Database", World Economic and Financial Surveys, https://www.imf.org/external/pubs/ft/weo/2019/01/weodata/index.aspx.

Indonesian Central Bureau of Statistics (2019), National Strategic Indicators, https://www.bps.go.id/QuickMap?id=0000000000.

International TOSSD Task Force (2019), TOSSD Reporting Instructions - Version of 5 June 2019, http://www.oecd.org/dac/financing-sustainable-development/development-financestandards/TOSSD-Reporting-Instructions.pdf.

International Trade Centre UNCTAD/WTO (2019), "List of products at 2 and 4 digits level exported by Indonesia in 2018", Trade Map, https://www.trademap.org/Index.aspx?lang=fr.

Ministry of Foreign Affairs of the Republic of Indonesia (2019), Indonesian Membership on the UN Security Council (website accessed on 12 February 2020), https://kemlu.go.id/portal/en/read/147/halaman list lainnya/indonesian-membership-on-the-unsecurity-council.

Ministry of National Development Planning/Bappenas (2019), Roadmap of SDGs Indonesia, http://sdgs.bappenas.go.id/dokumen/.

Ministry of National Development Planning/Bappenas (2018), List of medium-term planned external loans 2015-2019, 2018 revision, https://www.bappenas.go.id/files/bluebook dan greenbook/DRPLNJM\%20(Blue\%20Book)\%20Revisi\%202018.pdf.

Ministry of National Development Planning/Bappenas (2018), List of planned priority external loans 2018, https://www.bappenas.go.id/files/bluebook dan greenbook/greenbook/Green-Book2018.pdf.

National Coordination Team of SSC (2018), Annual Report of Indonesia's South-South Cooperation: moving forward towards better SSC management 2017, Government of Indonesia, Jakarta, Indonesia.

National Coordination Team of SSC (2017), Annual Report ofIndonesia's South-South and Triangular Coorperation (SSTC) 2016, Indonesia, Jakarta, https://isstc.setneg.go.id/images/stories/newsletter/annual report sstc 2016.pdf.

National Coordination Team of SSTC (2016), Annual Report of Indonesia's South-South and Triangular Cooperation (SSTC) 2015, Jakarta, Indonesia, https://isstc.setneg.go.id/images/stories/newsletter/150816 asiapr annual report of indonesia s sstc 2015 english.pdf.

National Coordination team of SSTC (2015), Annual Report ofIndonesia'sSouth-South andTriangular Cooperation (SSTC) 2014, Jakarta, Indonesia, http://open jicareport.jica.go.jp/pdf/12315693.pdf.

OECD (2019), OECD Green Growth Policy Review of Indonesia 2019, OECD Environmental Performance Reviews, OECD Publishing, Paris, https://dx.doi.org/10.1787/1eee39bc-en. 
https://www.oecd.org/tax/tax-policy/revenue-statistics-asia-and-pacific-indonesia.pdf.

OECD (2019), Social Protection System Review of Indonesia, OECD Development Pathways, OECD Publishing, Paris, https://dx.doi.org/10.1787/788e9d71-en.

OECD (2019), Total Official Support for Sustainable Development (TOSSD) - A new statistical measure for the SDG era - 4 page flyer, http://www.oecd.org/dac/financing-sustainabledevelopment/development-finance-standards/TOSSD-A-New-Statistical-Measure-forthe\%20SDG-Era.pdf.

OECD (2018), "Estimates for other providers of development co-operation not reporting to OECD", in Development Co-operation Report 2018: Joining Forces to Leave No One Behind, OECD Publishing, Paris, https://doi.org/10.1787/dcr-2018-50-en.

OECD (2018), Global Outlook on Financing for Sustainable Development 2019: Time to Face the Challenge, OECD Publishing, Paris, https://dx.doi.org/10.1787/9789264307995-en.

OECD (2018), OECD Economic Surveys: Indonesia 2018, OECD Publishing, Paris, https://dx.doi.org/10.1787/eco surveys-idn-2018-en.

OECD (2018), Perspectives on Global Development 2019: Rethinking Development Strategies, OECD Publishing, Paris, https://dx.doi.org/10.1787/persp glob dev-2019-en.

OECD (2018), Tri Hita Karana Roadmap for Blended Finance, http://www.oecd.org/dac/financingsustainable-development/development-financetopics/ THK\%20Roadmap\%20booklet\%20A5.pdf.

OECD (2017), Results of the 2016 DAC Survey on mobilization, 2012-2015, USD million, https://public.tableau.com/views/Mobilisation3/Dashboard1?:embed=y\&:display count=yes\&:sh owTabs=y\&:toolbar=no?\&:showVizHome=no.

OECD (2017), Results of the 2016 DAC Survey on mobilization, 2012-2015, USD million (data visualisations tools accessed on 12 February 2020), https://public.tableau.com/views/Mobilisation3/Dashboard1?:embed=y\&:display count=yes\&:sh owTabs=y\&:toolbar=no?\&:showVizHome=no.

OECD (n.d.), Creditor Reporting System (CRS) and Other official flows (OOF) and export credits disbursements [DAC2b] (datasets accessed on 25 February 2020), https://stats.oecd.org/Index.aspx?DataSetCode=CRS1.

OECD (n.d.), OECD iLibrary (accessed on 6 March 2020), https://www.oecdilibrary.org/search?value $1=$ TOSSD\&option $1=$ quicksearch\&facetOptions $=51 \&$ facetNames=pub i gold facet\&operator51=AND\&option51=pub igold facet\&value51=\%27igo\%2Foecd\%27\&publi sherld=\%2Fcontent\%2Figo\%2Foecd\&searchType=quick.

OECD (n.d.), Private Philanthropy for Development (CRS) (dataset accessed on 24 February 2020), https://stats.oecd.org/Index.aspx?DataSetCode=CRS1.

OECD (n.d.), Private Philanthropy for Development (CRS) (dataset accessed on 25 February 2020), https://stats.oecd.org/Index.aspx?DataSetCode=CRS1.

OECD (n.d.), Total Official Support for Sustainable Development (TOSSD), http://www.oecd.org/dac/tossd/. 
accessed 27 February 2020), http://www.oecd.org/dac/financing-sustainabledevelopment/tossd.htm.

Presidential Regulation no. 59/2017 (2017), .

SDG Philanthropy Platform (n.d.), What we do (website accessed on 26 February 2020), https://www.sdgphilanthropy.org/About-SDGPP.

Statistics Indonesia (2019), Gini Ratio Provinsi 2002-2019, https://www.bps.go.id/dynamictable/2017/04/26/1116/gini-ratio-provinsi-2002-2019.html.

UN DESA (2019), "Total population (both sexes combined) by region, subregion and country, annually for 1950-2100 (thousands)", World Population Prospects 2019, Online Edition. Rev. 1, http://dx.doi.org/lGO: http://creativecommons.org/licenses/by/3.0/igo/.

UN DESA (2007), "Methodology sheets", Indicators of Sustainable Development Guidelines and Methodologies, https://www.un.org/esa/sustdev/natlinfo/indicators/methodology sheets.pdf.

UNDP (2019), Human Development Report 2019, http://www.hdr.undp.org/sites/default/files/hdr2019.pdf.

UNDP (2018), "Table 2. Human Development Index Trends, 1990-2017", Human Development Reports, http://hdr.undp.org/en/composite/trends.

UNDP (n.d.), Table 3: Inequality-adjusted Human Development Index (website accessed on 4 March 2020), http://hdr.undp.org/en/composite/IHDI.

Vujanovic, P. (2019), "Decentralisation to promote regional development in Indonesia", in Fiscal Decentralisation and Inclusive Growth in Asia, OECD Publishing, Paris, https://dx.doi.org/10.1787/600ec475-en.

White, H. (2018), Community-driven development: does it build social cohesion or infrastructure? A mixed-method evidence synthesis, 3ie Working Paper 30. New Delhi: International Initiative for Impact Evaluation (3ie), https://www.3ieimpact.org/sites/default/files/2019-01/wp30-cdd 0.pdf.

World Bank (2019), Age dependency ratio (\% of working-age population) - Indonesia, http://dx.doi.org/ID: SP.POP.DPND.

World Bank (2019), "Gross domestic product 2018”, World Development Indicators, https://datacatalog.worldbank.org/dataset/gdp-ranking.

World Bank (2019), Gross domestic product 2018, https://datacatalog.worldbank.org/dataset/gdpranking.

World Bank (2019), Indonesia Economic Quaterly, https://openknowledge.worldbank.org/bitstream/handle/10986/31993/Indonesia-EconomicQuarterly-Oceans-of-Opportunity.pdf?sequence=7\&isAllowed=y.

World Bank (2019), Poverty headcount ratio at $\$ 1.90$ a day (2011 PPP) (\% of population) Indonesia, https://data.worldbank.org/indicator/SI.POV.DDAY?locations=ID.

World Bank (2019), The World Bank in Indonesia (website accessed on 11 February 2020), https://www.worldbank.org/en/country/indonesia/overview.

World Bank (n.d.), Foreign direct investment, net inflows (BoP, current US\$) (website accessed on 
12 February 2020), https://data.worldbank.org/indicator/BX.KLT.DINV.CD.WD.

World Bank (n.d.), Personal remittances, received (\% of GDP) - Indonesia (website accessed on 12 [6 February 2020), https://data. worldbank.org/indicator/BX.TRF.PWKR.DT.GD.ZS?locations=ID\&view=chart.

World Bank (n.d.), Personal transfers, receipts (BoP, current US\$) - Indonesia (website accessed on 25 February 2020),

https://data.worldbank.org/indicator/BX.TRF.PWKR.CD?locations=ID\&most recent value desc =false \&view=chart.

World Economic Forum (2019), The Global Competitiveness Report 2019, http://www3.weforum.org/docs/WEF TheGlobalCompetitivenessReport2019.pdf.

World Economic Forum (2019), The Global Competitiveness Report 2019, http://www3.weforum.org/docs/WEF TheGlobalCompetitivenessReport2019.pdf. 


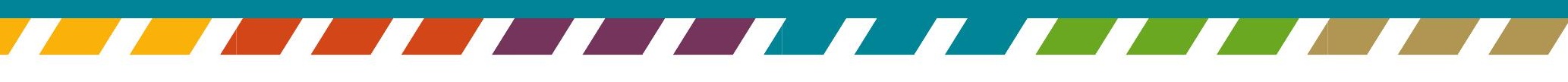

